UNIVERSIDADE DE SÃO PAULO

INSTITUTO DE GEOCIÊNCIAS

\title{
AVALIAÇÃO DE UM SISTEMA BIOELETROQUÍMICO (MFC - MICROBIAL FUEL CELL) COMO ALTERNATIVA PARA REMOÇÃO DE NITRATO EM ÁGUAS SUBTERRÂNEAS
}

Adriana Nakagama

Orientadora: Profa. Dra. Alexandra Vieira Suhogusoff

DISSERTAÇÃO DE MESTRADO

Programa de Pós-Graduação em Recursos Minerais e Hidrogeologia

São Paulo

2017 
UNIVERSIDADE DE SÃO PAULO

INSTITUTO DE GEOCIÊNCIAS

\section{AVALIAÇÃO DE UM SISTEMA BIOELETROQUÍMICO (MFC - MICROBIAL FUEL CELL) COMO ALTERNATIVA PARA REMOÇÃO DE NITRATO EM ÁGUAS SUBTERRÂNEAS}

Adriana Nakagama

Orientadora: Profa. Dra. Alexandra Vieira Suhogusoff

DISSERTAÇÃO DE MESTRADO

Programa de Pós-Graduação em Recursos Minerais e Hidrogeologia

São Paulo

2017 
Autorizo a reprodução e divulgação total ou parcial deste trabalho, por qualquer meio convencional ou eletrônico, para fins de estudo e pesquisa, desde que citada a fonte.

Ficha catalográfica preparada pelo Serviço de Biblioteca e Documentação do Instituto de Geociências da Universidade de São Paulo

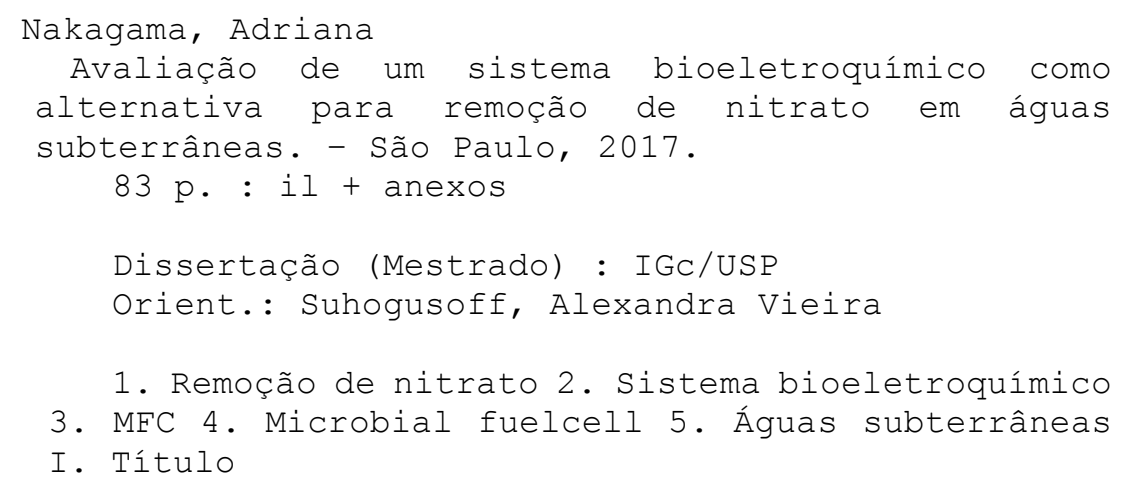


Dedico às minhas famílias de sangue e coração, Família Nakagama e Família Nagai, às minhas mães Natalia e Amélia, ao Di Mario e a meu namorado Benê. 
Que ninguém se engane, só se consegue a simplicidade através de muito trabalho.

Clarice Lispector 


\section{AGRADECIMENTOS}

À Prof. ${ }^{a}$ Dr. ${ }^{a}$ Alexandra Vieira Suhogusoff, pelas dicas, pela paciência e compreensão na orientação deste trabalho.

Ao Prof. Dr. Rodrigo de Freitas Bueno que sem sua dedicação e amor ao que faz, minha pesquisa não teria saído de maneira nenhuma do papel. Que acompanhou meus passos de perto, que por muitas vezes me auxiliou sem se importar se fosse aos finais de semana, feriado, noite ou dia.

Aos colegas e amigos do Laboratório de Saneamento da Poli-USP, em especial ao Fábio, Matheus e Marcel que além de abrir a porta do laboratório quando eu acabava ficando de fora, ainda me ajudaram muito nas coletas horarias.

Ao pesquisador Luewton Lemos do WETSUS (European Centre of Excellence for Sustainable Water Technology) que mesmo que a parceria no projeto inicial não tenha dado certo me ajudou bastante a entender o processo bioeletroquímico quando eu não fazia ideia de que este existia.

Aos fornecedores da membrana de troca iônica (Membranes International Inc) pelo envio gratuito da mesma.

À família e amigos pela compreensão da minha ausência, pelo apoio mesmo sem entender uma palavra sobre a minha explicação da pesquisa. Ao meu namorado, que no momento de desespero foi meu auxiliar de laboratório, motorista, psicólogo e porto seguro.

Ao professor Hirata, por ter ajudado a convencer a Alexandra a me aceitar como orientanda. 


\section{RESUMO}

NAKAGAMA, Adriana Yukie Tomita. (2017). Avaliação de um Sistema Bioeletroquímico (MFC Microbial Fuel Cell) como Alternativa para Remoção de Nitrato em Águas Subterrâneas. Dissertação (mestrado). Instituto de Geociências, Universidade de São Paulo, São Paulo.

O nitrato nas águas subterrâneas é considerado um dos principais problemas com relação aos padrões de potabilidade estabelecidos pela Portaria MS n² 2914/2011, o limite é de $10 \mathrm{mg} \mathrm{N}$ $\mathrm{NO}_{3} / \mathrm{L}$, tendo em vista que a ingestão de altas concentrações de nitrato está associada a doenças como câncer e a metahemoglobinemia. As preocupações com o nitrato devem-se as concentrações insidiosas e persistentes deste íon registradas pela CETESB desde o início do monitoramento das águas subterrâneas em 1990.

O presente trabalho propôs a avaliação de um processo alternativo para remoção de nitrato, trata-se de um sistema bioeletroquímico, também conhecido como MFC (Microbial Fuel Cells), que utiliza microrganismos para desnitrificação. Esse tratamento consiste no uso de processos biológicos potencializados pelo processo de eletrólise, aproveitando desta forma, os principais pontos característicos de cada processo de maneira combinada.

O sistema foi testado em escala de bancada, e consiste basicamente em uma câmara anódica onde ocorre a oxidação da matéria orgânica e uma câmara catódica onde ocorre o processo de redução do nitrato a $\mathrm{N}_{2}$. Entre as câmaras é utilizada uma membrana de troca iônica de forma a permitir somente a passagem de prótons da câmara anódica para a catódica, além de impedir a difusão de oxigênio para a câmara catódica. $O$ experimento realizou 8 testes variando a taxa de aplicação total de 2,88 a 11,52 L/dia com uma concentração $15 \mathrm{mg} \mathrm{N}-\mathrm{NO}_{3}{ }^{-} / \mathrm{L}$. Nos últimos dois testes ainda foi aplicada uma tensão externa. $O$ sistema atingiu uma eficiência média de remoção de nitrato de $80,84 \pm 16,73 \%$. As concentrações finais de nitrato permaneceram dentro dos padrões de potabilidade, com valor médio de 1,88 $\pm 2,03 \mathrm{mg} \mathrm{N}-\mathrm{NO}_{3}{ }^{-} / \mathrm{L}$, obtendo-se uma taxa de desnitrificação de $0,0498 \pm 0,03 \mathrm{~kg} / \mathrm{m}^{3}$.dia. $O$ acúmulo de nitrito no sistema teve valor médio de

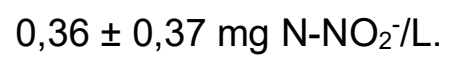

Palavras-Chave: remoção de nitrato; sistema bioeletroquímico; MFC; Microbial Fuel Cell; águas subterrâneas. 


\section{ABSTRACT}

NAKAGAMA, Adriana Yukie Tomita. (2017). Evaluation of a Bioelectrochemical System (MFC Microbial Fuel Cell) as an Alternative for the Removal of Nitrate in Groundwater. Master's Thesis. Instituto de Geociências, Universidade de São Paulo, São Paulo.

Nitrate in groundwater is considered to be one of the main problems with regard to the potability standards established by Ordinance MS $\mathrm{n}^{\circ} 2914 / 2011$, the limit is $10{\mathrm{mg} \mathrm{N}-\mathrm{NO}_{3}}^{-} / \mathrm{L}$, considering that the intake of high concentrations of nitrate Is associated with diseases such as cancer and methemoglobinemia. Concerns with nitrate are due to the insidious and persistent concentrations of this ion recorded by CETESB since the beginning of groundwater monitoring in 1990.

The present work proposed the evaluation of an alternative process for nitrate removal. This is a bioelectrochemical system, also known as MFC (Microbial Fuel Cells), which uses microorganisms for denitrification. This treatment consists in the use of biological processes potentiated by the electrolysis process, thus taking advantage of the main characteristic points of each process in a combined manner.

The system was tested on a bench scale, and basically consists of an anodic chamber where the oxidation of organic matter occurs and a cathodic chamber where the process of nitrate reduction to $N_{2}$ occurs. Between the chambers an ion exchange membrane is used in order to allow only the passage of protons from the anode chamber to the cathodic, in addition to preventing the diffusion of oxygen to the cathodic chamber. The experiment performed 8 tests varying the total application rate from 2.88 to $11.52 \mathrm{~L} / \mathrm{d}$ with a concentration of $15 \mathrm{mg} \mathrm{N}-\mathrm{NO}_{3}{ }^{-} / \mathrm{L}$. In the last two tests an external voltage was still applied. The system achieved an average nitrate removal efficiency of $80.84 \pm 16.73 \%$. The final concentrations of nitrate remained within the potability

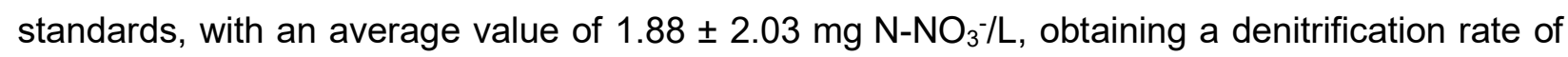
$0.0498 \pm 0.03 \mathrm{~kg} / \mathrm{m}^{3}$.d. The accumulation of nitrite in the system had an average value of $0.36 \pm$

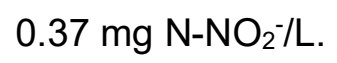

Keywords: nitrate removal; bioelectrochemical system; MFC; Microbial Fuel Cell; groundwater. 


\section{LISTA DE FIGURAS}

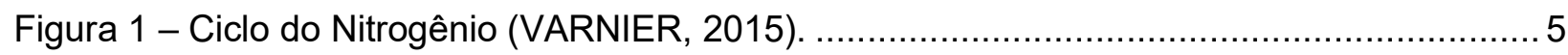

Figura 2 - Box-and-whisker - Nitrogênio nitrato 2013 a 2015 (CETESB, 2016)...................... 8

Figura 3 - Variação do número da transferência de elétrons de nitrogênio nos processos de nitrificação e desnitrificação (Adaptado, VAN HAANDEL; MARAIS, 1999)............................. 10

Figura 4 - Tipos de membranas e materiais retidos (Adaptado, PEARSON, 2015)................ 11

Figura 5 - Processo de troca iônica (MIERZWA, 2011) ..................................................... 12

Figura 6 - Processo de eletrodiálise (MIERZWA, 2011) ............................................... 13

Figura 7 - Regeneração da membrana de troca iônica através de bicarbonato seguindo para reator de desnitrificação (HOEK; KLAPWIJK, 1987) ........................................................ 16

Figura 8 - Sistema bioeletroquímico (Adaptado, BOROLE et al., 2011)............................... 17

Figura 9 - Princípios básicos de típicos processos bioeletroquímicos (WANG e REN, 2013). . 20

Figura 10 - Diferentes tipos de ligações da membrana de troca iônica em MFCs (Adaptado,

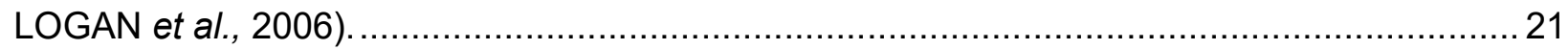

Figura 11 - Diferentes tipos de layouts de MFCs (LOGAN et al., 2006)................................ 22

Figura 12 - Representação esquemática do sistema bioeletroquímico (Elaborada pela autora).

Figura 13 - Arranjos de sistemas bioeletroquímicos para remoção de nitrato. ........................27

Figura 14 - (A) Representação esquemática do sistema bioeletroquímico; (B) Detalhes dos componentes.

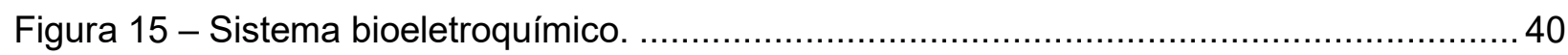

Figura 16 -Diagrama Boxplot para temperatura...................................................... 46

Figura 17 - Série temporal para temperatura....................................................... 46

Figura 18 - Variação do $\mathrm{pH}$, considerando todos os testes e Diagrama Boxplot - $\mathrm{pH}$............. 47

Figura 19 - Série temporal com médias móveis de 4 termos $-\mathrm{pH}$..................................... 47

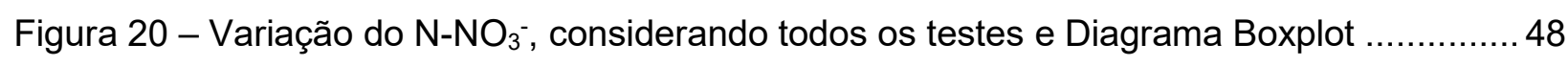

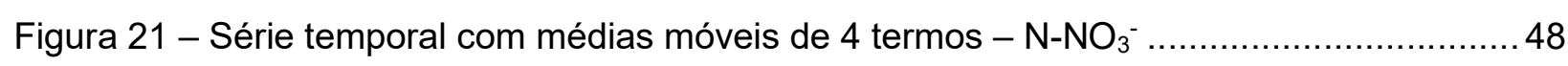

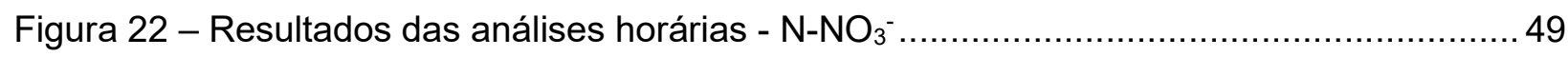

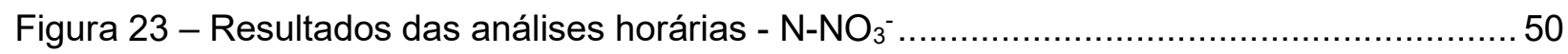

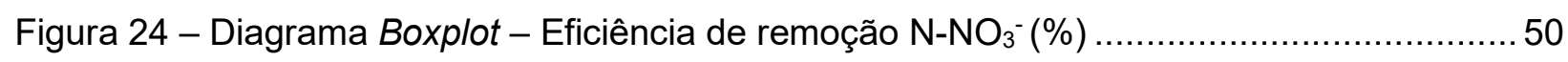

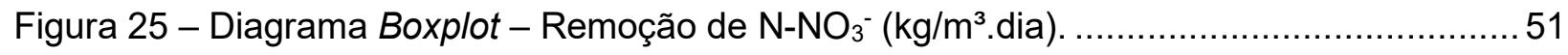

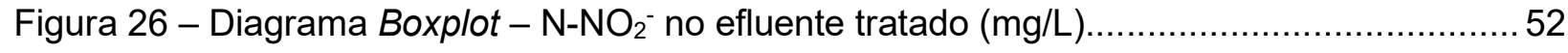

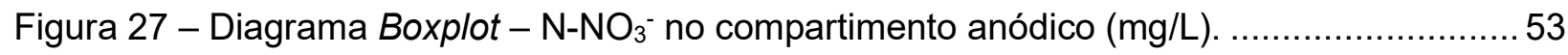

Figura 28 - Remoção de nitrato x Alcalinidade ........................................................... 54

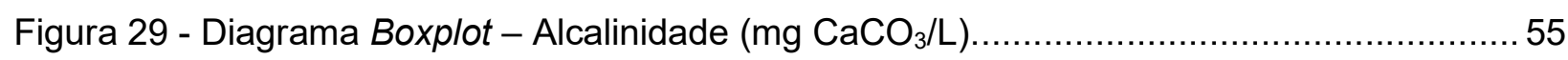

Figura 30 - Remoção de nitrato x Condutividade elétrica.............................................. 56 


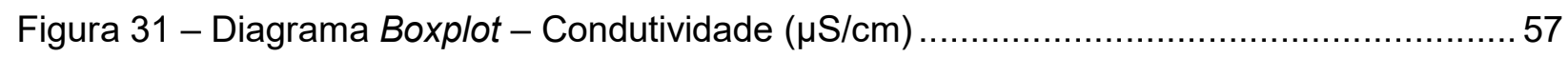

Figura 32 - Crescimento bacteriano no sistema bioeletroquímico ....................................... 58

Figura 33 - Diagrama Boxplot - Eficiência de Coulomb (\%) ............................................ 59

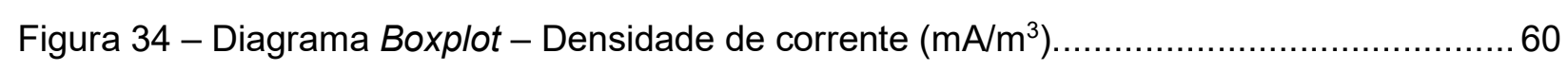

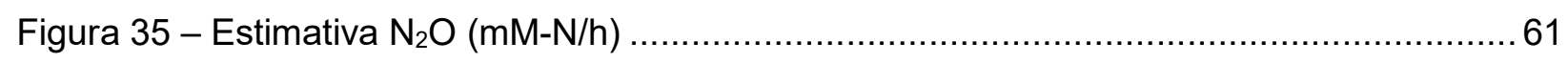




\section{LISTA DE TABELAS}

Tabela 1 - Compostos nitrogenados e seus números de oxidação.

Tabela 2 - Pontos de monitoramento com $\mathrm{N}^{-\mathrm{NO}_{3}}{ }^{-}$acima dos padrões de potabilidade em campanhas realizadas de 2013 a 2015 (CETESB, 2015). 9

Tabela 3 - Componentes básicos para um sistema bioeletroquímico 18

Tabela 4 - Microrganismos que podem gerar energia (LOGAN, 2009). 23

Tabela 5 - Relação de alguns substratos utilizados em sistemas bioeletroquímicos e respectivas densidades de corrente (Adaptado, PANT et al., 2009)...... 25

Tabela 6 - Síntese de resultados obtidos com sistemas bioeletroquímicos para remoção de nitrato. .29

Tabela 7 - Membranas de troca iônica utilizadas para tratamento de nitrato. 32

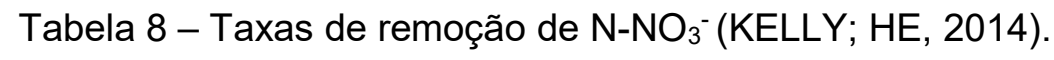
34

Tabela 9 - Composição da solução sintética injetada no cátodo. 41

Tabela 10 - Composição da solução de fonte de carbono injetada do ânodo. 41

Tabela 11 - Parâmetros de controle para o sistema bioeletroquímico. 42

Tabela 12 - Resumo das condições da investigação experimental. 42

Tabela 13 - Análises laboratoriais realizadas 44

Tabela 14 - Estatística da eficiência de remoção de $\mathrm{N}_{-} \mathrm{NO}_{3}{ }^{-}$(\%) para cada teste. .50

Tabela 15 - Remoção de $\mathrm{N}-\mathrm{NO}_{3}{ }^{-}\left(\mathrm{kg} / \mathrm{m}^{3}\right.$.dia) 51

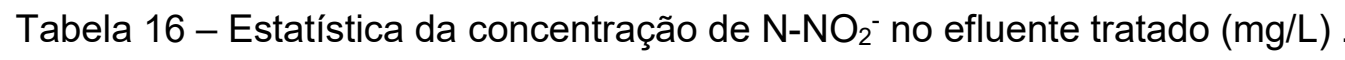
.52

Tabela 17 - Medições de $\mathrm{N}-\mathrm{NO}_{3}{ }^{-}$no compartimento anódico. .53

Tabela 18 - Alcalinidade ( $\mathrm{mg} \mathrm{CaCO}_{3} / \mathrm{L}$ ) medida nos testes. .54

Tabela 19 - Estatística da condutividade elétrica $(\mu \mathrm{S} / \mathrm{cm})$ para os testes realizados. .56

Tabela 20 - Estatística da Eficiência de Coulomb (\%) para os testes realizados .59

Tabela 21 - Estatística da Densidade de corrente $\left(\mathrm{mA} / \mathrm{m}^{3}\right)$ para os testes realizados 60 


\section{SUMÁRIO}

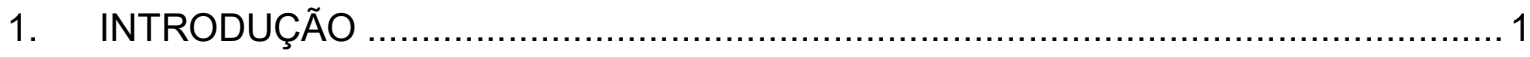

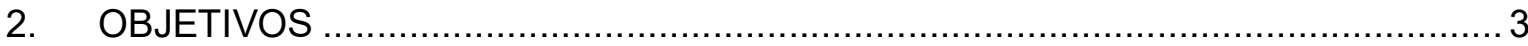

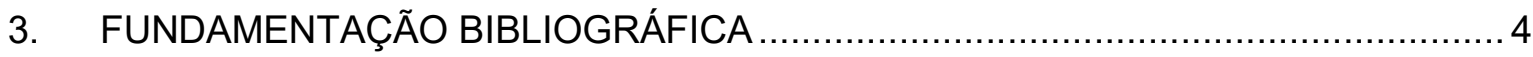

3.1 Ciclo do nitrogênio e o nitrato .................................................................... 4

3.1.1 Concentrações de nitrato no estado de São Paulo....................................... 7

3.2 Estequiometria das reações do nitrato .................................................... 9

3.2.1 Variação da alcalinidade no processo de desnitrificação................................ 9

3.2.2 Transferência de elétrons no processo de desnitrificação ............................10

3.3 Tratamentos existentes para remoção de nitrato ........................................... 10

3.3.1 Processos físico-químicos.................................................................... 10

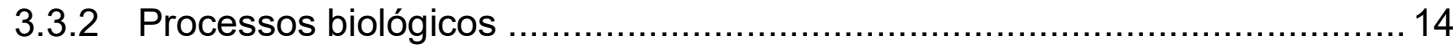

3.3.3 Processos bioeletroquímicos.............................................................. 16

3.3.4 Aplicação de sistemas bioeletroquímicos para remoção de nitrato ...............26

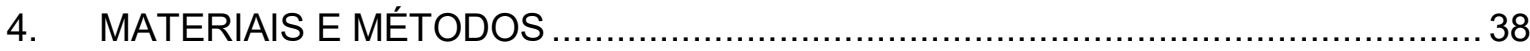

4.1 Descrição do sistema bioeletroquímico................................................... 38

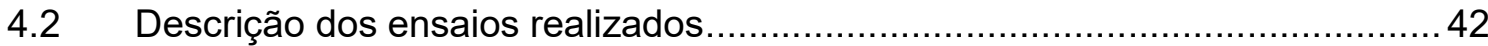

4.3 Metodologia de avaliação do experimento ....................................................... 43

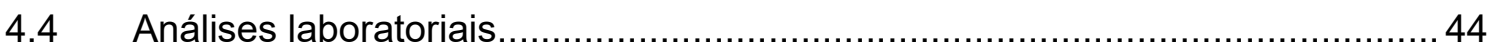

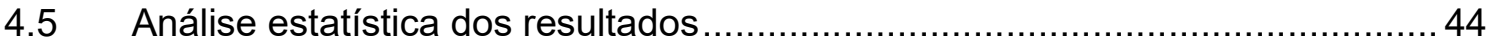

5. APRESENTAÇÃO E DISCUSSÃO DOS RESULTADOS .................................... 46

5.1 Resultados do controle do processo ........................................................ 46

5.2 Eficiência de remoção de nitrato............................................................... 47

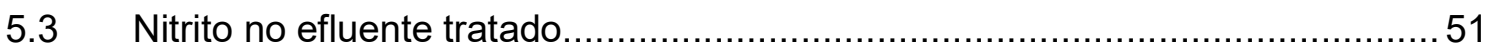

$5.4 \quad$ Nitrato no compartimento anódico ............................................................. 52

5.5 Relação Alcalinidade x Remoção de Nitrato ................................................ 53

5.6 Condutividade elétrica no processo bioeletroquímico …................................. 55

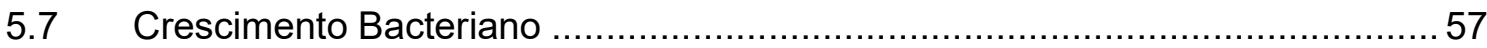

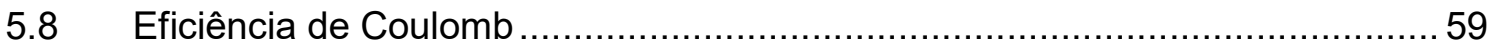




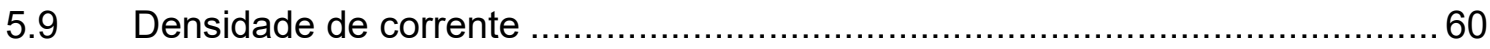

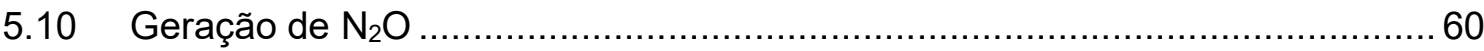

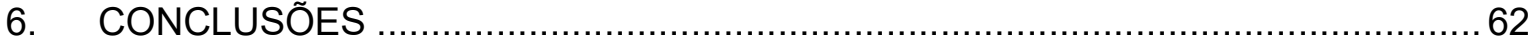

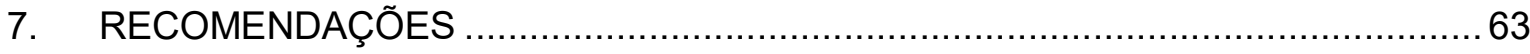

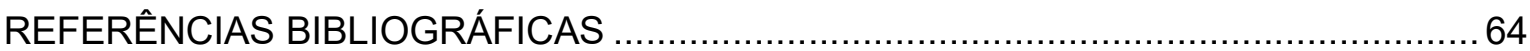

ANEXO I - Especificações Técnicas da Membrana de Troca iônica ............................... 70

ANEXO II - Resultados das análises laboratoriais ..................................................... 72 


\section{INTRODUÇÃO}

O nitrato é considerado pela Agência de Proteção Ambiental dos Estados Unidos (USEPA, 2002) um indicador de contaminação devido à sua estabilidade e origem. No Brasil, a Portaria do Ministério da Saúde n 2914 de 12 de dezembro de 2011 determina concentrações máximas

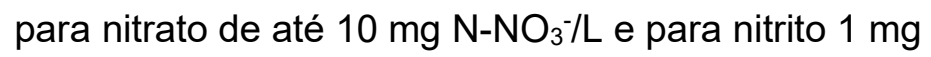

$\mathrm{N}-\mathrm{NO}_{2}-1 \mathrm{~L}$. Em águas subterrâneas, o nitrato também se destaca como contaminante inorgânico persistente de maior preocupação, visto sua relação com as atividades agropecuárias e com a contaminação antrópica decorrente da urbanização (FREEZE; CHERRY, 1979; OMS, 2011; ITRC, 2000; USEPA, 2002; RESENDE, 2002; MEURER, 2004; WARD et al., 2005; VARNIER et al., 2010; HYPOLITO et al., 2011). Dentre as fontes antrópicas que podem gerar contaminação por compostos nitrogenados, citam-se: percolação de efluentes por redes coletoras de esgoto, estações de tratamento, sistemas de saneamento in situ (fossas negras e sépticas), lixões e aterros mal construídos (sem impermeabilização de base) e vazamentos de substâncias tóxicas armazenadas em tanques aéreos ou subterrâneos (USEPA, 2002; HIRATA, 2012; IRITANI; EZAKI, 2009).

Segundo a Companhia Ambiental do Estado de São Paulo (CETESB) (1996), as concentrações naturais de nitrato nas águas subterrâneas no estado de São Paulo são em torno de $2,5 \mathrm{mg} \mathrm{N}-\mathrm{NO}_{3}{ }^{-} / \mathrm{L}$, entretanto a presença de nitrato tem sido registrada acima destes valores no Sistema Aquífero Bauru e no afloramento do Sistema Aquífero Guarani no noroeste do estado de São Paulo, desde o primeiro relatório publicado pela CETESB em 1996 com os resultados das campanhas realizadas de 1990 a 1994, além disso foi constatada a contaminação microbiológica, principalmente em poços instalados no Sistema Aquífero Bauru, indicando alteração da qualidade da água em função de atividade antrópica.

O último relatório publicado em 2016 com os resultados de 2013-2015 ainda apontava para a persistência da contaminação por nitrato nos pontos monitorados, embora com indicação de retração no número de poços com nitrato acima do padrão de potabilidade, o histórico de dados recorrentes mostram que o nitrato é um contaminante de grande dificuldade de remoção.

A presença de nitrato em concentrações superiores às consideradas como de referência de qualidade pela legislação apresenta riscos à saúde se houver ingestão, sendo a metahemoglobinemia ou síndrome do bebê azul a principal doença relacionada (CDC, 1998; ALABURDA; NISHIHARA, 1998; FEWTRELL, 2004; AVERY; L'HIRONDEL, 2003; MANASSARAM, 2010). O Instituto Nacional do Câncer (INCA, 2015) através de uma publicação sobre câncer no estômago também cita a relação da ingestão de água proveniente de poços com alta concentração de nitrato à maior incidência de tumores gástricos, Varnier (2001) cita o linfoma non-Hodgkin como um outro tipo de câncer que pode estar associado a ingestão de nitrato. 
Estudos realizados por Ward et al. (2005) citam que apesar do nitrato ser um composto estável no corpo humano, não pode ser metabolizado por suas enzimas tornando-se então inerte. No entanto, as reações de redução de nitrato através de bactérias comensais podem converter o nitrato a nitrito e outros compostos nitrogenados, que podem afetar processos fisiológicos e a saúde humana. Após a ingestão, já a partir do trato gastrointestinal superior e em outros locais, incluindo o intestino delgado e o cólon, o nitrato é reduzido a nitrito, o qual se combina com a hemoglobina, incapacitando-a de combinar-se com o oxigênio para transportá-lo aos tecidos do corpo humano (TAIZ; ZEIGER, 2009).

Tratamentos físico-químicos através de técnicas como osmose reversa, membranas de troca iônica, técnicas de eletrodiálise são convencionalmente aplicados na remoção de nitrato atualmente. Tais processos têm como principais desvantagens os custos atrelados e a criação de subprodutos. No entanto, tem-se destacado o emprego de sistemas bioeletroquímicos, também conhecidos como MFC (Microbial Fuel Cells), se aplicados apropriadamente, os produtos gerados corresponderiam apenas a água tratada e gás nitrogênio. Além disso, uma de suas principais características é a possibilidade de geração de energia elétrica. Ponderações quanto aos custos de implantação, manutenção e operação ainda estão em fase de estudos mais aprofundados (ZHANG; ANGELIDAKI, 2013; LEE et al., 2012).

Ainda não existem registros de que este sistema já foi testado no Brasil, e neste contexto, a pesquisa visa avaliar por meio de ensaios de bancada em laboratório a performance de um sistema bioeletroquímico para remoção de nitrato em água subterrânea preparada artificialmente, procurando analisar se o processo realmente atenua as concentrações de nitrato, se apresenta eficiência de remoção e se a desnitrificação de fato ocorreria a condições regionais (climáticas e materiais disponíveis) e se o processo teria potencial energético. Para tanto, foram quantificadas a eficiência de remoção de nitrato, a eficiência de Coulomb (parâmetro usualmente estimado em sistemas bioeletroquímicos para avaliação do processo) e a densidade de corrente, para estimativa da geração de energia. 


\section{OBJETIVOS}

O objetivo geral desse estudo consistiu em avaliar um sistema bioeletroquímico em escala de teste de bancada com materiais disponíveis no Brasil como alternativa para remoção de nitrato em águas subterrâneas.

Como objetivos específicos, listam-se:

- Investigar a eficiência do sistema na remoção do nitrogênio como nitrato $\left(\mathrm{N}^{-\mathrm{NO}_{3}}{ }^{-}\right)$a uma

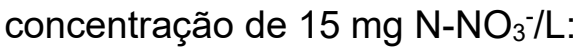

$\checkmark$ Através da variação da vazão de entrada no cátodo de $1 \mathrm{~mL} / \mathrm{min}, 2 \mathrm{~mL} / \mathrm{min}$ e $4 \mathrm{~mL} / \mathrm{min}$;

$\checkmark$ Através da variação da aplicação de fonte de energia externa no processo em 0V, $0,5 \mathrm{~V}$ e $1 \mathrm{~V}$.

- Quantificar a eficiência de Coulomb nos 8 cenários estudados;

- Quantificar a geração de energia do processo através da densidade de corrente nos 8 cenários estudados. 


\section{FUNDAMENTAÇÃO BIBLIOGRÁFICA}

A fundamentação bibliográfica visa embasar os estudos para implantação de um sistema bioeletroquímico como alternativa para remoção de nitrato em águas subterrâneas, abordando inicialmente a dinâmica e função do nitrato no meio ambiente, com ênfase nos processos de nitrificação e desnitrificação, bem como os processos e tecnologias usualmente empregadas para a remoção de nitrato, procurando enfatizar por fim, a tecnologia de tratamento escolhida como objeto do estudo.

\subsection{Ciclo do nitrogênio e o nitrato}

O nitrogênio $(\mathrm{N})$ é o constituinte mais abundante na atmosfera, representando $78 \%$ por volume (TAIZ; ZEIGER, 2009). É também um elemento químico essencial à formação de moléculas dos seres vivos fazendo parte da constituição da clorofila, de aminoácidos, peptídeos, proteínas, ácidos nucleicos (CAMPBELL; FARRELL, 2010). Nas plantas, apenas elementos como o oxigênio, o carbono e o hidrogênio são mais abundantes que o nitrogênio.

Além da forma orgânica, na natureza o $\mathrm{N}$ é encontrado como espécies inorgânicas em diferentes estados de oxidação (Tabela 1), desde sua forma mais reduzida, o amônio $\left(\mathrm{NH}_{3}\right)$, até sua forma mais oxidada, o nitrato $\left(\mathrm{NO}_{3}{ }^{-}\right)$. Em ambientes naturais, são esperadas baixas concentrações de $\mathrm{N}$ em solos e águas, em grande parte relacionadas à própria decomposição de matéria orgânica. Por outro lado, atividades antrópicas influenciam no ciclo do nitrogênio (Figura 1) podendo constituir fontes importantes de $\mathrm{N}$, dentre as quais citam-se as práticas agrícolas (com a aplicação de fertilizantes orgânicos e inorgânicos), pecuária (com a criação de animais em ambientes confinados), disposição de resíduos sólidos (em aterros e lixões) e sistemas de saneamento (p.e. vazamento em redes coletoras de esgoto, fossas sépticas e negras).

Tabela 1 - Compostos nitrogenados e seus números de oxidação.

\begin{tabular}{|c|c|c|c|c|c|c|c|c|}
\hline $\begin{array}{c}\mathrm{N}^{0} \text { de } \\
\text { oxidação }\end{array}$ & -3 & -3 & -2 & 0 & +1 & +2 & +3 & +5 \\
\hline & $\mathrm{NH}_{3}$ & $\mathrm{NH}_{4}^{+}$ & $\mathrm{N}_{2} \mathrm{H}_{4}$ & $\mathrm{~N}_{2}$ & $\mathrm{~N}_{2} \mathrm{O}$ & $\mathrm{NO}$ & $\mathrm{NO}_{2}^{-}$ & $\mathrm{NO}_{3}^{-}$ \\
\cline { 2 - 8 } & Amônia & Amônio & Hidrazina & Nitrogênio & $\begin{array}{c}\text { Óxido } \\
\text { nítrico }\end{array}$ & $\begin{array}{c}\text { Óxido } \\
\text { nitroso }\end{array}$ & Nitrito & Nitrato \\
\hline
\end{tabular}




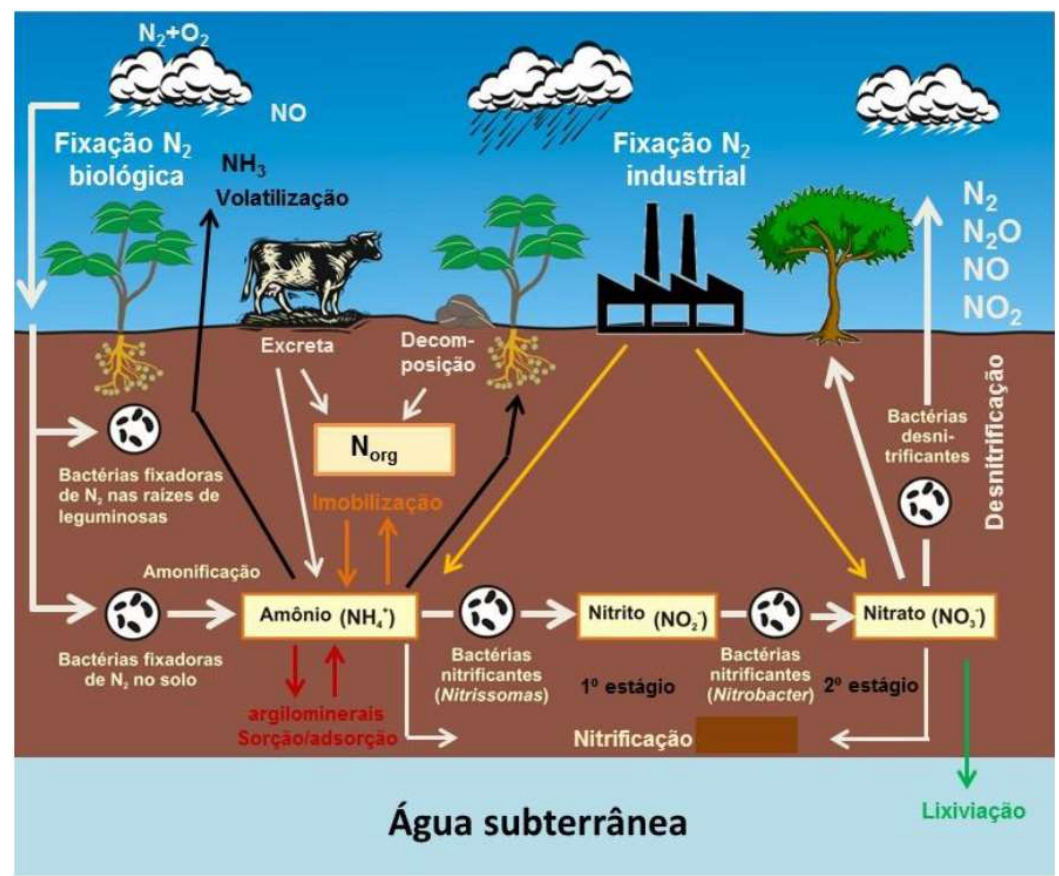

Figura 1 - Ciclo do Nitrogênio (VARNIER, 2015).

Pode se dizer que o ciclo do nitrogênio inicia-se pelo processo conhecido como fixação, que consiste na transformação do nitrogênio atmosférico para compostos nitrogenados (amônio e nitrato) que serão posteriormente assimilados pelas plantas (HYPOLITO et al., 2011). Apesar de abundante na atmosfera, animais e plantas não são capazes de metabolizar nitrogênio em sua forma gasosa. Existem três formas de fixação do nitrogênio: 1) fixação biológica, intermediada por bactérias na forma livre ou associadas a raízes de leguminosas e algas azuis, que dispõem da enzima nitrogenase responsável pela conversão; 2) fixação atmosférica, na qual descargas elétricas durante tempestades promovem a reação entre nitrogênio e oxigênio; e 3) fixação industrial (Haber-Bosch), processo em que gás nitrogênio é reagido com gás hidrogênio para produção de fertilizantes (SAWYER et al., 2003).

A amonificação ou mineralização é a conversão do nitrogênio orgânico (proteínas, aminoácidos, ureia, etc.) proveniente da decomposição de restos orgânicos em nitrogênio amoniacal (amônia e amônio) pela ação microbiológica (fungos e bactérias) (VARNIER, 2015). A volatilização, por sua vez, depende da reação de equilíbrio entre o gás amônia $\left(\mathrm{NH}_{3}\right)$ e o íon amônio $\left(\mathrm{NH}_{4}{ }^{+}\right)$em presença de água. A volatilização da amônia e seu escape para a atmosfera têm como mecanismos de controle as condições do meio, quais sejam $\mathrm{pH}$, temperatura e as concentrações de amônio (SAWYER et al., 2003). O amônio que se encontra disponível nas soluções dos solos também pode ser adsorvido em argilominerais a partir de processos de troca iônica ou sofrer oxidação biológica caso o meio seja aeróbio. Nesse último caso, a reação é conhecida como nitrificação, na qual o amônio que não sofreu adsorção é convertido a nitrito $\left(\mathrm{NO}_{2}{ }^{-}\right)$por intermédio de um grupo de bactérias aeróbias autotróficas chamadas Nitrosomonas (Equação 1) (MACLAREN; CAMERON, 1996) e, posteriormente, por sua vez o nitrito é oxidado a nitrato $\left(\mathrm{NO}_{3}{ }^{-}\right)$por outro grupo conhecido por Nitrobacter (Equação 2) (WILHELM et al., 1994). 


$$
\begin{gathered}
2 \mathrm{NH}_{4}^{+}+3 \mathrm{O}_{2}(\mathrm{~g}) \rightarrow 2 \mathrm{NO}_{2}+2 \mathrm{H}_{2} \mathrm{O}+4 \mathrm{H}^{+} \\
2 \mathrm{NO}_{2}^{-}+\mathrm{O}_{2}(\mathrm{~g}) \leftrightarrow 2 \mathrm{NO}_{3}^{-}
\end{gathered}
$$

Segundo Campos et al. (2007), as bactérias nitrificantes necessitam de concentrações de oxigênio dissolvido (OD) acima de $1 \mathrm{mg} \mathrm{O} / \mathrm{L}$. A velocidade de crescimento das bactérias Nitrobacter ocorre de maneira mais rápida do que a das bactérias Nitrosomonas, diferença considerada como limitante no processo de nitrificação (VAN HAANDEL; MARAIS, 1999).

Fechando o ciclo, tem-se a desnitrificação que corresponde à restituição do nitrogênio à atmosfera na forma molecular a partir da redução do nitrato pela ação de bactérias desnitrificantes (Equação 3) (WILHELM et al., 1994).

$$
4 \mathrm{NO}_{3}^{-}+5 \mathrm{CH}_{2} \mathrm{O}+4 \mathrm{H}^{+} \leftrightarrow 2 \mathrm{~N}_{2}+5 \mathrm{CO}_{2}+7 \mathrm{H}_{2} \mathrm{O} \quad \text { Equação } 3
$$

As bactérias desnitrificantes podem ser heterotróficas como as Pseudomonas, as quais necessitam de carbono orgânico como fonte de energia, ou autotróficas, como as Thiobacillus denitrificans e Thiomicrospira denitrificans, que se utilizam de compostos inorgânicos como bicarbonato, compostos de ferro ou enxofre para alcançar o mesmo fim (DARBI et al., 2002; GHAFARI et al., 2008; RIVETT et al., 2008).

Alguns fatores podem influenciar no processo de desnitrificação biológica, dentre os quais citam-se:

- Concentração de oxigênio: as bactérias presentes no meio natural seguem uma sequência termodinâmica para oxidação do carbono na zona saturada. O primeiro aceptor de elétrons é o oxigênio, quando este torna-se escasso as bactérias facultativas anaeróbias trocam o seu aceptor para o próximo na sequência, este seria o nitrato, em seguida o manganês, o ferro férrico, sulfato, metano e dióxido de carbono (RIVETT et al., 2008; CESARINO, 2002; CLARK; FRITZ, 1997). O oxigênio é o aceptor preponderante da sequência termodinâmica, de forma que altas concentrações podem inibir o processo de desnitrificação. A variação nos níveis de oxigênio pode interferir também na geração do produto final: observa-se que quando os níveis de oxigênio encontram-se baixos há a formação de $\mathrm{N}_{2}$ como produto final, porém se os níveis de oxigênio apresentarem variação ou concentrações intermediárias, as reações podem culminar com a formação de NOx (BRADY; WEIL, 2002). Os NOx são considerados gases de efeito estufa, possuindo aspecto ambientalmente negativo;

- Fontes de Carbono: conforme já mencionado, as bactérias heterotróficas necessitam de uma fonte carbono orgânico como doador de elétron na ausência de oxigênio. Tais bactérias utilizam o nitrato como aceptor de elétron, e uma fonte de carbono oxidável para reação (METCALF; EDDY, 2003):

$$
5 \mathrm{CH}_{3} \mathrm{OH}+6 \mathrm{NO}_{3}^{-} \rightarrow 3 \mathrm{~N}_{2}+5 \mathrm{CO}_{2}+7 \mathrm{H}_{2} \mathrm{O}+6 \mathrm{OH}^{-}
$$

Equação 4 
A disponibilidade dos compostos de carbono orgânico como doadores elétrons é um dos fatores mais importantes que controlam a atividade das bactérias heterotróficas, maioria dentre as desnitrificantes (KNOWLES, 1982). Segundo Mohseni-Bandpi et al. (2013), a dosagem insuficiente de doador de elétrons pode resultar em um elevado nível de nitrato e nitrito no efluente, e, por consequência, este requer um pós-tratamento.

- Concentrações de nitrato: embora o nitrato seja o contaminante alvo da remoção no processo, suas concentrações podem influenciar a taxa de crescimento das bactérias desnitrificantes, visto que estas utilizam o nitrito e o nitrato como receptores de elétrons (BITTON, 2005; CAMPOS et al., 2007). Segundo Campos et al. (2007), muitos processos de remoção de nitrato por vias biológicas podem falhar, devido à reação de nitrificação por bactérias autotróficas ser mais lenta. Beg et al. (1997) citam que o oxigênio é um fator limitante em processos que envolvem nitrificação e digestão de matéria orgânica no mesmo reator. Isto ocorre devido às altas concentrações de matéria orgânica fornecerem condições favoráveis para o desenvolvimento de bactérias heterotróficas que competem por oxigênio e nutrientes com as bactérias nitrificantes, que são autotróficas;

- $\quad$ pH entre 7 e 9: segundo Henze (2002) e Campos et al. (2007), tais valores apresentam condições mais favoráveis à desnitrificação. $\mathrm{O}$ pH tende a aumentar como resultado do consumo de íons $\mathrm{H}^{+}$do meio com o decorrer da desnitrificação, visto que a cada $1 \mathrm{mg}$ de nitrato que é reduzido a $\mathrm{N}_{2}$ produz-se $3,57 \mathrm{mg}$ de alcalinidade como $\mathrm{CaCO}_{3}(\mathrm{OLIVEIRA}, 2012)$;

- Temperatura: segundo Henze (2002), a desnitrificação biológica ocorre na faixa de $22^{\circ} \mathrm{C}$ a $40^{\circ} \mathrm{C}$, além disso a faixa ideal seria entre $32^{\circ} \mathrm{C}$ e $40^{\circ} \mathrm{C}$;

- Inibidores: a desnitrificação pode estar suscetível à inibição por uma variedade de compostos como o acetileno, azida, cianeto, 2,4-Dinitrophenol (DNP), nitrapirina, pesticidas, compostos de enxofre (KNOWLES, 1982). Segundo Knowles (1982), o mecanismo de ação não é claro para qualquer um dos inibidores, visto que estes exercem outros efeitos metabólicos além dos processos de reductase específicos envolvidos na desnitrificação.

Em consequência do uso excessivo de fertilizantes industriais utilizados na agricultura e demais fontes de nitrato já citadas, a desnitrificação é um importante processo do ciclo do nitrogênio para regular o acúmulo de nitrato não assimilado pelas plantas.

\subsubsection{Concentrações de nitrato no estado de São Paulo}

A CETESB, no estado de São Paulo monitora através de 288 pontos, a qualidade das águas subterrâneas e publica a cada triênio um relatório diagnóstico detalhando e correlacionando os aquíferos com as Unidades Hidrográficas de Gerenciamento de Recursos Hídricos (UGRHI). O relatório mais recente apresenta dados das campanhas de 2013 a 2015, e mostra análises gerais dos aquíferos do estado (Figura 2), observa-se que o Sistema Aquífero 
Bauru e o Serra Geral se destacam com maior amplitude e maiores concentrações de nitrato, conforme mencionado anteriormente.

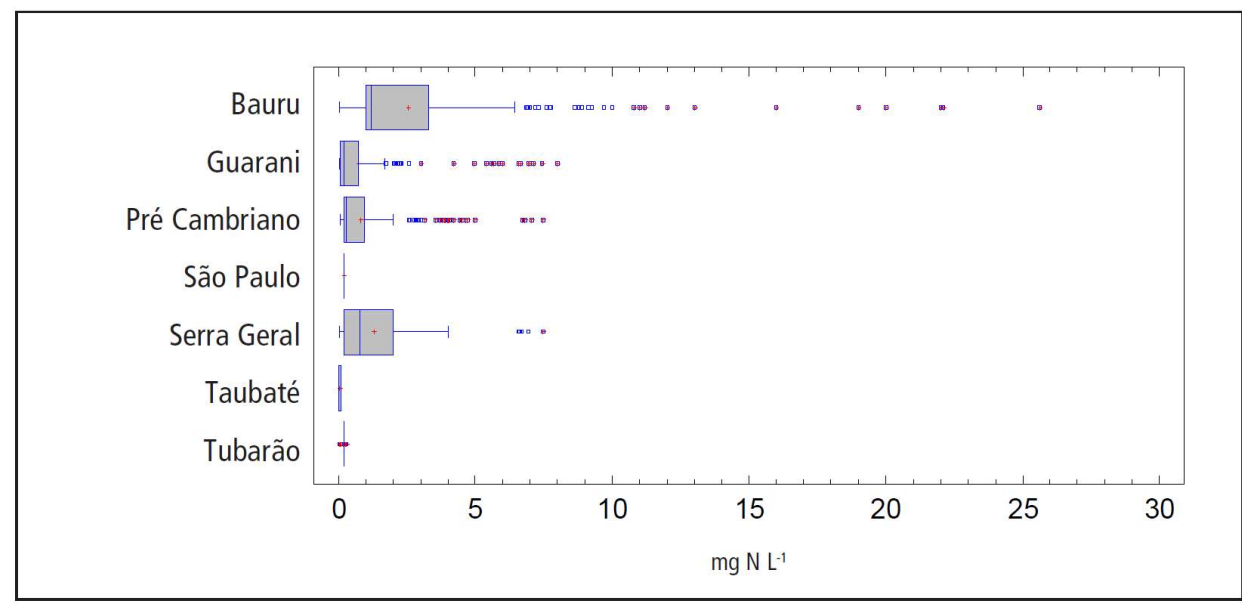

Figura 2 - Box-and-whisker - Nitrogênio nitrato 2013 a 2015 (CETESB, 2016).

$\mathrm{Na}$ última campanha, as concentrações de $\mathrm{N}^{-\mathrm{NO}_{3}}{ }^{-}$acima do padrão de potabilidade foram registradas somente no Sistema Aquífero Bauru (Tabela 2), enquanto que a presença de nitrato acima do valor de prevenção de $5 \mathrm{mg} \mathrm{N} / \mathrm{L}$ foi detectada nos aquíferos Bauru, Guarani, Serra Geral e Pré-Cambriano.

A concentração máxima registrada de $25,6{\mathrm{mg} \mathrm{N}-\mathrm{NO}_{3}}^{-} / \mathrm{L}$ foi registrada em Dirces Reis, no Triênio anterior a maior concentração havia sido de $19 \mathrm{mg} \mathrm{N}-\mathrm{NO}_{3}{ }^{-} / \mathrm{L}$ em Andradina, nota-se que este município apresenta valores ainda maiores neste triênio (Tabela 2). E apesar destes valores, a concentração média acima do padrão de potabilidade foi de 12,4 mg N-NO${ }^{-} / \mathrm{L}$ para 2010-2012 e 14,26 mg N- N-NO ${ }_{3}^{-} / \mathrm{L}$ para 2013-2015. 
Tabela 2 - Pontos de monitoramento com $\mathrm{N}-\mathrm{NO}_{3}{ }^{-}$acima dos padrões de potabilidade em campanhas realizadas de 2013 a 2015 (CETESB, 2016)

\begin{tabular}{|l|l|l|l|l|l|l|l|}
\hline $\begin{array}{l}\text { Sistema } \\
\text { Aquífero }\end{array}$ & $\begin{array}{l}\text { Número } \\
\text { Amostra }\end{array}$ & $\begin{array}{l}\text { Código } \\
\text { CETESB }\end{array}$ & Município & UGRHI & Ano & Campanha & $\begin{array}{l}\text { Nitrogênio } \\
\text { Nitrato } \\
\text { mg/L }\end{array}$ \\
\hline Bauru & 1303393 & BA0090P & Parapua & 20 & 2013 & 1 & 10 \\
\hline Bauru & 1311484 & BA0127P & São José do rio preto & 15 & 2013 & 1 & 10 \\
\hline Bauru & 1303368 & BA0146P & Tupa & 20 & 2013 & 1 & 10 \\
\hline Bauru & 1303360 & BA0232P & Bauru & 13 & 2013 & 1 & 10 \\
\hline Bauru & 1315830 & BA0232P & Bauru & 13 & 2013 & 2 & 10,8 \\
\hline Bauru & 1505394 & BA0028P & Clementina & 20 & 2015 & 2 & 11 \\
\hline Bauru & 1303429 & BA0040P & Florida paulista & 21 & 2013 & 1 & 11 \\
\hline Bauru & 1303433 & BA0052P & Inubia paulista & 21 & 2013 & 1 & 11 \\
\hline Bauru & 1315927 & BA0040P & Florida paulista & 21 & 2013 & 2 & 11,2 \\
\hline Bauru & 1505396 & BA0090P & Parapua & 20 & 2015 & 2 & 12 \\
\hline Bauru & 1505351 & BA0232P & Bauru & 13 & 2015 & 2 & 12 \\
\hline Bauru & 1505580 & BA0293P & Guzolandia & 18 & 2015 & 2 & 13 \\
\hline Bauru & 1303466 & BA0006P & Andradina & 19 & 2013 & 1 & 16 \\
\hline Bauru & 1504730 & BA0006P & Andradina & 19 & 2015 & 1 & 19 \\
\hline Bauru & 1315996 & BA0006P & Andradina & 19 & 2013 & 2 & 20 \\
\hline Bauru & 1505576 & BA0006P & Andradina & 19 & 2015 & 2 & 22 \\
\hline Bauru & 1518721 & BA0026P & Dirce Reis & 18 & 2015 & 2 & 22,1 \\
\hline Bauru & 1506229 & BA0026P & Dirce Reis & 18 & 2015 & 1 & 25,6 \\
\hline
\end{tabular}

Embora o monitoramento nesse triênio tenha apresentado uma tendência de redução da presença de nitrato nas amostras em geral, nota-se que os pontos com altas concentrações ainda continuam apresentando aumento, além disso a CETESB ainda o aponta o Sistema Aquífero Bauru como sendo o sistema com maior concentração de nitrato, ao mesmo tempo que se verificam novos registros de contaminação das águas de poços que se localizam nas áreas urbanizadas.

\subsection{Estequiometria das reações do nitrato}

\subsubsection{Variação da alcalinidade no processo de desnitrificação}

O efeito da desnitrificação sobre a alcalinidade pode ser deduzido por relações estequiométricas, empregando-se a relação da equação 5 obtida por Van Haandel et al. (2009). Observa-se que há envolvimento de íons de hidrogênio, havendo o consumo de $1 \mathrm{~mol} \mathrm{de} \mathrm{H}^{+}$por mol de nitrato reduzido. Sabendo-se que a produção de $1 \mathrm{~mol}$ de $\mathrm{H}^{+}$(acidez mineral) equivale ao consumo de $1 \mathrm{~mol}$ de alcalinidade (ou $50 \mathrm{~g} \mathrm{CaCO}_{3}$ ), tem-se a produção de $50 \mathrm{~g} \mathrm{CaCO}_{3}$ por mol N. As variações da alcalinidade podem ser expressas como:

$$
\frac{\Delta a l c}{\Delta N} d=\frac{50}{14}=3,57 m g \mathrm{CaCO}_{3} \cdot \mathrm{mgN}^{-1}
$$


Onde:

$\frac{\Delta a l c}{\Delta N} d$ : variação da alcalinidade por mg $\mathrm{N}$ na desnitrificação.

\subsubsection{Transferência de elétrons no processo de desnitrificação}

A transferência de elétrons através da nitrificação do nitrogênio amoniacal a nitrato, libera 8 elétrons, os quais somente 5 são recuperados quando o nitrato é reduzido para nitrogênio molecular. E a nitrificação do nitrogênio amoniacal a nitrito libera 6 elétrons dos quais 3 são recuperados redução a nitrogênio molecular (VAN HAANDEL; MARAIS,1999).
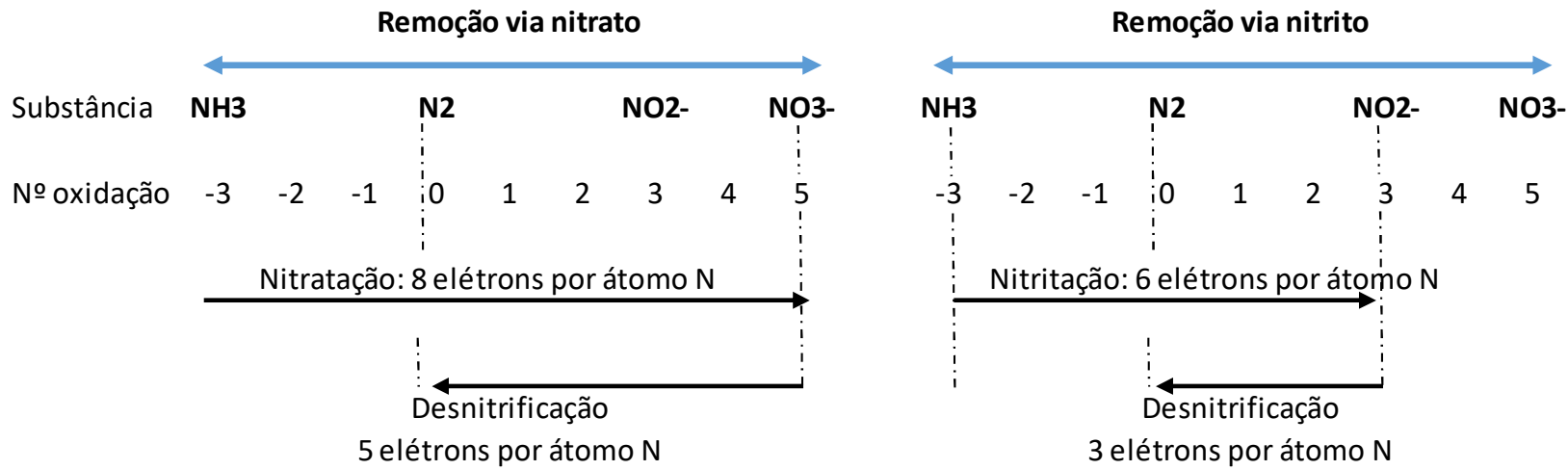

Figura 3 - Variação do número da transferência de elétrons de nitrogênio nos processos de nitrificação e desnitrificação (Adaptado, VAN HAANDEL; MARAIS, 1999).

\subsection{Tratamentos existentes para remoção de nitrato}

Historicamente as fontes de recursos hídricos utilizadas para abastecimento público são aquelas que apresentam o melhor custo-benefício, viabilidade técnica e econômica.

Como já comentado, o nitrato é estável e bastante solúvel em água, e seu excedente não absorvido pelas plantas acaba por mover-se conjuntamente com a água subterrânea devido ao seu baixo potencial de adsorção no solo (MEURER, 2004). Tais fatores, aliados à difícil remoção desse ânion pelos meios convencionais, justificam as diversas pesquisas na busca por alternativas de tratamento do nitrato.

\subsubsection{Processos físico-químicos}

As primeiras alternativas de tratamento de nitrato iniciaram-se no setor industrial, sobretudo na forma de processos físico-químicos. Atualmente, diversas tecnologias são aplicadas com esse fim, e que são brevemente apresentadas a seguir. 


\section{Membranas filtrantes}

Uma membrana pode ser considerada um filtro que elimina compostos maiores do que seu peso molecular de corte, em outras palavras, as membranas filtrantes são barreiras físicas semipermeáveis através das quais os sólidos são retidos de forma seletiva devido ao seu tamanho quando uma pressão é aplicada. Segundo Ribeiro e Luca (1998), os tipos de filtração podem ser divididos em quatro categorias: microfiltração, ultrafiltração, nanofiltração e osmose reversa (Figura 4).

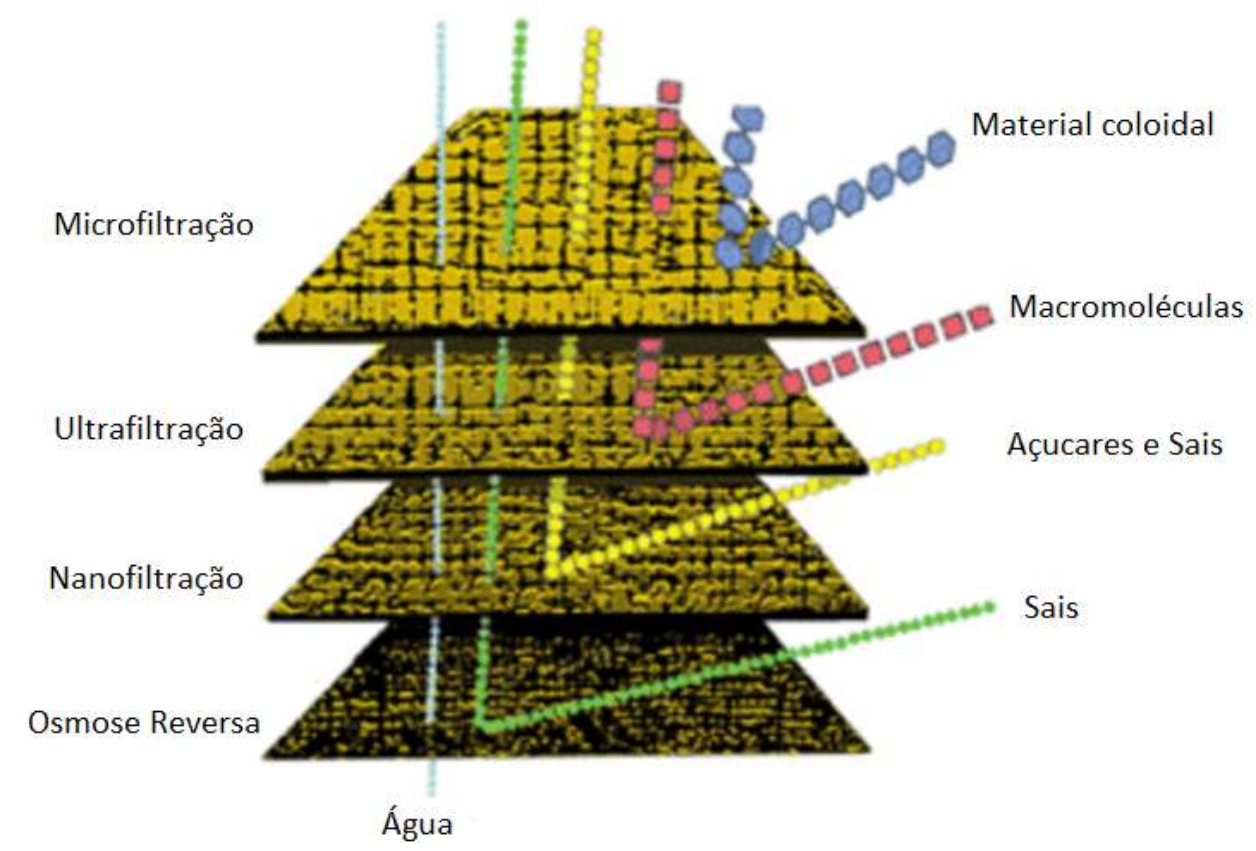

Figura 4 - Tipos de membranas e materiais retidos (Adaptado, PEARSON, 2015).

Os dois primeiros processos requerem uma pressão de serviço menor que $500 \mathrm{kPa}$. São membranas porosas e separam as partículas por tamanho, principalmente indicados para separação sólido/líquido e eliminação de partículas. As membranas de microfiltração podem reter partículas na faixa de 0,05 a $10 \mu \mathrm{m}$, e as de ultrafiltração detêm partículas minerais, orgânicas e biológicas equivalentes a algas, bactérias e vírus.

As membranas de nanofiltração e a osmose reversa, por outro lado, requerem pressões de serviço a partir de $800 \mathrm{kPa}$. São membranas densas (não porosas) e seu mecanismo de separação baseia-se na diferença dos coeficientes de solubilidade e difusão entre o solvente e o soluto, podendo deter partículas do tamanho de íons (RIBEIRO; LUCA, 1998; AQUINO, 2011). As principais aplicações da osmose reversa são nos processos de dessalinização de águas salobras na indústria e nos processos de hemodiálise na área da saúde.

Apesar das membranas filtrantes reterem partículas de diferentes tamanhos, seu uso pode ser combinado com adsorção sobre carvão ativado em pó ou polímeros, permitindo que membranas com menor pressão de serviço possam também ser utilizadas para eliminar partículas menores (SMITH, 1996) sem aplicação de maiores pressões de serviço. 
Para remoção do nitrato por processos de tratamento envolvendo membranas, a nanofiltração acrescida de polímero e a osmose reversa são os métodos mais aconselháveis visto a capacidade granulométrica destas (RIBEIRO; LUCA, 1998). O pré-tratamento, através da filtração de partículas maiores, auxilia para maior prazo entre a manutenção e limpeza dos filtros prolongando a vida útil do processo.

\section{$\underline{\text { Resina ou membrana de troca iônica }}$}

O tratamento a partir de membranas de troca iônica (Figura 5) envolve a substituição de íons presentes na água por uma quantidade equivalente de outras espécies iônicas. Nesse processo, os íons de interesse são retidos em uma fase sólida imiscível, podendo ser uma resina ou membrana (MIERZWA, 2011).

Em função do tipo de íon que se deseja reter, as resinas podem ser catiônicas, com sítios ativos fixos de carga negativa para retenção de cátions ou aniônicas, com sítios ativos fixos de carga positiva para retenção de ânions.

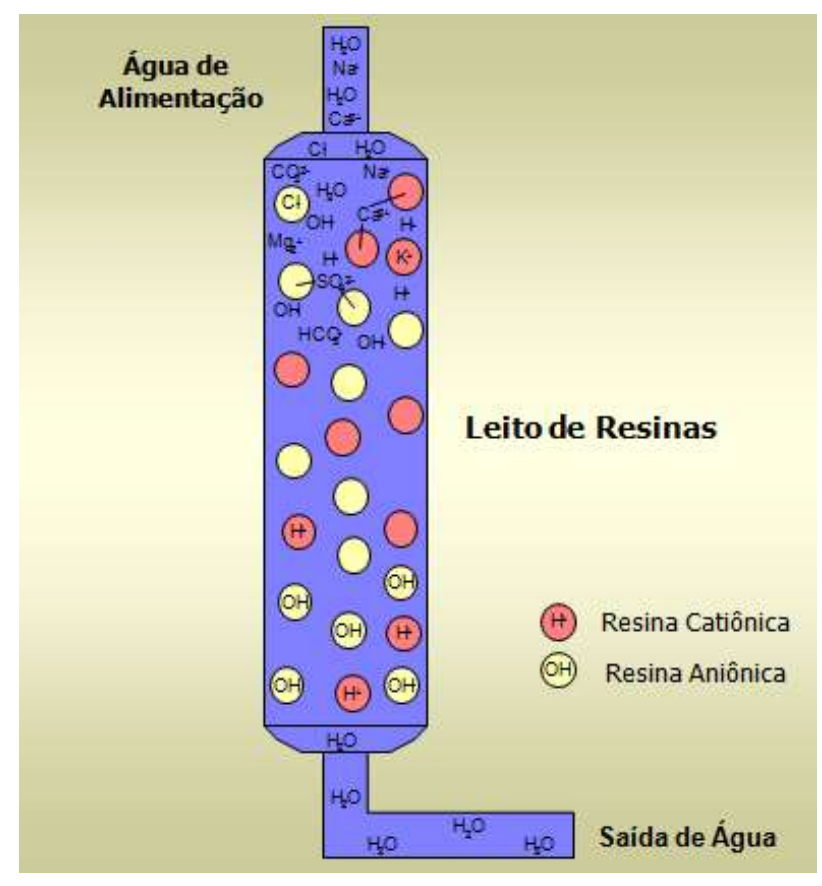

Figura 5 - Processo de troca iônica (MIERZWA, 2011).

Mierzwa (2011) aponta que devido às resinas estarem em fase sólida insolúvel, estas apresentam capacidade limitada de sítios ativos para realização da troca iônica. No entanto as resinas podem ter a sua capacidade recuperada, através de uma nova reação de equilíbrio químico.

Para remoção de nitrato, a resina ou membrana é geralmente composta de base forte em que os íons nitrato são trocados por íons bicarbonato ou cloreto até que a capacidade de troca da resina seja esgotada (DARBI et al., 2002). 
No artigo publicado por Clifford e Liu em 1993, intitulado Troca iônica para remoção de Nitrato, o tratamento por membranas de troca iônica já era considerado um dos processos mais comuns nos Estados Unidos, tendo na época da publicação do artigo, 15 plantas em operação. O processo também é recomendado na publicação da OMS (2011) juntamente com o tratamento por desnitrificação biológica como alternativa de remoção de nitrato.

Apesar disso, Mohseni-Bandpi et al. (2013) citam como principal desvantagem do processo de troca iônica a produção de subprodutos como o lodo, rico em nitrato, cloreto e sulfato, sendo este difícil de descartar.

\section{Eletrodiálise}

O processo de eletrodiálise (Figura 6) atua de maneira combinada com a membrana de troca iônica, em que o transporte seletivo de íons ocorre através desta, sob a influência de um campo elétrico (BANASIAK et al., 2007; MIERZWA, 2011).

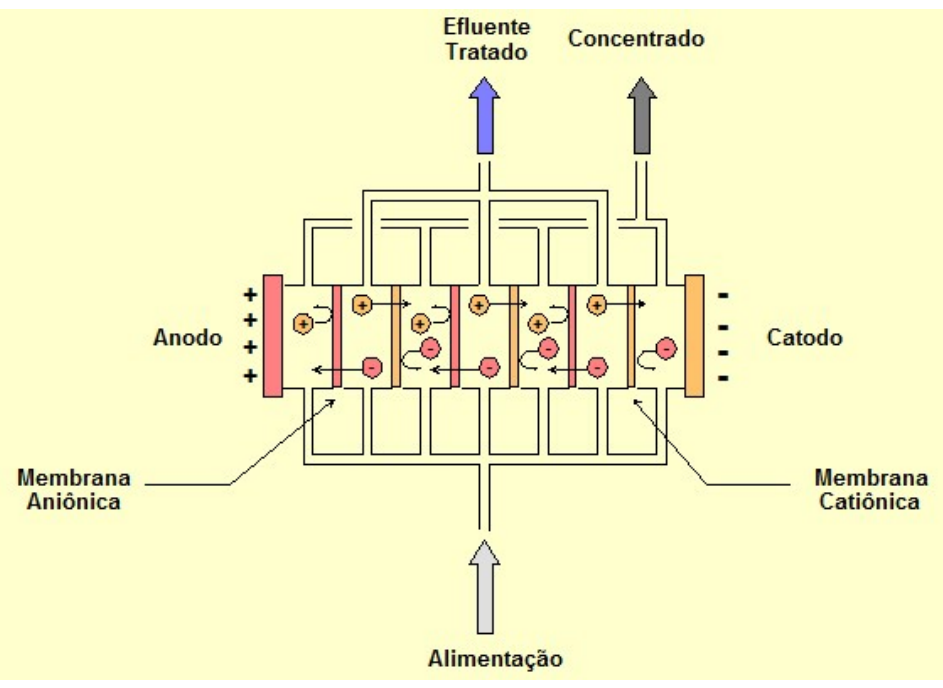

Figura 6 - Processo de eletrodiálise (MIERZWA, 2011).

Segundo Kapoor e Viraraghavan (1997), os íons são transferidos através da membrana de troca iônica do ambiente menos concentrado para o mais concentrado devido à passagem direta da corrente elétrica. Além disso, o processo requer fornecimento de água pressurizada (345-518 $\mathrm{kPa}$ ) e um pré-tratamento da água semelhante ao utilizado para osmose reversa.

Outra técnica utilizada também é a eletrodiálise reversa, na qual a polaridade dos eletrodos é invertida objetivando modificar a direção do movimento de íons. Silva (2013) aponta como principal vantagem desse processo a capacidade de autolimpeza das membranas durante a operação de longo prazo, garantindo uma taxa de fluxo.

Segundo Rautenbach et al. (1987), a eficiência de remoção de nitrato de processos de eletrodiálise e osmose reversa são semelhantes. O processo de eletrodiálise é limitado ao tratamento de águas com baixos níveis de dureza, e tem taxas de recuperação de água mais elevadas do que processos de osmose reversa. Em relação ao custo, segundo Kapoor e 
Viraraghavan (1997) ainda é considerado um processo caro, que exige acompanhamento de perto.

As técnicas de remoção de nitrato por processos físico-químicos são vastamente aplicadas no setor industrial, porém no setor de abastecimento público elas perdem força devido ao seu elevado custo de implantação, operação e manutenção. Ademais, tais técnicas ainda apresentam baixa seletividade à remoção de nitrato (MOHSENI-BANDPI et al., 2013).

\subsubsection{Processos biológicos}

Processos biológicos vem sendo cada vez mais explorados como sistemas de tratamento alternativo para remoção do nitrato. Eles têm como vantagem a geração de nitrogênio gasoso como principal produto final, forma inofensiva para o meio ambiente (MOHSENI-BANDPI et al., 2013).

A remoção de nitrato através dos processos biológicos ocorre por meio da potencialização do processo de nitrificação e desnitrificação, tendo como principal desafio o subsídio de condições ótimas para as bactérias se desenvolverem. O processo de desnitrificação seja ele por intermédio de bactérias autotróficas ou heterotróficas apresenta vantagens e desvantagens em sua aplicação.

Segundo pesquisas (KAPOOR; VIRARAGHAVAN, 1997; VAN LOOSDRECHT; JETTEN, 1998; ZHAO et al., 2011; SAEEDI et al., 2012; MOHSENI-BANDPI et al., 2013), sistemas que empregam bactérias heterotróficas representam maior eficiência de remoção de nitrato e simplicidade no controle do processo, no entanto há necessidade de um pós-tratamento para garantir a remoção das concentrações de matéria orgânica gerada pelo crescimento das bactérias e subprodutos advindos do excesso de carbono orgânico (HAMLIN et al., 2008). Em contrapartida, sistemas operados por bactérias autotróficas geram menos lodo e não necessitam de pós-tratamento, porém sua eficiência de remoção é baixa e seu processo é de complexa operação (Mohseni-Bandpi et al., 2013).

Processos que utilizam desnitrificação podem ter diversos arranjos, de acordo com as características intrínsecas do recurso hídrico, bem como clima, disponibilidade e viabilidade de utilizar determinadas fontes de carbono, características da água a ser tratada, e outros fatores como a composição do aquífero a ser implantado o tratamento.

Segundo Flere e Zhang (1999), sistemas de desnitrificação por bactérias autotróficas utilizando enxofre e calcário, conhecidos como SLAD (Sulfur-Limestone Autotrophic Denitrifying) vêm sendo estudados por pesquisadores na Europa, verificando-se 95\% de eficiência no tratamento. Luna-Velasco et al. (2010) estudaram essa técnica para remoção de $\mathrm{NO}_{3}{ }^{-}$e U ${ }^{6+}$ de águas subterrâneas, utilizando o processo de desnitrificação combinado a um biorreator revestido com ferro elementar $\left(\mathrm{Fe}^{0}\right)$, e obtiveram $99,8 \%$ de eficiência de remoção de nitrato e urânio. 
Processos que envolvem o uso de biofilmes são de grande interesse para tratamento das águas, os sistemas são em geral, compostos por comunidades de bactérias envoltas por substâncias, principalmente açúcares, produzidas pelas próprias bactérias, e suas estruturas podem atingir dimensões macroscópicas para formação de filtros biológicos de remoção de nitrato (EGLI et al., 2003). Técnicas utilizando biofilmes para remoção de nitrato por bactérias heterotróficas também foram estudadas por Fuchs et al. (1997), em seu trabalho é apresentado um arranjo de tratamento que não necessita de pós-tratamento; no entanto é necessário aprimoramento do material utilizado como matéria-prima para fabricação da membrana devido a seus altos custos.

Schipper et al. (2010) analisaram a remoção de nitrato ainda por bactérias heterotróficas nas águas subterrâneas in situ, envolvendo diferentes arranjos de biorreatores desnitrificantes, dentre eles: paredes de desnitrificação, interceptando águas subterrâneas rasas; leitos desnitrificantes, interceptando descargas de poluente concentradas; e camadas desnitrificantes, interceptando lixiviado no solo. Além de diferentes arranjos pode-se variar também o material reativo, Cesarino (2002) analisou o uso de papel jornal, serragem, palha de aço e enxofre em experimentos em escala laboratorial, sendo a serragem o material com melhor desempenho no processo de desnitrificação (97\%).

Visando aproveitar as vantagens das vias de desnitrificação de forma integrada, pesquisas estão avançando na proposição de processos conjuntos. ZHAO et al. (2011) propõem o uso de um sistema conjunto conhecido como IBER (Intensified Biofilm-Electrode Reactor) que combina bactérias heterotróficas e autotróficas com a utilização de hidrogênio como doador de elétrons. Varetas de carbono são usadas como ânodo e o arame de aço inoxidável incorporado em fibras atua como cátodo para fornecer $\mathrm{H}_{2}$ para as bactérias autotróficas. As bactérias em seguida utilizam $\mathrm{O} \mathrm{CO}_{2}$, proveniente do processo de desnitrificação das bactérias heterotróficas, como parte da fonte de carbono inorgânico necessária, tornando o processo cíclico.

Saeedi et al. (2012) analisaram a remoção de nitrato e matéria orgânica de maneira simultânea através de um processo utilizando bactérias heterotróficas e autotróficas por meio de um biorreator de carvão ativado. A tecnologia intitulada de HHABB (Hybrid Heterotrophic/Autotrophic/Bac Bioreactor) consiste no uso de três compartimentos: etanol na parte heterotrófica, enxofre na parte autotrófica, e carvão ativado na parte biológico. Segundo os autores, a eficiência do processo de remoção de nitrato foi de 96 a 97,7\% e o efluente carbono orgânico dissolvido e formação de concentrações de trihalometanos potenciais foram relativamente baixos.

Além dos arranjos de tratamentos envolvendo combinações entre processos biológicos de óxido-redução, há pesquisas que recomendam alternar o uso de processos físico-químicos aos processos biológicos visando explorar as vantagens de cada técnica. 
Hoek e Klapwijk (1987) propuseram o uso da técnica de troca iônica seguida de desnitrificação biológica. Esta combinação objetivou o aproveitamento do processo de regeneração das membranas de troca iônica combinada com um reator de desnitrificação, permitindo a conexão de subprodutos para seu melhor aproveitamento. O processo (Figura 7) consiste no uso de uma substância regeneradora de membrana $\left(\mathrm{NaHCO}_{3}\right.$ ou $\left.\mathrm{NaCl}\right)$ para a troca de íons de nitrato com íons bicarbonato, sendo que o nitrato segue para desnitrificação através de um reator fechando o ciclo. Em contraste com os procedimentos tradicionais, não há contato direto entre as águas subterrâneas e as bactérias desnitrificantes, o que minimiza os riscos de contaminação bacteriológica da água tratada e intenso processo de pós-tratamento (HOEK; KLAPWIJK, 1987). Os resultados da pesquisa mostram que, em planta piloto, o processo é muito atraente quando comparado com as técnicas tratadas separadamente.

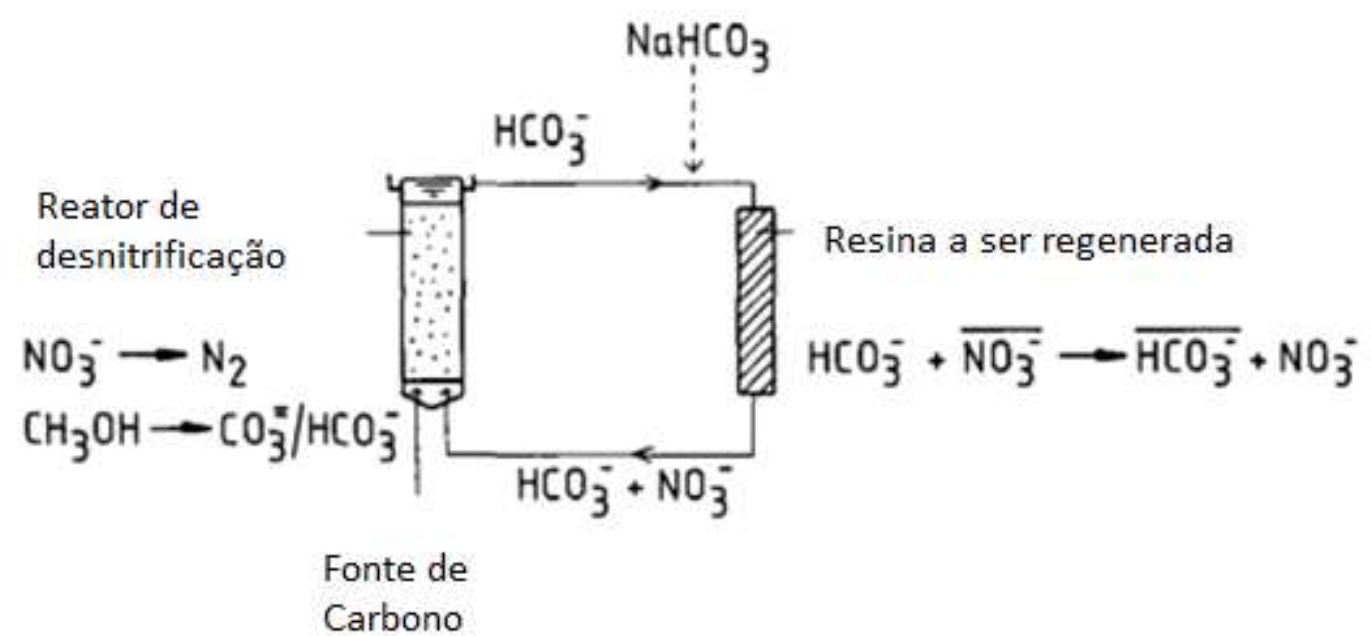

Figura 7 - Regeneração da membrana de troca iônica através de bicarbonato seguindo para reator de desnitrificação (HOEK; KLAPWIJK, 1987).

Pintar et al. (2001) também analisaram um sistema que não promove o contato direto entre a água tratada e os microrganismos. O processo consiste em um circuito fechado (batelada) contendo um reator catalítico de fluxo único com leito fixo combinado com membranas de troca iônica. Os resultados mostraram-se satisfatórios tendo em vista a concentração inicial de nitrato de $100 \mathrm{mg} \mathrm{NO}_{3}^{-} / \mathrm{L}$ reduzindo a $0 \mathrm{mg} \mathrm{NO}_{3}^{-} / \mathrm{L}$ em 200 minutos no ciclo, podendo inclusive remover sulfatos conjuntamente no processo.

\subsubsection{Processos bioeletroquímicos}

Além dos diversos arranjos e técnicas de tratamento combinadas, processos bioeletroquímicos vêm ganhando destaque devido ao seu potencial no uso para geração de 
energia (WANG; REN, 2013), e recentemente pela sua aplicação para tratamento de águas de abastecimento e residuárias.

\subsubsection{1 $\quad$ Considerações Gerais}

O conceito de geração de energia através de microrganismos é conhecido desde 1910, quando Potter (1911) realizou experimentos que demonstravam a produção de energia em culturas como Escherichia coli e Saccharomyces. No entanto, os processos bioeletroquímicos tiveram maior difusão e aprofundamento em pesquisas na última década (WANG; REN, 2013), seguindo a tendência de interdisciplinaridade entre diversos campos como microbiologia, eletroquímica, ciência dos materiais, engenharia e muitas áreas relacionadas (LOGAN, 2009; WANG; REN, 2013; KELLY; HE, 2014).

Basicamente, o sistema utiliza processos biológicos e processos físico-químicos (eletrolise) de maneira combinada. Sua estrutura consiste em uma câmara anódica onde ocorre a oxidação da matéria orgânica e uma câmara catódica onde ocorre o processo de redução (Figura 8). Entre as câmaras é utilizada uma membrana de troca iônica de forma a permitir somente a passagem de prótons da câmara anódica para a catódica, além de impedir a difusão de oxigênio para a câmara catódica.

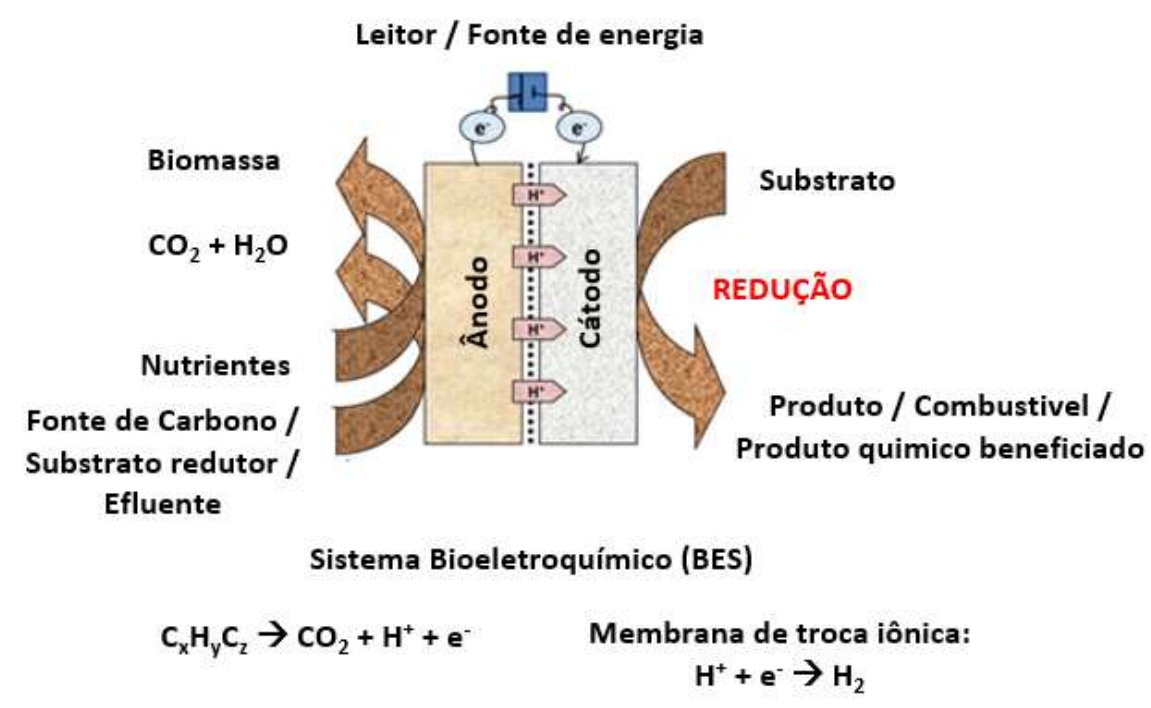

Figura 8 - Sistema bioeletroquímico (Adaptado, BOROLE et al., 2011).

A Tabela 3 apresenta os componentes básicos utilizados em estudos existentes e seus materiais. 
Tabela 3 - Componentes básicos para um sistema bioeletroquímico

\begin{tabular}{|c|c|c|c|}
\hline Item & Material & Referências & Necessidade \\
\hline \multirow{7}{*}{ Ânodo } & Grafite & $\begin{array}{l}\text { Rabaey e Verstraete, 2005; Logan et al., 2006; } \\
\text { Bullen et al., 2006; Du et al., 2007; Virdis et al., } \\
\text { 2010; Zhang e Agelidaki, } 2013\end{array}$ & \multirow{7}{*}{ Necessário } \\
\hline & Feltro de grafite & Logan et al., 2006; Lovley, 2006; Du et al., 2007 & \\
\hline & Papel carbono & $\begin{array}{l}\text { Logan et al., 2006; Du et al., 2007; Pous et al., } \\
2013\end{array}$ & \\
\hline & Tecido de carbono & $\begin{array}{l}\text { Logan et al., 2006; Du et al., 2007; Tong e He, } \\
2013\end{array}$ & \\
\hline & Platina $(\mathrm{Pt})$ & \multirow{2}{*}{ Du et al., 2007} & \\
\hline & Platina preta & & \\
\hline & $\begin{array}{l}\text { RVC (Carbono Vítreo } \\
\text { Reticulado) }\end{array}$ & Logan et al., 2006; Du et al., 2007 & \\
\hline \multirow{7}{*}{ Cátodo } & Grafite & $\begin{array}{l}\text { Logan et al., 2006; Bullen et al., 2006; Du et al., } \\
\text { 2007; Virdis et al., 2010; Zhang e Agelidaki, } 2013\end{array}$ & \multirow{7}{*}{ Necessário } \\
\hline & Feltro de grafite & $\begin{array}{l}\text { Rabaey e Verstraete, 2005; Logan et al., 2006; } \\
\text { Lovley, 2006; Du et al., } 2007\end{array}$ & \\
\hline & Papel carbono & $\begin{array}{l}\text { Logan et al., 2006; Du et al., 2007; Pous et al., } \\
2013\end{array}$ & \\
\hline & Tecido de carbono & $\begin{array}{l}\text { Logan et al., 2006; Du et al., 2007; Tong e He, } \\
2013\end{array}$ & \\
\hline & Platina $(\mathrm{Pt})$ & Du et al., 2007 & \\
\hline & Platina preta & Du et al., 2007 & \\
\hline & $\begin{array}{l}\text { RVC (Carbono Vítreo } \\
\text { Reticulado) }\end{array}$ & Logan et al., 2006; Du et al., 2007 & \\
\hline \multirow{4}{*}{$\begin{array}{l}\text { Câmera } \\
\text { anódica }\end{array}$} & Vidro & \multirow{4}{*}{ Du et al., 2007} & \multirow{4}{*}{ Necessário } \\
\hline & Policarbonato & & \\
\hline & Acrílico & & \\
\hline & PVC & & \\
\hline \multirow{4}{*}{$\begin{array}{l}\text { Câmera } \\
\text { catódica }\end{array}$} & Vidro & $\begin{array}{l}\text { Rabaey e Verstraete, 2005; Lovley, 2006; Du et } \\
\text { al., } 2007\end{array}$ & \multirow{4}{*}{ Opcional } \\
\hline & Policarbonato & \multirow{3}{*}{ Du et al., 2007} & \\
\hline & Acrílico & & \\
\hline & PVC & & \\
\hline \multirow{5}{*}{$\begin{array}{l}\text { Membrana } \\
\text { de troca } \\
\text { iônica }\end{array}$} & $\begin{array}{l}\text { Membrana: Nafion, } \\
\text { Ultrex }\end{array}$ & $\begin{array}{l}\text { Rabaey e Verstraete, 2005; Du et al., 2007; Virdis } \\
\text { et al., 2010; Zhang e Agelidaki, 2013; Pous et al., } \\
\text { 2013; Tong e He, 2013; Logan et al., 2006; Du et } \\
\text { al., } 2007\end{array}$ & \multirow{5}{*}{ Necessário } \\
\hline & $\begin{array}{l}\text { Polietileno (estireno- } \\
\text { co-divinilbenzeno) }\end{array}$ & \multirow{4}{*}{ Du et al., 2007} & \\
\hline & Ponte salina & & \\
\hline & Septo de porcelana & & \\
\hline & Unicamente eletrólito & & \\
\hline \multirow[t]{2}{*}{$\begin{array}{l}\text { Meio } \\
\text { suporte para } \\
\text { crescimento } \\
\text { bacteriano }\end{array}$} & Grafite granular & $\begin{array}{l}\text { Rabaey e Verstraete, 2005; Du et al., 2007; Virdis } \\
\text { et al., 2010; Zhang e Agelidaki, 2013; Pous et al., } \\
\text { 2013; Tong e He, 2013; Logan et al., 2006; Du et } \\
\text { al., 2007 }\end{array}$ & \multirow[t]{2}{*}{ Opcional } \\
\hline & Contas de vidro & Zhang e Agelidaki, 2013 & \\
\hline \multirow{5}{*}{ Catalizador } & Platina $(\mathrm{Pt})$ & \multirow{4}{*}{ Logan et al., 2006; Du et al., 2007} & \multirow{5}{*}{ Opcional } \\
\hline & Platina preta & & \\
\hline & $\begin{array}{l}\text { Óxido de manganês } \\
\text { IV (MnO2) }\end{array}$ & & \\
\hline & Ferro (III) (Fe3+) & & \\
\hline & Polianilina & Du et al., 2007 & \\
\hline
\end{tabular}


As reações típicas que ocorrem em cada câmara são apresentadas a seguir utilizando o acetato como exemplo de substrato (DU et al., 2007):

Reação no ânodo:

$$
\mathrm{CH}_{3} \mathrm{COO}^{-}+2 \mathrm{H}_{2} \mathrm{O} \stackrel{\text { microrganismos }}{\longrightarrow} 2 \mathrm{CO}_{2}+7 \mathrm{H}^{+}+8 e^{-} \quad \text { Equação } 6
$$

Reação no cátodo:

$$
\mathrm{O}_{2}+4 e^{-}+4 \mathrm{H}^{+} \rightarrow 2 \mathrm{H}_{2} \mathrm{O}
$$

Suas aplicações vão desde geração de eletricidade, beneficiamento de produtos químicos, biosensores e tratamento de efluentes. A reação de oxidação microbiana na câmara do ânodo é o princípio comum para quase todos os reatores que utilizam esse sistema.

O processo bioeletroquímico tem como principal diferencial sua capacidade de utilizar microrganismos para oxidar matéria orgânica e liberar elétrons no ânodo, sem a necessidade de realizar o processo de oxidação catalítica através de catalisadores metálicos, como ocorre em processos que utilizam células de combustível convencionais (LOGAN, 2009).

Diversas são as nomenclaturas utilizadas abordando os sistemas bioeletroquímicos: MES (Microbial Electrochemical Systems) para Sistema Microbiano Eletroquímico; BES (Bioelectrochemical System) para Sistemas Bioeletroquímicos (BOROLE et al., 2011); MXC para Célula "X" Microbiana, em que "X" representa simplesmente a função principal e benefício de uma célula específica (WANG; REN, 2013), como, por exemplo, a célula de dessalinização microbiana (MDC - Microbial Desalination Cells), ou célula de combustível microbiana (MFC Microbial Fuel Cells), que possui como principal função a geração de eletricidade (LOGAN et al., 2006). Quando uma fonte de alimentação de energia externa é adicionada a um reator MFC como um catalisador na diferença de potencial dos campos elétricos, o sistema torna-se uma célula de eletrólise microbiana (MEC), na qual a produção do gás de hidrogênio ou de outros compostos pode ser o objetivo do processo.

A Figura 9 ilustra o arranjo dos principais tipos de processos bioletroquímicos atualmente empregados. 


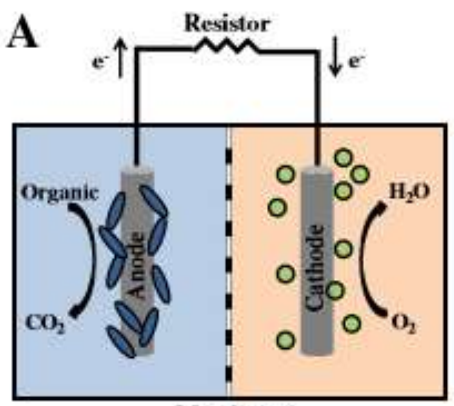

Membrane

(optional)

C

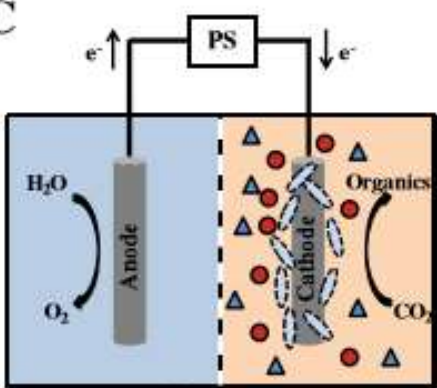

Membrane

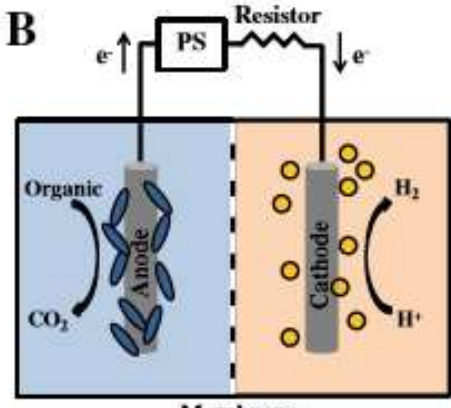

Membrane

(optional)

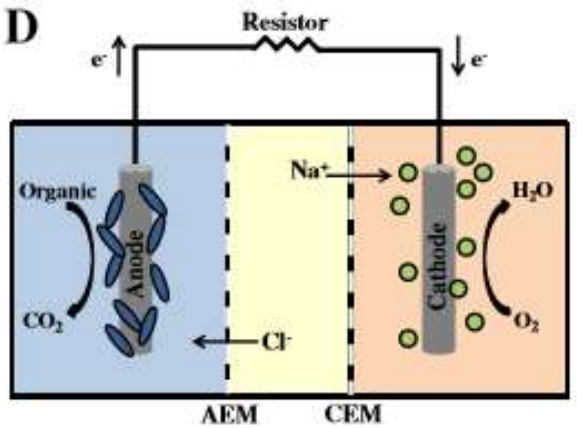

OAnode Bacteria

Sistema A: Geração de energia em uma MFC

Sistema B: Geração de hidrogênio com uso de uma fonte externa de energia em uma MEC

Sistema C: Produção química através de uma MES

Sistema D: Processo de dessalinização através de uma MDC

Figura 9 - Princípios básicos de típicos processos bioeletroquímicos (WANG e REN, 2013).

Além da variação dos tipos de processos, ainda encontra-se em literatura uma variedade de layouts para os sistemas bioeletroquímicos. Logan et al. (2006) apresentam diversos sistemas estudados (Figura 10 e Figura 11). O formato de " $\mathrm{H}$ " é bastante aplicado nas pesquisas existentes. A Figura 10-F apresenta o layout tido como de menor custo. Os autores ainda citam que o principal ponto na configuração do layout de um sistema bioeletroquímico está na escolha da membrana de troca iônica, de forma que permita a passagem de prótons entre as câmaras sem a permitir a passagem do aceptor de elétrons para a câmara catódica (geralmente o oxigênio). Logan et al. (2006) apontam que no formato "H" o comprimento e o próprio tubo de ligação entre as câmaras não são necessários, conforme é apresentado nas Figura 10-B, Figura 10-C, Figura 10-D e Figura 10-E.

O experimento de Rosenbaum et al. (2005) (Figura 10-D) com células fotobioeletroquímicas apresenta a geração de eletricidade com base na oxidação in situ de hidrogênio fotobiológico, através das atividades metabólicas da Rhodobacter sphaeroides. Sua construção baseou-se em conceitos do processo bioeletroquímico. 


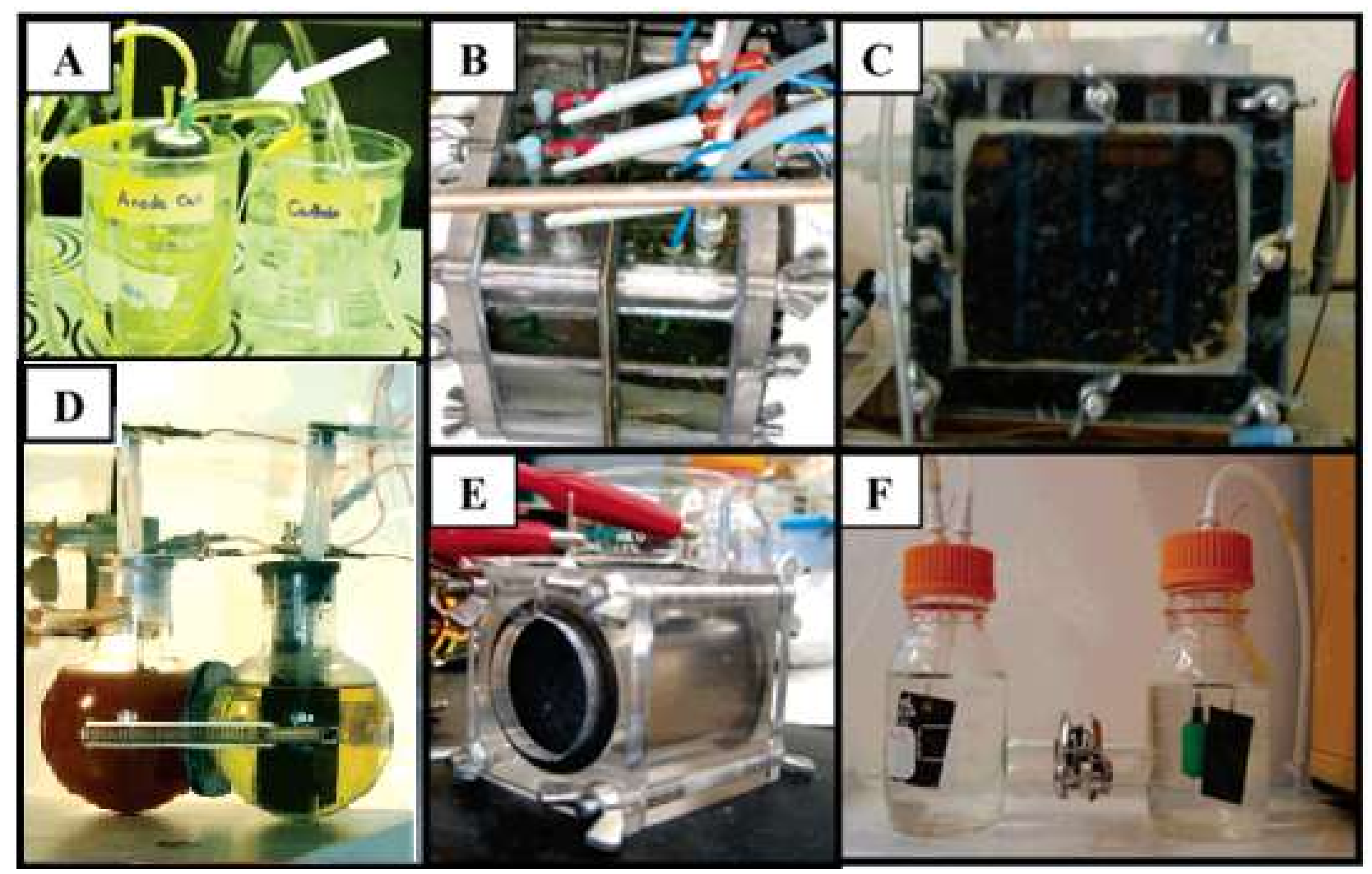

(A) Sistema contendo ponte de salina facilmente construído (mostrada pela seta) (MIN et al., 2005);

(B) Conjunto de MFCs em sistema de batelada em que as câmaras estão separadas pela membrana (sem um tubo) e mantidos juntos por meio de parafusos (RABAEY et al., 2005');

(C) Sistema similar ao B, mas com um ânodo em fluxo contínuo (matriz de grafite granular) (RABAEY et al., 2005²);

(D) MFC tipo fotobioeletroquímica (ROSENBAUM et al., 2005);

(E) Câmara única, sistema de ar-cátodo em um simples arranjo "tubo" (LIU e LOGAN, 2004);

(F) Sistema em layout "H" equipado com pulverização de gás (LOGAN et al., 2005).

Figura 10 - Diferentes tipos de ligações da membrana de troca iônica em MFCs (Adaptado, LOGAN et al., 2006).

Além do formato em "H", foram testadas variações nos sistemas bioeletroquímicos de forma a otimizar os objetivos propostos, como o aumento da densidade de energia gerada ou operação do sistema em fluxo contínuo. Na Figura 11-A um reator cilíndrico interior exerce a função de ânodo (que consiste em meios granulares) e o cátodo fica envolto do lado de fora. HE et al. (2005) propõem a concepção do sistema como um reator de fluxo ascendente de biofilme de leito fixo, onde o fluido é escoado continuamente através de ânodos porosos para uma membrana que separa o ânodo do cátodo (Figura 11-B). MIN e LOGAN (2004) projetaram um sistema para se parecer com células de combustível de hidrogênio, onde uma membrana de troca iônica é imprensada entre o ânodo e cátodo (Figura 11-C). Na Figura 11-D o sistema foi concebido em formato cilíndrico com um tubo concêntrico tendo a função de cátodo. Por fim, Aelterman et al. (2006) analisaram um sistema MFC empilhado em uma série de placas planas ou ligados entre si em série (Figura 11-E), de forma a aumentar a tensão do sistema global. 


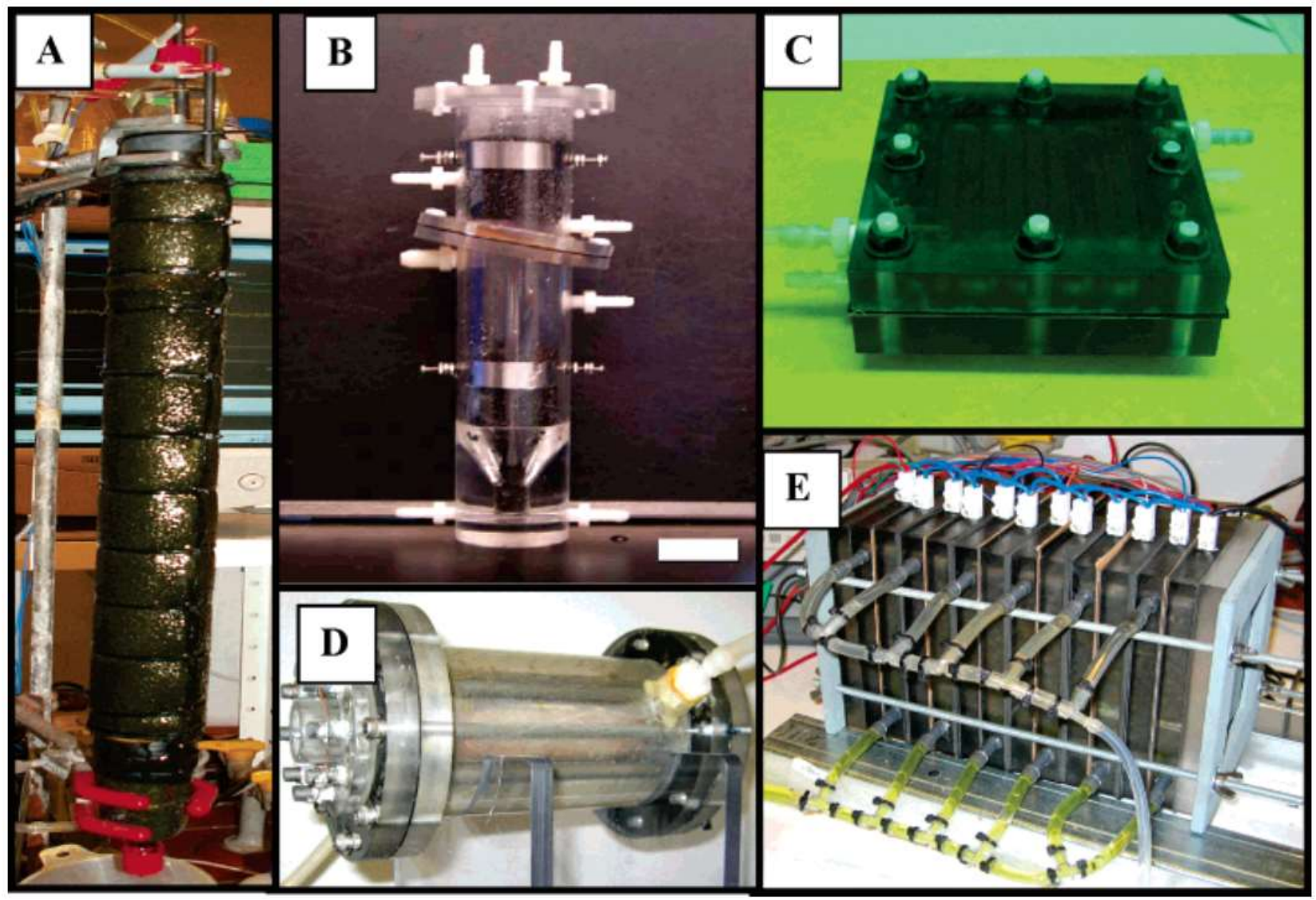

(A) MFC tipo tubular de fluxo ascendente, com ânodo interior de cama de grafite e cátodo exterior (RABAEY et al., 2005³);

(B) MFC tipo tubular de fluxo ascendente, com ânodo abaixo, cátodo acima, e membrana de troca iônica inclinada (HE et al., 2005);

(C) MFC tipo placa plana; o líquido flui em um padrão de serpentina através do eletrodo (MIN; LOGAN, 2004);

(D) MFC tipo tubular de câmara única com um cátodo aerado de forma concêntrica interna rodeado por uma câmara contendo varetas de grafite como ânodo (LIU et al., 2004);

(E) Conjunto de 6 MFCs tipo placa unidos em bloco (AELTERMAN et al., 2006).

Figura 11 - Diferentes tipos de layouts de MFCs (LOGAN et al., 2006).

\subsubsection{Microrganismos com potencial de geração de energia}

Segundo Du et al. (2007), teoricamente a maior parte dos microrganismos podem ser utilizados como biocatalisadores nos processos bioeletroquímicos e citam que as espécies anodófilas são capazes de transferir elétrons diretamente para o ânodo.

Logan (2009) realizou uma pesquisa dos microrganismos (Tabela 4) usualmente utilizados em diferentes processos bioeletroquímicos. Tais microrganismos têm capacidade de converter a energia química armazenada nos substratos orgânicos ou inorgânicos em energia elétrica durante o processo de respiração. 
Tabela 4 - Microrganismos que podem gerar energia (LOGAN, 2009).

\begin{tabular}{|c|c|c|}
\hline Ano & Microrganismos & Descrição \\
\hline 1999 & $\begin{array}{l}\text { Shewanella } \\
\text { putrefaciens IR-1 }\end{array}$ & $\begin{array}{l}\text { Prova direta de geração de corrente elétrica de um MFC por } \\
\text { bactérias dissimilatórias redutoras de metais } \\
\text { (Gammaproteobacteria) }\end{array}$ \\
\hline 2001 & $\begin{array}{l}\text { Clostridium butyricum } \\
\text { EG3 }\end{array}$ & $\begin{array}{l}\text { Primeira bactéria gram-positiva descoberta para produzir corrente } \\
\text { eléctrica em um MFC }\end{array}$ \\
\hline 2002 & $\begin{array}{l}\text { Desulfuromonas } \\
\text { acetoxidans }\end{array}$ & $\begin{array}{l}\text { Identificada uma colônia de sedimentos de MFC capaz de } \\
\text { produzir energia (Deltaproteobacteria) }\end{array}$ \\
\hline 2002 & $\begin{array}{l}\text { Geobacter } \\
\text { metallireducens }\end{array}$ & $\begin{array}{l}\text { Capacidade de gerar eletricidade em um sistema potencialmente } \\
\text { equilibrado (Deltaproteobacteria) }\end{array}$ \\
\hline 2003 & $\begin{array}{l}\text { Geobacter } \\
\text { sulfurreducens }\end{array}$ & Corrente gerada sem eletrodo equilibrado (Deltaproteobacteria) \\
\hline 2003 & $\begin{array}{l}\text { Rhodoferax } \\
\text { ferrireducens }\end{array}$ & Utilização de glicose (Betaproteobacteria) \\
\hline 2003 & $\begin{array}{l}\text { A3 (Aeromonas } \\
\text { hydrophila) }\end{array}$ & Deltaproteobacteria \\
\hline 2004 & $\begin{array}{l}\text { Pseudomonas } \\
\text { aeruginosa }\end{array}$ & $\begin{array}{l}\text { Baixas quantidades de produção de energia através de } \\
\text { mediadores como piocianina (Gammaproteobacteria) }\end{array}$ \\
\hline 2004 & $\begin{array}{l}\text { Desulfobulbus } \\
\text { propionicus }\end{array}$ & Deltaproteobacteria \\
\hline 2005 & $\begin{array}{l}\text { Geopsychrobacter } \\
\text { electrodiphilus }\end{array}$ & Psychrotolerant (Deltaproteobacteria) \\
\hline 2005 & Geothrix fermentans & $\begin{array}{l}\text { Produção de um mediador não identificado (Phylum } \\
\text { Acidobacteria) }\end{array}$ \\
\hline 2006 & $\begin{array}{l}\text { Shewanella oneidensis } \\
\text { DSP10 }\end{array}$ & $\begin{array}{l}\text { Produção de uma elevada quantidade de potência }\left(2 \mathrm{~W} \text { por } \mathrm{m}^{2} \text { ou }\right. \\
500 \mathrm{~W} \text { por } \mathrm{m}^{3} \text { ) por bombeamento de células cultivadas em um } \\
\text { recipiente MFC pequeno }(1,2 \mathrm{~mL}) \text { (Gammaproteobacteria) }\end{array}$ \\
\hline 2006 & S. oneidensis MR-1 & $\begin{array}{l}\text { Várias mutações identificadas que aumentam ou reduzem a } \\
\text { capacidade de geração atual de corrente (Gammaproteobacteria) }\end{array}$ \\
\hline 2006 & Escherichia coli & $\begin{array}{l}\text { Descoberta de produção de corrente após longos períodos de } \\
\text { aclimatação (Gammaproteobacteria) }\end{array}$ \\
\hline 2008 & $\begin{array}{l}\text { Rhodopseudomonas } \\
\text { palustrisDX-1 }\end{array}$ & $\begin{array}{l}\text { Produção de altas densidades de energia de } 2,72 \mathrm{~W} \text { por } \mathrm{m}^{2} \mathrm{em} \\
\text { comparação com a inoculação de esgoto aclimatado } \\
\text { (Alphaproteobacteria) }\end{array}$ \\
\hline 2008 & $\begin{array}{l}\text { Ochrobactrum anthropi } \\
\text { YZ-1 }\end{array}$ & $\begin{array}{l}\text { Um patógeno oportunista, como P. aeruginos } \\
\text { (Alphaproteobacteria) }\end{array}$ \\
\hline 2008 & $\begin{array}{l}\text { Desulfovibrio } \\
\text { desulfuricans }\end{array}$ & $\begin{array}{l}\text { Sulfato é reduzido conforme microrganismo se desenvolve em } \\
\text { associação com lactato; resazurina no meio não foi pensada para } \\
\text { ser um fator na produção de energia (Deltaproteobacteria) }\end{array}$ \\
\hline 2008 & $\begin{array}{l}\text { Acidiphilium sp. } \\
\text { 3.2Sup5 }\end{array}$ & $\begin{array}{l}\text { Corrente em pH baixo e na presença de oxigênio em um sistema } \\
\text { de potencial equilibrado (Alphaproteobacteria) }\end{array}$ \\
\hline 2008 & $\begin{array}{l}\text { Klebsiella pneumoniae } \\
\text { L17* }\end{array}$ & $\begin{array}{l}\text { A primeira vez que essa espécie atual produz corrente sem um } \\
\text { mediador (Gammaproteobacteria) }\end{array}$ \\
\hline 2008 & $\begin{array}{l}\text { Thermincola sp. strain } \\
\text { JR }\end{array}$ & Phylum Firmicutes \\
\hline 2008 & Pichia anomala* & Geração atual formada por levedura (reino Fungi). \\
\hline
\end{tabular}

* Ferricyanide cathode

Dentre as bactérias citadas na Tabela 4, foi reportado por Gregory et al. (2004) que a Geobacter metallireducens possui capacidade de reduzir nitrato. Logan (2009) ainda cita que o 
parâmetro mais importante para melhor desempenho nos sistemas bioeletroquímicos não está somente relacionado à espécie de microrganismos presentes no sistema, mas também aos objetivos da adoção e implantação de um sistema bioeletroquímico, isto é, nem sempre o microrganismo com maior potencial energético constitui o melhor redutor de um determinado componente, como os microrganismos redutores de nitrato por exemplo. O autor cita ainda que uma colônia de variados microrganismos tem vantagens neste aspecto e pode trazer maior benefício para um sistema bioeletroquímico.

\subsubsection{Substrato de alimentação do processo}

Segundo Logan (2009), em teoria, qualquer fonte de matéria orgânica biodegradável pode ser utilizada em um sistema bioeletroquímico para geração de energia, incluindo moléculas simples, tais como carboidratos e proteínas, bem como misturas complexas de matéria orgânica e as águas residuais de processamento de alimentos.

Pant et al. (2009) pesquisaram as fontes de carbono mais utilizadas nos sistemas bioeletroquímicos para geração de energia, e apontaram, como parâmetro comparativo, a unidade de densidade de corrente, a qual é representada como a corrente gerada por unidade de área da superfície do ânodo $\left(\mathrm{mA} / \mathrm{cm}^{2}\right)$ ou corrente gerada por unidade de volume da célula $\left(\mathrm{mA} / \mathrm{m}^{3}\right)$. A unidade de volume é usualmente adotada nos experimentos em que a superfície total do compartimento anódico utilizou de material granular, o qual dificulta a quantificação de superfície por $\mathrm{m}^{2}$. A Tabela 5 apresenta a relação de alguns substratos empregados em sistemas bioeletroquímicos comparados a partir de suas respectivas densidades de corrente. 
Tabela 5 - Relação de alguns substratos utilizados em sistemas bioeletroquímicos e respectivas densidades de corrente (Adaptado, PANT et al., 2009).

\begin{tabular}{|c|c|c|c|c|c|}
\hline Tipo de substrato & Concentrações & \begin{tabular}{|l} 
Fonte \\
inoculadora
\end{tabular} & Tipo de MFC & \begin{tabular}{|l|} 
Densidade \\
de \\
corrente \\
$\left(\mathrm{mA} / \mathrm{cm}^{2}\right)$ \\
\end{tabular} & Referências \\
\hline Acetato & $1 \mathrm{~g} / \mathrm{L}$ & $\begin{array}{l}\text { Bactérias pré- } \\
\text { aclimatadas a } \\
\text { partir de MFC }\end{array}$ & \begin{tabular}{|l|} 
Cuba em forma de \\
uma câmara de \\
MFC com ânodo de \\
fibra de grafite \\
escovado $($ volume \\
$\left.7170 \mathrm{~m}^{2} / \mathrm{m}^{3}\right)$
\end{tabular} & 0,8 & $\begin{array}{l}\text { Logan et al. } \\
(2007)\end{array}$ \\
\hline $\begin{array}{l}\text { Carboximetilcelulose } \\
(\mathrm{CMC})\end{array}$ & $1 \mathrm{~g} / \mathrm{L}$ & $\begin{array}{l}\text { Co-culturas de } \\
\text { Clostridium } \\
\text { cellulolyticum } \\
\text { e G. } \\
\text { sulfurreducens }\end{array}$ & $\begin{array}{l}\text { Duas câmaras } \\
\text { MFC com placas } \\
\text { de grafite como } \\
\text { eletrodos }\left(16 \mathrm{~cm}^{2}\right) \\
\text { e católito cianeto } \\
\text { de ferro } \\
\end{array}$ & 0,05 & $\begin{array}{l}\text { Ren et al. } \\
(2008)\end{array}$ \\
\hline Sucrose & $2674 \mathrm{mg} / \mathrm{L}$ & $\begin{array}{l}\text { Lodo } \\
\text { anaeróbio de } \\
\text { fossa sanitária }\end{array}$ & \begin{tabular}{|l|} 
Duas câmaras de \\
MFC contendo \\
mediadores e com \\
malha de aço \\
inoxidável como \\
ânodo $\left(213,29 \mathrm{~cm}^{2}\right)$ \\
e catodo $(176,45$ \\
$\left.\mathrm{cm}^{2}\right) ; \mathrm{KMnO} 4(0,2$ \\
$\mathrm{g} / \mathrm{L})$ como católito \\
\end{tabular} & 0,19 & $\begin{array}{l}\text { Behera e } \\
\text { Ghangrekar } \\
(2009)\end{array}$ \\
\hline $\begin{array}{l}\text { Xilose e Efluentes } \\
\text { ácidos húmicos }\end{array}$ & $10 \mathrm{mM}$ & $\begin{array}{l}\text { Esgoto } \\
\text { doméstico }\end{array}$ & $\begin{array}{l}\text { Duas câmaras } \\
\text { MFC com papel } \\
\text { liso de carbono } \\
\text { como eletrodo } \\
\left(76,5 \mathrm{~cm}^{2}\right) \\
\end{array}$ & 0,06 & $\begin{array}{l}\text { Huang e } \\
\text { Angelidaki } \\
\text { (2008) }\end{array}$ \\
\hline $\begin{array}{l}\text { Esgoto artificial com } \\
\text { glucose e glutamato }\end{array}$ & $300 \mathrm{mg} / \mathrm{L}$ & $\begin{array}{l}\text { Lodo } \\
\text { anaeróbio }\end{array}$ & $\begin{array}{l}\text { Membrana menor } \\
\text { de MFC com ânodo } \\
\left(465 \mathrm{~cm}^{2}\right) \text { na parte } \\
\text { inferior e cátodo } \\
\left(89 \mathrm{~cm}^{2}\right) \text { na parte } \\
\text { superior do cilindro; } \\
\text { feltro de grafite } \\
\text { como eletrodo em } \\
\text { ambos }\end{array}$ & 0,02 & $\begin{array}{l}\text { Jang et al. } \\
(2004)\end{array}$ \\
\hline $\begin{array}{l}\text { Água residuária } \\
\text { sintética com } \\
\text { melaço e ureia }\end{array}$ & $1000 \mathrm{mg} / \mathrm{L}$ & $\begin{array}{l}\text { Mistura } \\
\text { anaeróbica de } \\
\text { esgoto de } \\
\text { planta }\end{array}$ & \begin{tabular}{|l|} 
Duas câmaras \\
MFC com fios de \\
cobre como ânodo \\
$\left(20,1 \mathrm{~cm}^{2}\right)$ e \\
câmara catódica \\
revestida de fios de \\
ouro e de cobre \\
acoplado a um \\
reator anaeróbio \\
\end{tabular} & 0,005 & $\begin{array}{l}\text { Kargi e Eker } \\
(2007)\end{array}$ \\
\hline $\begin{array}{l}\text { Esgoto alterado com } \\
\text { acetato }\end{array}$ & $1600 \mathrm{mg} / \mathrm{L}$ & $\begin{array}{l}\text { Esgoto } \\
\text { doméstico }\end{array}$ & $\begin{array}{l}\text { MFC submersível, } \\
\text { com um ânodo } \\
\text { imerso (papel } \\
\text { carbono, } 16 \mathrm{~cm}^{2} \text { ) e } \\
\text { uma câmara } \\
\text { aeróbica catódica } \\
\text { acoplada a um } \\
\text { reator anaeróbio }\end{array}$ & 0,08 & $\begin{array}{l}\text { Min e } \\
\text { Angelidaki } \\
\text { (2008) }\end{array}$ \\
\hline
\end{tabular}


A relação de diversos tipos de fontes de carbono com potencial para utilização nos sistemas bioeletroquímicos corroboram com as pesquisas de Logan (2009), que indica uma variedade de microrganismos com potencial de utilização, atrelada a uma variedade de fontes de carbono, como principal atrativo para que as MFCs sejam consideradas a tecnologia ideal para a geração de bioeletricidade a partir da biomassa renovável. Além do leque de possibilidades de uso para os elétrons no lado catódico ser atrativo para qualquer processo que envolva reação à base de redução, como é o caso da remoção de nitrato (WANG; REN, 2013).

Dessa forma, além das pesquisas envolvendo produção de energia, há o desenvolvimento de linhas de pesquisa no âmbito de aplicações no tratamento de águas residuárias e de produção de compostos de valor agregado através de processos eletroquímicos ou eletrossintéticos (KELLY; HE, 2014).

\subsubsection{Aplicação de sistemas bioeletroquímicos para remoção de nitrato}

Conforme descrito no item 3.3.2, nos processos convencionais de desnitrificação biológica ocorre uma reação de óxido-redução, na qual o nitrato é reduzido até $\mathrm{N}_{2}$ gasoso. No processo de desnitrificação bioeletroquímica, também ocorre reação de óxido-redução por microrganismos. Os aspectos que diferem entre um processo e outro correspondem:

- A velocidade de remoção do nitrato, sendo que a desnitrificação por meios convencionais, segundo as pesquisas existentes (KELLY; HE, 2014), ocorre de maneira mais lenta;

- Possibilidade de aproveitamento da amônia nos processos bioeletroquímicos;

- Possível aproveitamento energético nos processos bioeletroquímicos.

Em geral o processo consiste no uso de duas câmaras com diferenças de potenciais elétricos, os microrganismos presentes na câmara catódica oxidam os substratos orgânicos produzindo elétrons que são transportados através dos eletrodos para a câmara catódica. $\mathrm{Na}$ câmara catódica, por sua vez, ocorre a redução do nitrato através do consumo dos elétrons advindos da câmara anódica (PUIG et al., 2012). A diferença de potencial juntamente com a membrana de troca iônica promovem a passagem de prótons para a câmara catódica (Figura 12) (DU et al., 2007).

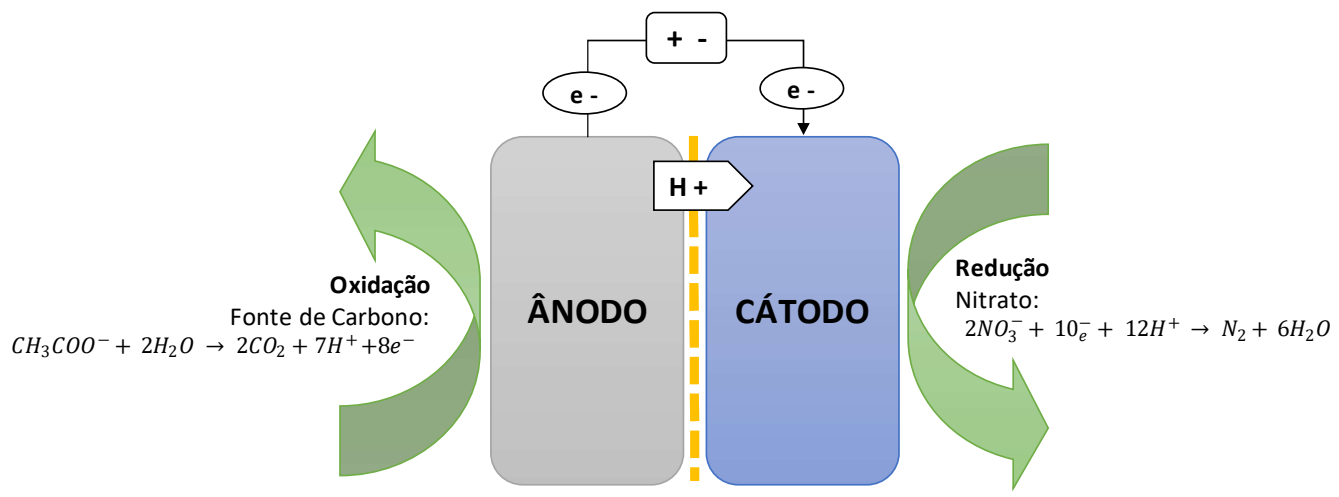

Figura 12 - Representação esquemática do sistema bioeletroquímico (Elaborada pela autora). 
A desnitrificação pelo processo bioeletroquímico pode ser efetuada tanto por bactérias autotróficas quanto por heterotróficas desnitrificantes. As bactérias autotróficas são capazes de utilizar sólidos como doadores de elétrons (KELLY; HE, 2014), o que permite que a redução do nitrato ocorra sem intermediários, representando uma expressiva vantagem em termos de energia necessária. No entanto, cabe lembrar que o processo ocorre de forma mais lenta do que a desnitrificação heterotrófica mesmo em um sistema bem controlado (VIRDIS et al., 2010).

Aplicações do processo bioeletroquímico para remoção de nitrato foram estudadas inicialmente em águas residuárias (VIRDIS et al., 2010), alcançando-se a remoção simultânea de carbono orgânico (no ânodo) e nitrato (no cátodo) (Figura 13-A). A partir dos resultados positivos da pesquisa de Virdis et al. (2008, 2009, 2010), pesquisas envolvendo sistemas bioeletroquímicos para remoção de nitrato de águas subterrâneas vieram por consequência (PUIG et al., 2012; POUS et al., 2012; ZHANG; ANGELIDAKI, 2013; TONG; HE, 2013).
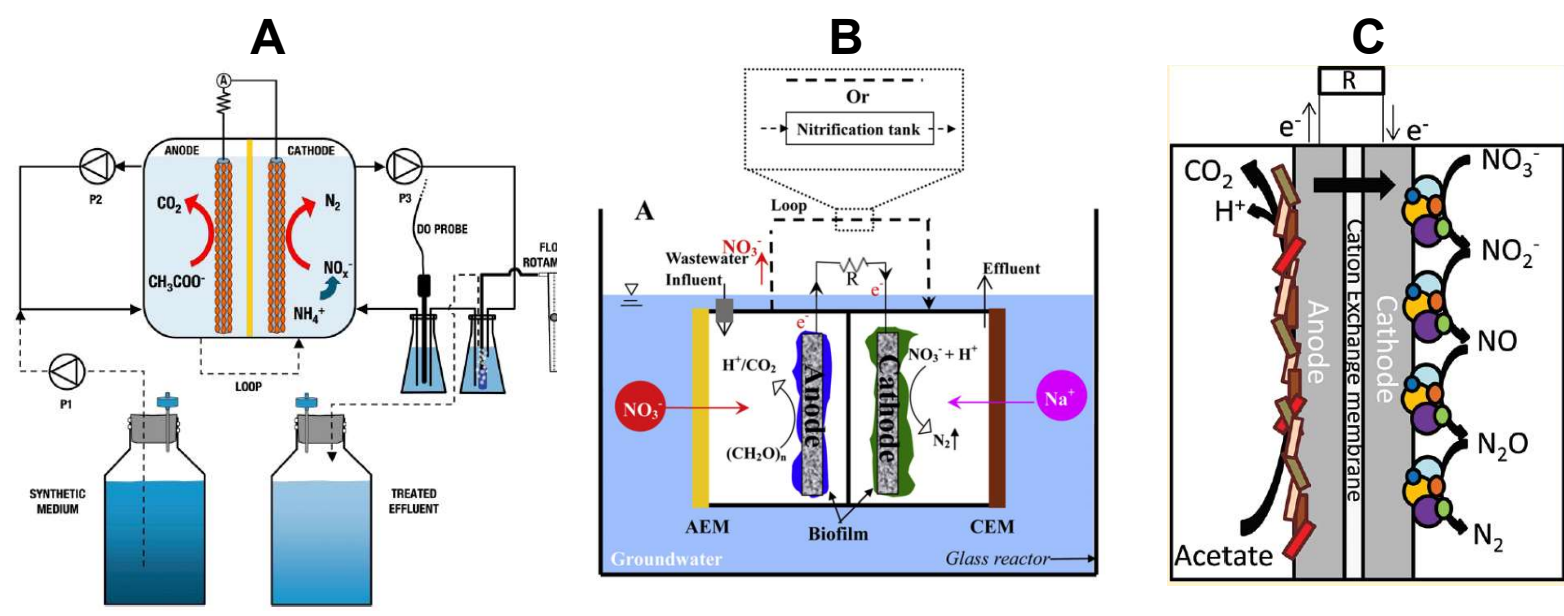

D
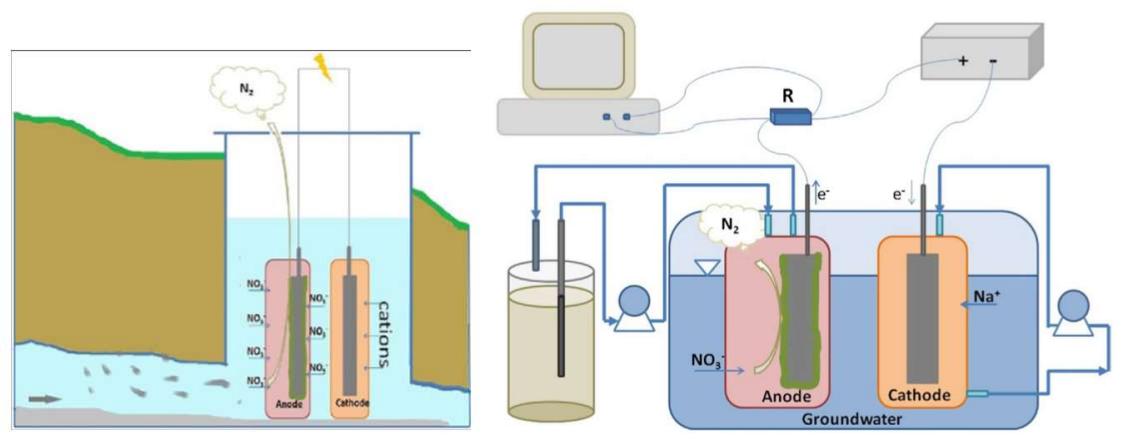

A - MFC para remoção de nitrato e carbono orgânico simultâneo em águas residuárias (VIRDIS et al., 2010)

B - SMDDC combinação de MFC e MDC para remoção de nitrato em águas subterrâneas (ZHANG; ANGELIDAKI, 2013)

C - MFC com desnitrificação autotrófica em águas subterrâneas (PUIG et al., 2012)

D - MFC in situ para remoção de nitrato em águas subterrâneas (TONG; HE, 2013)

Figura 13 - Arranjos de sistemas bioeletroquímicos para remoção de nitrato.

Zhang e Angelidaki (2013) pesquisaram uma combinação de MFCs e MDCs, intitulada de SMDDC (Submerged Microbial Desalination Denitrification Cell). Para realização do experimento, os autores utilizaram uma câmara onde ocorre o processo bioeletroquímico, submersa em outra 
câmara que simula a água subterrânea (Figura 13-B). Primeiramente, o nitrato e o sódio migrariam a partir das águas subterrâneas para o sistema bioeletroquímico, onde o ânodo e o cátodo de MDC seriam alimentados por águas residuais com a força motriz de produção de corrente. Em seguida, o nitrato fora adicionalmente transportado com o efluente do ânodo para o cátodo e, por fim, reduzido a nitrogênio gasoso na câmara catódica através da desnitrificação autotrófica, que em troca fornece a força motriz para o primeiro passo. Durante sua remoção, o nitrato ainda produziu energia para o sistema. Outra vantagem apontada pelo autor seria a diminuição dos riscos de contaminação pelos microrganismos durante o tratamento, este é o ponto chave para adoção da técnica de forma conjunta.

Puig et al. (2012) investigaram a desnitrificação através de bactérias autotróficas em águas com baixa resistência iônica (Figura 13-C), uma vez que o sistema apresentava como incerteza a eficiência de remoção nesse contexto. Foram reportados resultados positivos para desnitrificação através das bactérias autotróficas, embora tenha sido verificado o acúmulo de $\mathrm{NO}_{2}^{-}$e $\mathrm{N}_{2} \mathrm{O}$ à baixa condutividade elétrica.

Tong e He (2013) também analisaram a remoção de nitrato em águas subterrâneas, para tratamento in situ (Figura 13-D). O reator pesquisado consistiu em duas câmaras tubulares feitas de material PVC poroso envolto de membranas de troca iônica, isto é, uma câmara tubular foi envolta de uma membrana de troca catiônica e a outra câmara tubular com uma membrana de troca aniônica. O sistema foi interligado por eletrodos em ambas as câmaras, mais uma resistência de $10 \Omega$, sem aplicação de energia externa. O sistema operou em batelada e sem recirculação entre as câmaras, mas sim dentro de cada câmara.

Pous et al. (2012) deu continuidade as pesquisas de Puig et al. (2012), os autores citam como principais desafios para aplicação do processo como sendo: (i) as águas subterrâneas não contêm matéria orgânica sendo então o nitrato tratado por desnitrificação autotrófica; e (ii) a condutividade elétrica afeta o desempenho das MFCs, o que implica que o tratamento com nitrato pode ser menos eficiente em águas com baixa força iônica, tais como as águas subterrâneas. Os resultados obtidos por Pous et al. (2012) mostram que as águas subterrâneas contaminadas com nitrato podem ser tratadas com sucesso usando MFCs, mesmo com a baixa condutividade presentes em águas subterrâneas. As águas subterrâneas foram tratadas através da redução do nitrato na câmara catódica, que resultaram numa diminuição da concentração de nitrato de 28,32 $\pm 6,15$ para $12,14 \pm 3,59 \mathrm{mg} \mathrm{N}-\mathrm{NO}_{3}{ }^{-} \mathrm{L}^{-1}$, e baixo acumulo de nitrito $\left(0,14 \pm 0,13 \mathrm{mg} \mathrm{N}-\mathrm{NO}_{2} \cdot \mathrm{L}^{-1}\right.$ no efluente), no entanto, houveram indícios de acumulação de óxido nitroso no sistema.

Os estudos existentes apresentaram resultados positivos para remoção de nitrato pelo sistema bioeletroquímico (Tabela 6), operando em fluxo continuo ou batelada, o modelo de proposto por Zhang e Angelidaki (2013) apresentaram maior eficiência de remoção de nitrato (92\%), no entanto um dos maiores tempos de detenção hidráulica (TDH). Os resultados de Tong e He (2013) para o teste de aplicação de corrente não atingiram uma melhor eficiência de 
remoção se comparados aos dos experimentos de Virdis et al. (2010), que também operaram um sistema em batelada e não aplicaram corrente externa. No entanto Virdis et al. (2010) pesquisaram remoção de nitrato em águas residuárias, enquanto que Tong e He (2013) em águas subterrâneas.

Tabela 6 - Síntese de resultados obtidos com sistemas bioeletroquímicos para remoção de nitrato.

\begin{tabular}{|c|c|c|c|c|c|c|}
\hline Parâmetros & $\begin{array}{l}\text { Virdis et } \\
\text { al. }(2010)^{1}\end{array}$ & $\begin{array}{l}\text { Puig et al. } \\
(2011)^{2}\end{array}$ & \begin{tabular}{|l} 
Zhang e \\
Angelidaki \\
(2013)
\end{tabular} & \begin{tabular}{|l} 
Pous et \\
al. \\
$(2013)^{5}$
\end{tabular} & $\begin{array}{l}\text { Tong e He } \\
\text { (2013) 0,0V }\end{array}$ & $\begin{array}{l}\text { Tong e He } \\
(2013) 0,8 V^{7}\end{array}$ \\
\hline $\begin{array}{l}\text { Taxa de aplicação } \\
\text { Anodo (mL/min) }\end{array}$ & 0,49 & 1,07 & 0,025 & 0,84 & -8 & -8 \\
\hline $\begin{array}{l}\text { Taxa de aplicação } \\
\text { Catodo (mL/min) }\end{array}$ & 0,49 & 1 & -4 & 0,85 & -8 & -8 \\
\hline $\begin{array}{l}\text { Tempos de Detenção } \\
\text { Hidráulica TDH (h) }\end{array}$ & 6,86 & 8,5 & 12 & 10,3 & 25 & 25 \\
\hline $\mathrm{N}-\mathrm{NO}_{3}-(\mathrm{mg} / \mathrm{L})$ & 209,04 & 15,26 & 10 & $\begin{array}{l}28,32 \pm \\
6,15\end{array}$ & 24 & 24 \\
\hline Fluxo & Batelada & Contínuo & Batelada & Contínuo & Batelada & Batelada \\
\hline $\begin{array}{l}\text { Remoção de nitrato } \\
\left(\mathrm{Kg} \mathrm{N} / \mathrm{m}^{3} \text {.dia }\right)\end{array}$ & $\begin{array}{l}0,117 \pm \\
0,001\end{array}$ & $\begin{array}{l}0,021 \pm \\
0,002\end{array}$ & 0,870 & 0,051 & $\begin{array}{l}0,154 \pm \\
0,024\end{array}$ & \begin{tabular}{|l|}
$0,208 \pm$ \\
0,013
\end{tabular} \\
\hline $\begin{array}{l}\text { Eficiência de } \\
\text { remoção (\%) }\end{array}$ & $76,8 \pm 0,5$ & 80,2 & 92 & 64 & 57,2 & 77,3 \\
\hline $\begin{array}{l}\text { Eficiência de } \\
\text { Coulomb (\%) }\end{array}$ & $77,4 \pm 2,2$ & 73 & 66,4 & 80 & $14,6 \pm 0,2$ & $36,2 \pm 5,0$ \\
\hline $\begin{array}{l}\text { Densidade de } \\
\text { corrente }\end{array}$ & - & $\begin{array}{l}13,0 \pm 0,3 \\
\mathrm{~A} / \mathrm{m}^{3} \mathrm{CC}^{3}\end{array}$ & $6,2 \mathrm{~A} / \mathrm{m}^{2}$ & $8,73 \mathrm{~A} / \mathrm{m}^{3}$ & $20,88 \mathrm{~A} / \mathrm{m}^{3}$ & $28,2 \mathrm{~A} / \mathrm{m}^{3}$ \\
\hline
\end{tabular}

1 - Sistema removeu nitrato em aguas residuárias, resultados apresentados consideram os ensaios: Relação COD/N $(g / g)=1,88$

$\pm 0,01$, maior valor obtido dentre os ensaios realizados na pesquisa

2 - Resultados apresentados correspondem ao Teste 5

3 - Câmara catódica

4 - Cátodo é alimentado pela pressão exercida no sistema piloto submerso em $500 \mathrm{~mL}$ de agua sintética.

5 - Resultados apresentado correspondem ao Teste do período 84-97 dias

6 - Resultados obtidos no teste sem aplicação de tensão externa $(0,0 \mathrm{~V})$

7 - Resultados obtidos no teste com aplicação de tensão externa $(0,8 \mathrm{~V})$

8 - Taxa de aplicação do sistema é realizado por pressão exercida no sistema piloto submerso em $400 \mathrm{~mL}$ de solução sintética

Os subitens a seguir apresentam o detalhamento dos principais componentes envolvidos no sistema bioeletroquímico para remoção de nitrato, tais como características das águas subterrâneas, fontes de carbono, microrganismos utilizados, membrana de troca iônica, circuito elétrico, recirculação entre as câmaras, TDH, parâmetros de controle, entre outros.

\subsubsection{1 Água subterrânea sintética}

Alguns estudos utilizam-se de soluções sintéticas para simular a composição das águas subterrâneas, de modo a avaliar a eficiência do tratamento proposto minimizando possíveis interferências advindas de compostos que possam estar presentes nas águas subterrâneas.

Puig et al. (2012) e Pous et al. (2013) utilizaram águas subterrâneas da Vila Navata

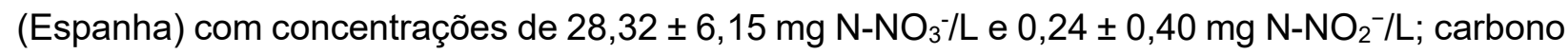

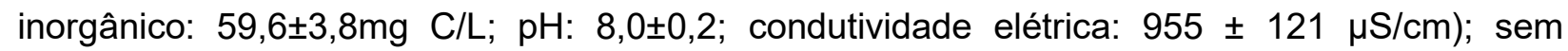


concentrações de amônio $\left(\mathrm{N}^{-\mathrm{NH}_{4}}{ }^{+}\right.$). Além disso, Puig et al. (2012) citam a utilização de uma solução na alimentação da câmara catódica para iniciar o processo: $244 \mathrm{mg} \mathrm{NaHCO} / \mathrm{L}, 100 \mathrm{mg}$ $\mathrm{NaNO}_{3} / \mathrm{L}, 545 \mathrm{mg} \mathrm{NaH} \mathrm{PO}_{4} \cdot 2 \mathrm{H}_{2} \mathrm{O} / \mathrm{L}, 240 \mathrm{mg} \mathrm{KH} \mathrm{PO}_{4} \cdot 2 \mathrm{H}_{2} \mathrm{O} / \mathrm{L}, 2,8 \mathrm{mg} \mathrm{CaCl} \cdot 2 \mathrm{H}_{2} \mathrm{O} / \mathrm{L}, 18 \mathrm{mg}$ $\mathrm{MgSO}_{4} \cdot 7 \mathrm{H}_{2} \mathrm{O} / \mathrm{L}, 2,6 \mathrm{mg} \mathrm{KCl} / \mathrm{L}$, e $0,1 \mathrm{~mL} / \mathrm{L}$ solução de microelementos. O bicarbonato de sódio em contato com a água libera o dióxido de carbono, servindo como fonte de carbono para as bactérias desnitrificantes autotróficas.

Zhang e Agelidaki (2013) utilizaram uma solução preparada com adição de nitrato de $20 \mathrm{mg} \mathrm{N}-\mathrm{NO}_{3}-/ \mathrm{L}$ ) e solução mineral $0,1 \mathrm{~mL}$ de água da torneira com uma condutividade de cerca de $900 \mu \mathrm{S} / \mathrm{cm}$. A proporção C:N:P da água subterrânea sintética preparada por Zhang e Agelidaki (2013) foi de cerca de 1:667:1. Já Tong e He (2013) utilizaram uma solução preparada com água de torneira dissolvendo nitrato de sódio $\left(\mathrm{NaNO}_{3}\right)$.

\subsubsection{Fonte de Carbono}

Conforme já citado anteriormente, a desnitrificação por meio de agentes microbiológicos necessita da presença de uma fonte de carbono. Em geral, as águas subterrâneas não apresentam altas concentrações de matéria orgânica, o que faz com que esta fonte de carbono deva ser artificialmente fornecida.

Mohseni-Bandpi et al. (2013) analisaram a performance de diferentes fontes de carbono no processo de desnitrificação biológica em águas subterrâneas, a pesquisa focou no metanol, etanol e ácido acético. Segundo os autores, apesar do metanol ser a fonte de carbono mais disponível, podem surgir efeitos tóxicos quando da redução incompleta no $\mathrm{NO}_{3}{ }^{-}$para $\mathrm{N}_{2}$ gasoso. O ácido acético obteve melhores resultados na remoção de nitrato e formação de subprodutos. O etanol se apresentou em segundo lugar na lista, tendo seu uso em ascensão.

Estudos para remoção de nitrato utilizaram o acetato de sódio como fonte de carbono juntamente com o preparo de soluções de maneira a satisfazer o desenvolvimento das bactérias desnitrificantes para o processo. Zhang e Angelidaki (2013) utilizaram uma solução com $800 \mathrm{mg} \mathrm{CH}{ }_{3} \mathrm{COONa} / \mathrm{L}$, Pous et al. (2013) e Puig et al. (2012) com 450 mg CH${ }_{3} \mathrm{COONa} / \mathrm{L}$ e Tong e He (2013) com $500 \mathrm{mg} \mathrm{CH} \mathrm{CHOONa}_{3}$.

Puig et al. (2012) citam que uma das vantagens do uso do sistema bioeletroquímico é a possibilidade do uso de bactérias autotróficas desnitrificantes no processo. No entanto, esses autores assim como Virdis et al. (2010) também citam que a desnitrificação por bactérias autotróficas fora constatada com alta condutividade elétrica como é o caso de águas residuárias (2.000-11.000 $\mu \mathrm{S} / \mathrm{cm})$. Condições de baixa condutividade elétrica, como é característico de águas subterrâneas $(<1000 \mu \mathrm{S} / \mathrm{cm})$, podem criar limitações no processo de desnitrificação no sistema (PUIG et al., 2012). 


\subsubsection{Microrganismos}

Como os microrganismos são os agentes desnitrificantes do processo, o controle das condições ótimas de seu desenvolvimento é um dos principais desafios da operação do sistema bioeletroquímico.

Virdis et al. (2010), Puig et al. (2012) e Pous et al. (2013) realizaram a inoculação de seus experimentos através de processos bioeletroquímicos existentes já operantes.

Zhang e Agelidaki (2013) e Tong e He (2013) utilizaram microrganismos presentes em sistemas de tratamento de águas residuárias por processo de lodos ativados que continham bactérias desnitrificantes.

Os microrganismos usualmente utilizados em sistemas bioeletroquímicos para geração de energia correspondem àqueles relacionados na Tabela 4. Para remoção de nitrato não necessariamente são empregados os mesmos microrganismos, a menos que também sejam considerados agentes desnitrificantes como o caso da Geobacter metallireducens.

\subsubsection{Câmaras anódica e catódica}

A composição dos sistemas bioeletroquímicos através de duas câmaras com diferenças de potenciais elétricos é uma das principais características do processo. Segundo Du et al. (2007), os principais materiais utilizados para elaboração das câmaras são vidro, policarbonato e acrílico. Zhang e Agelidaki (2013) utilizaram policarbonato para construção das câmaras, Puig et al. (2012) e Pous et al. (2013), metacrilato, enquanto Tong e He (2013), tubos de PVC poroso. Não foi identificado uma justificativa para uso de um material em detrimento a outro, desde que não sofra reação com as soluções propostas para o sistema de tratamento.

\subsubsection{Membrana de troca iônica}

A membrana de troca iônica tem a função de promover o transporte de prótons e outras espécies catiônicas para a câmara catódica, e ao mesmo tempo impede a difusão de oxigênio da câmara anódica.

Estudos realizados por Liu e Logan (2004) avaliaram um sistema bioeletroquímico utilizando a membrana de troca iônica e na ausência desta, sendo relatado como principal característica o alto consumo de substrato (esgoto doméstico) na câmara anódica. Além disso, foi reportada uma maior difusão de oxigênio para a câmara catódica, diminuindo a eficiência da desnitrificação. Para remoção de nitrato em águas subterrâneas, os resultados apresentados por Liu e Logan (2004) sugerem não ser recomendada a retirada da membrana no processo, visto que águas subterrâneas não apresentam abundância em substrato (fonte de carbono) e a transferência de oxigênio para o cátodo não é interessante para o desenvolvimento de bactérias anaeróbias desnitrificantes. 
Os estudos existentes propostos para remoção de nitrato (Tabela 7) utilizaram membranas de troca catiônica ou sistemas de tratamentos que utilizavam duas membranas (catiônica e aniônica) no processo. Dois principais modelos de membranas são geralmente utilizados (Nafion e Ultrex), sendo a membrana Nafion tida como principal referência. Rozendal et al. (2006) realizaram testes com as membranas Nafion e constaram que apesar de excelentes condutoras de prótons, sua aplicação em sistemas bioeletroquímicos tem resultado em alguns problemas de operação, indicando que o uso dessa membrana não é insubstituível.

Tabela 7 - Membranas de troca iônica utilizadas para tratamento de nitrato.

\begin{tabular}{|l|l|}
\hline Autores & Membrana \\
\hline Virdis et al. (2010) & $\begin{array}{l}\text { Membrana de troca catiônica (CEM) (Ultrex CMI-7000, Membrane } \\
\text { International, USA) }\end{array}$ \\
\hline Zhang e Angelidaki (2013) & $\begin{array}{l}\text { Membrana de troca aniônica (AMI 7001, Membrane international, USA) e } \\
\text { Membrana de troca catiônica (CMI 7000, Membrane international, USA) }\end{array}$ \\
\hline Pous et al. (2013) & Membrana de troca catiônica (CEM, Nafion 117, DuPont, USA) \\
\hline Puig et al. (2012) & Membrana de troca catiônica (CEM, Nafion 117, DuPont, USA) \\
\hline Tong e He (2013) & $\begin{array}{l}\text { Membrana de troca catiônica e aniônica (Membrane International Inc., } \\
\text { Ringwood, USA). }\end{array}$ \\
\hline
\end{tabular}

\subsubsection{Eletrodos e meio de crescimento bacterianos}

A corrente elétrica é gerada espontaneamente através da transferência de elétrons entre um par de eletrodos intermediada por microrganismos: no ânodo ocorre a reação de oxidação onde elétrons são liberados e no cátodo, a redução, onde elétrons são recebidos.

Pesquisas em eletrodos de diferentes materiais foram realizadas por Du et al. (2007) visando investigar seu impacto na performance dos sistemas bioeletroquímicos. Os autores indicaram o grafite, feltro de grafite, papel carbono, tecido-carbono, platina $(\mathrm{Pt})$, platina preta $(\mathrm{Pt}$ black) e carbono vítreo reticulado (RVC) como os principais materiais utilizados, sendo a platina e a platina preta reportadas como melhores condutores, mas seu uso não é muito comum devido aos elevados custos. Estudos específicos voltados à remoção de nitrato empregam eletrodos constituídos de grafite (VIRDIS et al., 2010; PUIG et al., 2012; POUS et al., 2013), papel carbono (ZHANG; AGELIDAKI, 2013) e tecido de carbono (TONG; HE, 2013).

Apesar de parecer lógico que uma maior área possa facilitar as reações no eletrodo, Oh et al. (2004) e Oh e Logan (2006) concluíram que a variação da área tem um pequeno efeito no processo. E mesmo com tais considerações, Virdis et al. (2010), Puig et al. (2012) e Pous et al. (2013) utilizaram grafite granular nas câmaras anódica e catódica - o mesmo material dos eletrodos - para crescimento bacteriano aderido e aumento das reações. Zhang e Angelidaki (2013) utilizaram um processo externo de nitrificação que empregou contas de vidro de $1 \mathrm{~mm}$ de diâmetro como meio de crescimento bacteriano. 


\subsubsection{Circuito elétrico}

O circuito elétrico no sistema possui diferentes funções dependendo do objetivo do estudo, podendo operar em sistema aberto, ou seja, sem o fornecimento de uma fonte de tensão externa, ou em sistema fechado, através da aplicação de energia.

Tong e He (2013) investigaram os efeitos na aplicação de energia externa sobre a remoção de nitrato. A partir da variação da tensão entre $0 \mathrm{~V}, 0,5 \mathrm{~V}, 0,8 \mathrm{~V}$ e $1 \mathrm{~V}$, constatou-se que, dadas as condições do processo, a remoção de nitrato e a produção de energia foram mais eficientes com a aplicação de 0,8 V. Segundo os autores, esta relação ainda não está totalmente clara, e pode estar atrelada a fatores externos.

\subsubsection{Recirculação entre as câmaras}

Segundo Puig et al. (2012), a recirculação entre as câmaras do sistema bioeletroquímico visa manter o meio em condições homogêneas, evitar gradientes de concentração e evitar a obstrução no bombeamento devido ao crescimento bacteriano.

Virdis et al. (2010) adotaram recirculação de $200 \mathrm{~mL} / \mathrm{min}$ para um reator com volume total de 400 mL, enquanto Puig et al. (2012) e Pous et al. (2013) aplicaram vazão de 72,91 mL/min para volume total de $1050 \mathrm{~mL}$. Zhang e Angelidaki (2013) promoveram a recirculação entre as câmaras através de uma conexão realizada por tubos de plástico e borracha, sugerindo não haver uma vazão controlada.

\subsubsection{Tempo de Detenção Hidráulica (TDH)}

O TDH é um dos parâmetros mais importantes em processos de tratamentos biológicos, pois está diretamente relacionado à eficiência do tratamento, visto que as reações bioeletroquímicas ocorrem a uma certa velocidade influenciadas por condições ambientais tais como $\mathrm{pH}$, temperatura, presença de nutrientes, tempo de contato entre fonte de carbono e biomassa, dentre outras.

As dimensões das câmaras anódica e catódica são elaboradas com base no tempo de detenção hidráulica (TDH) adotado para o sistema. Virdis et al. (2010) operaram um sistema com TDH de 6,86 h e Zhang e Angelidaki (2013) investigaram com maior detalhe sua influência no sistema bioeletroquímico variando o TDH em 6, 12 e 18 h. Os autores concluíram que há maior remoção de matéria orgânica em TDH de 6 h, e remoção de nitrato em TDH de 12 h.

\subsubsection{Parâmetros de avaliação do sistema bioeletroquímico}

Segundo Logan et al. (2006), o desempenho geral de um sistema bioeletroquímico é avaliado principalmente através de potência e eficiência de Coulomb. No entanto, quando o sistema objetiva tratamento, neste caso de águas residuárias, esses autores citam a importância de avaliar o desempenho global em termos de demanda bioquímica de oxigênio (DBO), ou a 
demanda química de oxigênio (DQO), ou a remoção de carbono orgânico total (COT), remoção de sólidos suspensos contra sólidos dissolvidos, e remoção de nutrientes.

Nos estudos com foco em remoção de nitrato em águas subterrâneas, é usualmente avaliado a remoção de nitrato, eficiência de Coulomb, geração de $\mathrm{N}_{2} \mathrm{O}$ e parâmetros relacionados ao objetivo da pesquisa, como influência da condutividade elétrica no processo de remoção e sensibilidade do TDH. O monitoramento de outros parâmetros como pH e temperatura também recomendável já que são influem na performance das bactérias desnitrificantes.

\section{Eficiência de remoção do nitrato}

Puig et al. (2012), Pous et al. (2013) e Tong e He (2013) calcularam a eficiência da remoção de nitrato aos moldes tradicionais, através da diferença da concentração do afluente e efluente.

$$
E R_{N-N O_{3}^{-}}=\frac{N_{\text {afluente }}-N_{\text {efluente }}}{N_{\text {afluente }}}
$$

Equação 8

Sendo:

$E R_{N-N O_{3}^{-}}=$eficiência da remoção de nitrato (\%)

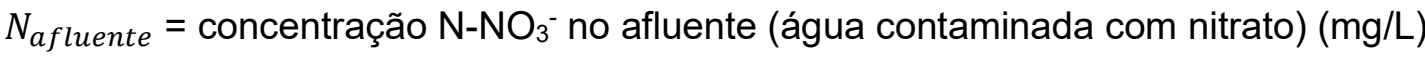

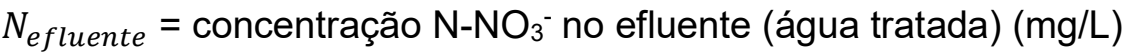

Kelly e He (2014) realizaram um levantamento da taxa de remoção (Tabela 8) dos processos de desnitrificação facilitando a comparação da performance dos mecanismos de remoção.

Tabela 8 - Taxas de remoção de N-NO ${ }^{-}$(KELLY; HE, 2014).

\begin{tabular}{|l|l|l|}
\hline Mecanismo de remoção & Taxa de remoção $\mathbf{~ k g / m}$.dia) & Referências \\
\hline N-BD & 0,51 & Virdis et al. (2008) \\
\hline N-BD & 0,013 & Xie et al. (2011) \\
\hline N-BD & 0,008 & Cha et al. (2009) \\
\hline N-BD & 0,003 & Zhang e He (2012b) \\
\hline N-BD & 0,013 & Zhang e He (2012a) \\
\hline N-BD & $0,037-0,199$ & Zhang e He (2013) \\
\hline N-BD & 0,042 & Ryu et al.(2013) \\
\hline AR & 0,132 & Kuntke et al.(2012) \\
\hline AR & 0,52 & Wu e Modin $(2013)$ \\
\hline AR & 0,061 & Haddadi et al.(2013) \\
\hline SND (cátodo) & 0,0043 & Yu et al.(2011) \\
\hline SND (cátodo aéreo) & 0,049 & Yan et al.(2012) \\
\hline SND (cátodo) & 0,1 & Virdis et al.(2010) \\
\hline SND (cátodo) & 0,024 & Virdis et al.(2010) \\
\hline ND convencional & $0,05-4$ & Wang et al.(2009) \\
\hline ANNAMOX & $6-12$ & Wang et al.(2009) \\
\hline
\end{tabular}

N-BD: Nitrificação e desnitrificação bioeletroquímico; AR: recuperação de amônia; SND: Nitrificação simultânea e desnitrificação bioeletroquímica; e ND: Nitrificação e Desnitrificação 


\section{Eficiência de Coulomb}

Logan et al. (2006) descreve a eficiência de Coulomb como a razão do total de Coulombs efetivamente transferidos para o ânodo do substrato (ou fonte de carbono), e um máximo de Coulombs possíveis, tendo como referencial teórico o consumo total de substrato produzindo corrente. Os Coulombs totais obtidos são determinados pela integração da corrente ao longo do tempo. O cálculo da eficiência de Coulomb $\left(\epsilon_{C b}\right)$, expressa em porcentagem, para um sistema bioeletroquímico em modo descontínuo de alimentação (batelada) é expresso como:

$$
\epsilon_{C b}=\frac{M \int_{0}^{t} b_{1} I t}{F b v_{A n} \Delta D Q O}
$$

Onde:

$M=32$, peso molecular do oxigênio

$I=$ corrente elétrica $(\mathrm{A})$

$F=$ constante de Faraday $(96485 \mathrm{C} / \mathrm{mol})$

$b=4$, número de elétrons por mol de oxigênio

$v_{A n}=$ volume líquido na câmara anódica

$\triangle D Q O=$ conversão da $\mathrm{DQO}$ no tempo $t_{b}$

Para um fluxo contínuo, Logan et al. (2006) calcularam a eficiência de Coulomb com base na corrente gerada sob condições estáveis:

$$
\epsilon_{C b}=\frac{M I}{F b q \Delta D Q O}
$$

Equação 10

Onde $q$ é a vazão afluente no sistema

Virdis et al. (2010) e Pous et al. (2013) utilizaram a metodologia de avaliação da eficiência de Coulomb definida por Virdis et al. (2008) para propor uma equação específica para avaliação da redução no nitrato e nitrito. A eficiência de Coulomb é calculada através da relação da taxa da passagem de corrente no sistema e a corrente teórica estimada baseada nos compostos nitrogenados oxidados removidos no cátodo.

$$
\mathcal{E} N O x=\frac{I}{\eta \Delta C_{N O X} q F} \times 100
$$

Onde:

$\mathcal{E} N O x=$ Eficiência de Coulomb para nitrato $(\%)$

$\eta=$ número de elétrons que pode ser aceito por $1 \mathrm{~mol}$ de composto nitrogenado oxidado presente no cátodo, assumindo que $\mathrm{N}_{2}$ é o produto final, sendo 5 para nitrato e 3 para nitrito $\left(\mathrm{e}^{-} / \mathrm{mol}\right)$ $\Delta C_{N O x}=$ diferença entre a concentração de $\mathrm{N}-\mathrm{NO}_{3}{ }^{-}$do afluente e efluente catódico $(\mathrm{mol} / \mathrm{L} \mathrm{N}$ $\mathrm{NO}_{3}{ }^{-}$) 
A variável $\eta$ na equação representa a transferência de elétrons no processo de desnitrificação, previamente discutido no item 3.2.2.

Tong e He (2013) propuseram outra metodologia para cálculo da eficiência de Coulomb, assumindo dois tipos de formas de avaliação: a primeira com base na DQO no compartimento anódico (Equação 12) e a segunda com base na concentração de nitrato (Equação 13). A primeira equação assume consumo de 4 mols de elétrons/mol de DQO, e a segunda assume consumo de 5 mols de elétrons $/ \mathrm{mol}$ de nitrato removido.

$$
\begin{aligned}
& C E_{C}=\frac{Q_{\text {output }}}{Q_{\text {input }}}=\frac{\sum I t}{F \times D Q O_{\text {removida }} \times 4} \\
& C E_{N}=\frac{Q_{\text {output }}}{Q_{\text {input }}}=\frac{\sum I t}{F \times N_{\text {removido }} \times 5}
\end{aligned}
$$

Onde:

$C E_{C}=$ eficiência de Coulomb baseada no substrato orgânico (\%)

$C E_{N}=$ eficiência de Coulomb baseada no nitrato (\%)

$Q_{\text {output }}=$ carga produzida $(\mathrm{V})$

$Q_{\text {input }}=$ carga total disponível no substrato $(\mathrm{V})$

$t=$ tempo em segundos

$D Q O_{\text {removida }}=\mathrm{DQO}$ removida pelo sistema bioeletroquímico em um período de tempo $(\mathrm{mg} / \mathrm{L})$

$N_{\text {removido }}=$ quantidade de nitrato removido em um determinado período de tempo

Além de tais referências, Clauwaert et al. (2007) e Puig et al. (2012) em suas pesquisas empregaram uma equação denominada por Clauwaert et al. (2007) como Densidade Volumétrica de Corrente (D), que considera o processo de desnitrificação como sendo completo:

$$
D=\frac{I M}{F \eta} \frac{86400 s d^{-1}}{1000 \mathrm{~g} \mathrm{~kg}^{-1}}=2,507 \times 10^{-3} I
$$

Sendo:

I = Densidade volumétrica de corrente $\left(\mathrm{A} / \mathrm{m}^{3}\right)$

$M=$ Massa molar do nitrogênio $(14 \mathrm{~g} / \mathrm{mol} \mathrm{N})$

\section{Quantificação dos compostos nitrogenados gasosos}

No processo de desnitrificação, pode ocorrer a redução incompleta de $\mathrm{NO}_{3}{ }^{-}$a $\mathrm{N}_{2}$ gerando $\mathrm{N}_{2} \mathrm{O}$ e/ou NO. Para quantificação desses gases é comum realizar medições analíticas através de microsensores, análises que são complexas e de restrito acesso no Brasil.

Virdis et al. (2009) realizaram medições de $\mathrm{N}_{2} \mathrm{O}$ juntamente com a série nitrogenada, e através de análises estatísticas, elaboraram uma relação de porcentagem de $\mathrm{N}_{2} \mathrm{O}$ gerado no 
processo de desnitrificação através do sistema bioeletroquímico com a diferença de potencial no sistema, fechando a estequiometria do nitrogênio.

Puig et al. (2012) e Pous et al. (2013) estimaram o $\mathrm{N}_{2} \mathrm{O}$ de maneira indireta através da correlação da Eficiência de Coulomb obtida em suas pesquisas com as estimativas de $\mathrm{N}_{2} \mathrm{O}$ obtidas por Virdis et al. (2009).

A quantificação de NO no processo bioeletroquímico foi considerado desprezível nos estudos de Virdis et al. (2009), Puig et al. (2012) e Pous et al. (2013), Zhang e Angelidaki (2013).

\section{Densidade de potência e corrente}

Logan et al. (2006) propôs a equação 15 para estimativa de densidade de potência, esta pode ser medida somente através da área do ânodo, devido à reação biológica produtora de energia excedente, como pode ser medida considerando o volume total do reator, quando este possui uma área de difícil quantificação, como é o caso de reatores com material granular como meio de suporte.

$$
P_{V}=\frac{E_{c e l l}^{2}}{V R_{e x t}}
$$

Onde:

$P_{V} \quad=$ Densidade de Potência $\left(\mathrm{W} / \mathrm{m}^{3}\right)$

$R_{\text {ext }}=$ Resistencia externa $(\Omega)$

$E_{\text {cell }}^{2}=$ Tensão $^{2}(\mathrm{~V})$, expressa pela Lei de Ohm

$V \quad=$ Volume total do reator $\left(\mathrm{m}^{3}\right)$

Puig et al. (2012), Pous et al. (2013) e Zhang e Angelidaki (2013) propuseram uma relação semelhante, utilizando os valores de potência ou corrente divididos pelo volume líquido do cátodo, a unidade de medida é expressa então em $\mathrm{A} / \mathrm{m}^{3}$.

$$
C_{V}=\frac{E_{c e l l}^{2}}{V R_{\text {ext }}}
$$

Onde:

$C_{V} \quad=$ Densidade de Corrente $\left(\mathrm{mA} / \mathrm{m}^{3}\right)$

$R_{\text {ext }}=$ Resistencia externa $(\Omega)$

$E_{\text {cell }}^{2}=$ Corrente $^{2}(\mathrm{~mA})$

$V \quad=$ Volume total do cátodo (material granular) $\left(\mathrm{m}^{3}\right)$ 


\section{MATERIAIS E MÉTODOS}

A implementação do sistema bioeletroquímico desse estudo bem como seu monitoramento foram realizados no Laboratório de Saneamento da Escola Politécnica da Universidade de São Paulo (Poli-USP), frutos de uma parceria entre o Instituto de Geociências (IGc-USP) e o Departamento de Saneamento da Poli-USP. As análises laboratoriais também foram conduzidas no Laboratório de Saneamento. A montagem do reator foi realizada em parceria com a Fundação Centro Tecnológico de Hidráulica (FCTH-USP). A membrana de troca iônica foi fornecida pela Membranes International Inc.

\subsection{Descrição do sistema bioeletroquímico}

O experimento foi montado em escala de teste de bancada visando avaliar a operação de um sistema bioeletroquímico adaptado às condições climáticas e características regionais. Diversas literaturas foram consultadas (item 3.3.4) a fim de se definir os materiais e métodos mais adequados para desenvolvimento dessa pesquisa.

Um tanque de material acrílico com volume total de $3150 \mathrm{~cm}^{3}$ foi construído com uma canaleta para encaixar uma membrana de troca iônica (CEM) modelo Ultrex CMI-7000 da Membrane International Inc., formando assim dois compartimentos, o anódico e o catódico com volume total de 1350 e $1800 \mathrm{~cm}^{3}$ respectivamente, estas dimensões totais contemplam a borda livre do reator, o volume total efetivamente utilizado no sistema foi de $913,5 \mathrm{~cm}^{3}$ no ânodo e de $1131 \mathrm{~cm}^{3}$ no cátodo.

Tanto a câmara anódica quanto a catódica foram parcialmente preenchidas $(50 \%$ do volume total efetivo) com grafite granular modelo SUPERGRAF 08 (comercializado pela Graphitas Com. e Rep. Ltda, Brasil) com diâmetro entre 1,0 - 1,7 mm.

Dois eletrodos de grafite em formato de "placa" $(200 \times 20 \times 5$ mm, da Graphitas Com. e Rep. Ltda, Brasil) foram ligados a uma resistência $(5 \Omega)$ e uma fonte regulável de tensão para fechar o circuito elétrico. O lado anódico do sistema foi vedado de forma a promover vácuo para o líquido fluir pela membrana.

Os compartimentos anódico e catódico foram inoculados com um consórcio microbiano "lodo biológico" de uma estação de tratamento de esgoto doméstico da SABESP que opera com remoção de material orgânico e nutrientes (Nitrogênio e Fósforo). Foi adicionado um volume de aproximadamente $30 \%$ do volume útil de cada câmara e aplicada uma concentração de sólidos em suspensão voláteis (SSV) do inóculo de aproximadamente $3,0 \mathrm{~g} / \mathrm{L}$.

Após a inoculação, a solução de água subterrânea sintética foi bombeada para o compartimento catódico em fluxo ascendente. A fonte de carbono foi bombeada também em fluxo ascendente para o compartimento anódico. A alimentação do sistema pelas injeções de água subterrânea sintética e de fonte de carbono foi iniciada com a aplicação da maior vazão 
reportada em estudos de literatura (item 3.3.4.9), de 1,44 L/dia (1 $\mathrm{mL} / \mathrm{min}$ ) para cada compartimento (anódico e catódico) e conforme o andamento dos testes, foi variada até $5,76 \mathrm{~L} /$ dia (4 mL/min). Um loop de recirculação interna de $105 \mathrm{~L} /$ dia (73 $\mathrm{mL} / \mathrm{min}$ ) foi colocado entre os compartimentos para manter boas condições de mistura, evitar gradientes de concentração e o entupimento da matriz granular, conforme descrito no item 3.3.4.8. O sistema operou em temperatura ambiente $\left(22\right.$ a $\left.25^{\circ} \mathrm{C}\right)$. A Figura 14 mostra a configuração e os componentes do sistema de MFC desenvolvido.

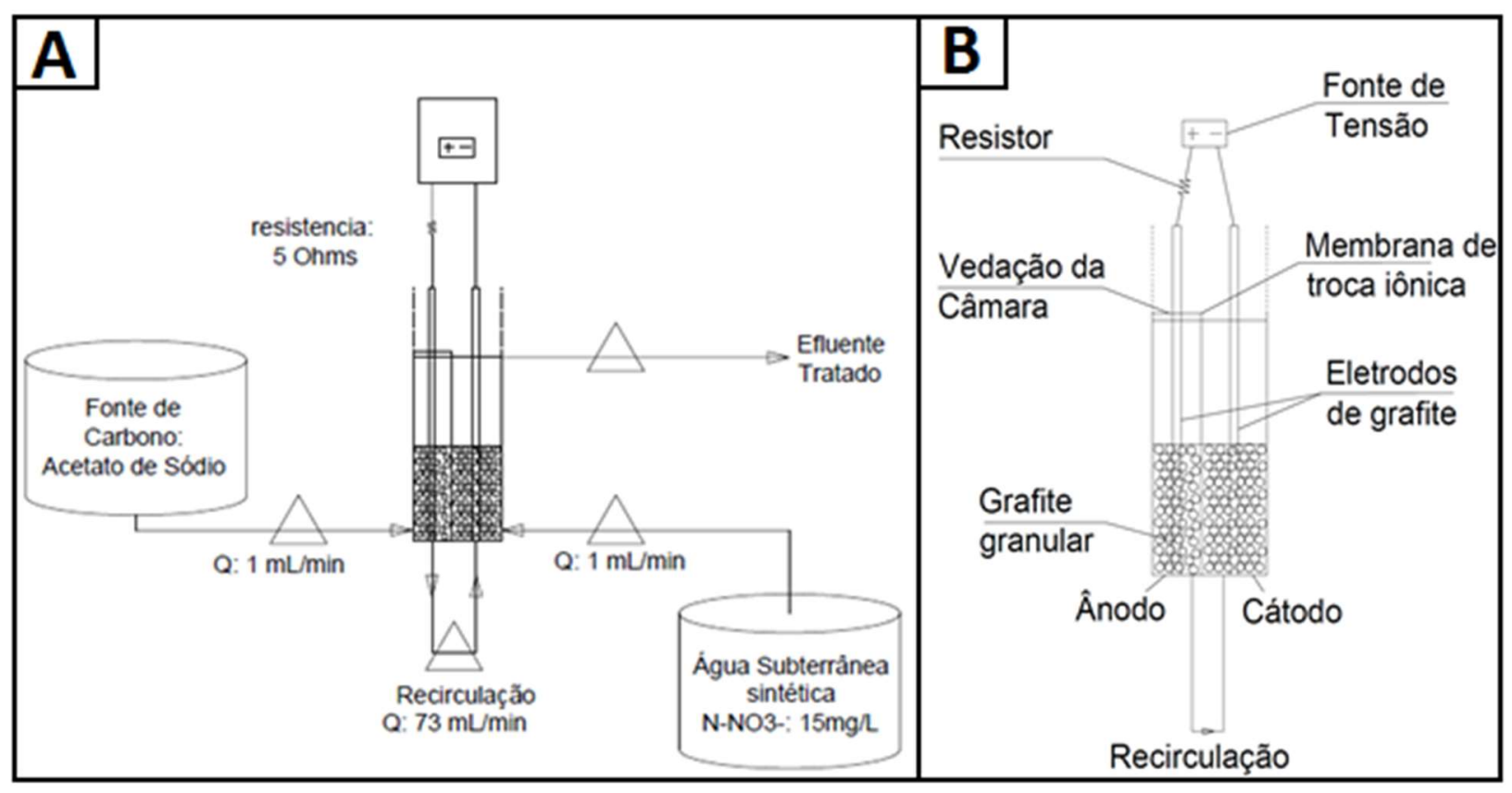

Figura 14 - (A) Representação esquemática do sistema bioeletroquímico; (B) Detalhes dos componentes.

A Figura 15-A apresenta o experimento instalado: o reator MFC com os compartimentos anódico e catódico encontram-se ao centro; duas bombonas brancas armazenaram cada qual a fonte carbono e a água subterrânea sintética; mangueiras de silicone com diâmetro interno de $3 \mathrm{~mm}$ conduziram as soluções das bombonas para os compartimentos; cinco bombas peristálticas foram responsáveis pela circulação dos fluidos, quatro delas conectadas a um controlador PWM para regulagem da vazão. A primeira bomba, no quadro da esquerda para direita, alimentou o cátodo, a segunda o ânodo, a terceira e a quarta bomba realizaram a recirculação entre os compartimentos anódico e catódico, e a quinta bomba (modelo FH series, da Thermo Scientifc) extraiu o efluente tratado de forma contínua. Por fim, à direita, está a fonte reguladora de tensão, utilizada nos testes que envolveram aplicação de energia. A Figura 15-B e C mostram os compartimentos anódico e catódico separados pela membrana de troca iônica; fios ligados entre a resistência de $5 \Omega$ e as placas de grafite fecham o circuito. 


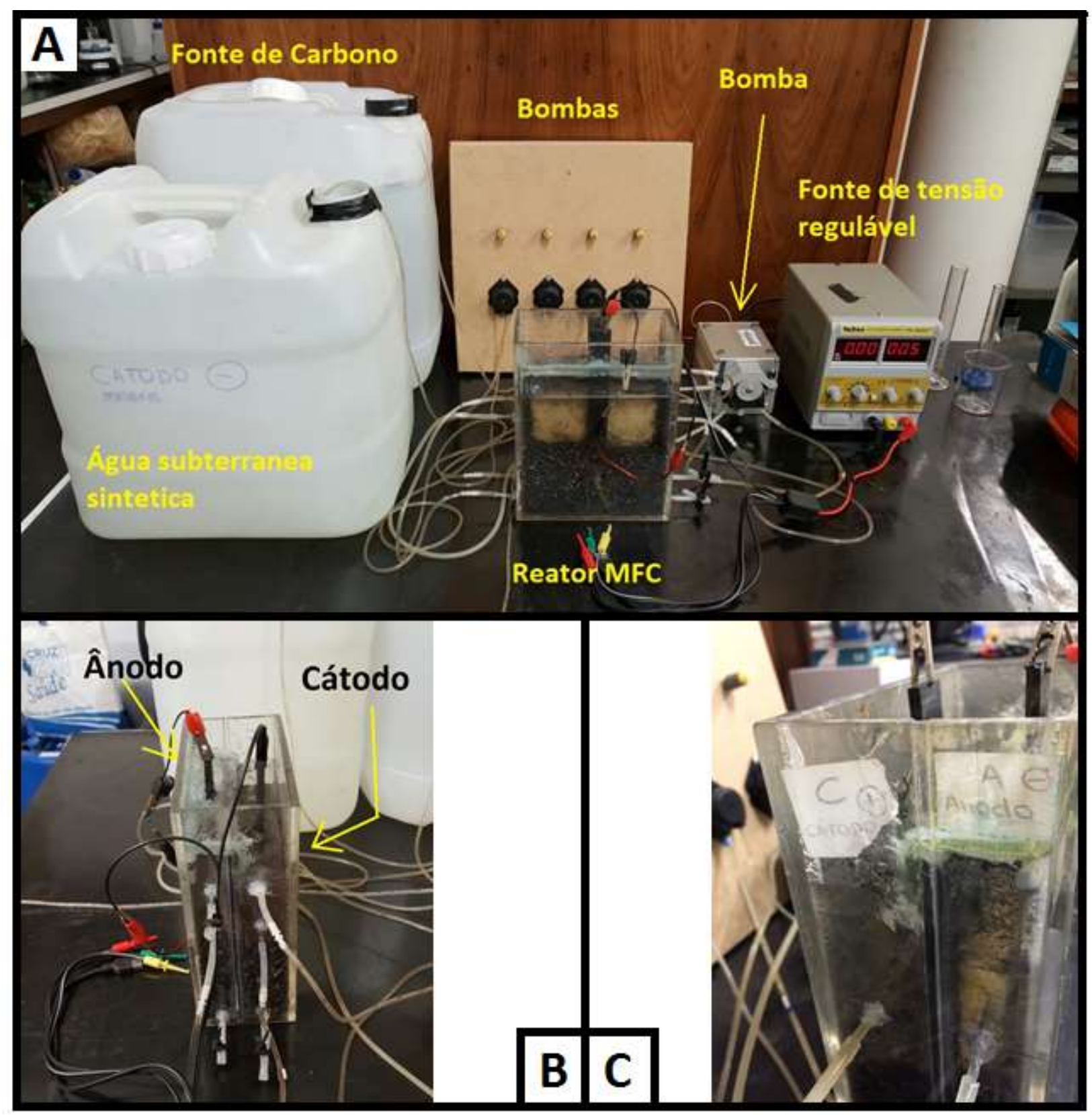

A - Sistema Bioeletroquímico estudado

B - Compartimentos anódico e catódico - vista lateral esquerda

C - Compartimentos anódico e catódico - vista lateral direita

Figura 15 - Sistema bioeletroquímico.

Para conseguir atingir a vazão de alimentação de $1 \mathrm{~mL} / \mathrm{min}$ no ânodo e cátodo, necessitouse de um temporizador ajustado para acionar as bombas a cada 30 segundos. Somente a $5^{\mathrm{a}}$ bomba do sistema trabalhou sem o temporizador.

A membrana Ultrex CMI-7000, cujas especificações encontram-se no ANEXO I Especificações Técnicas da Membrana de Troca iônica foi previamente imergida, conforme orientações, em uma solução de $5 \%$ de cloreto de sódio $(\mathrm{NaCl})$ por $12 \mathrm{~h}$, de forma a promover sua hidratação e expansão.

Preparou-se uma composição de água subterrânea sintética (Tabela 9) baseada em Puig et al. (2012), com o emprego do sal de nitrato de sódio como fonte de nitrogênio. Visto que 
a concentração máxima média registrada pelo monitoramento da CETESB (item 3.1.1) foi de 14,26 mg N-NO ${ }_{3}^{-} / \mathrm{L}$, optou-se por dosar a concentração da solução de injeção em 15 mg N-NO${ }_{3} / \mathrm{L}$, mantida constante durante todo o experimento.

Tabela 9 - Composição da solução sintética injetada no cátodo.

\begin{tabular}{|c|c|c|c|}
\hline \multicolumn{4}{|c|}{ Água subterrânea sintética - $15 \mathrm{~N}-\mathrm{NO}_{3}^{-}(\mathrm{mg} / \mathrm{L})$} \\
\hline & Composto & Nome & Concentração (mg/L) \\
\hline 1 & $\mathrm{NaHCO}_{3}$ & Bicarbonato de sódio & 161,95 \\
\hline 2 & $\mathrm{NaNO}_{3}$ & Nitrato de sódio & 66,37 \\
\hline 3 & $\mathrm{NaH}_{2} \mathrm{PO}_{4} \cdot 2 \mathrm{H}_{2} \mathrm{O}$ & Fosfato dissódico & 361,73 \\
\hline 4 & $\mathrm{KH}_{2} \mathrm{PO}_{4} \cdot 2 \mathrm{H}_{2} \mathrm{O}$ & Fosfato monobásico & 159,29 \\
\hline 5 & $\mathrm{CaCl}_{2} \cdot 2 \mathrm{H}_{2} \mathrm{O}$ & Cloreto de cálcio & 1,86 \\
\hline 6 & $\mathrm{MgSO}_{4} \cdot 7 \mathrm{H}_{2} \mathrm{O}$ & Sulfato de magnésio & 11,95 \\
\hline 7 & $\mathrm{KCl}$ & Cloreto de potássio & 1,73 \\
\hline & \multicolumn{2}{|c|}{ Solução microelementos* } & 0,06 \\
\hline
\end{tabular}

*Solução de microelementos composta por 1g/L EDTA, 1g/L FeSO ${ }_{4} \cdot 7 \mathrm{H}_{2} \mathrm{O}, 70 \mathrm{mg} / \mathrm{L} \mathrm{ZnCl} 2,100 \mathrm{mg} / \mathrm{L} \mathrm{MnCl} 2 \cdot 4 \mathrm{H}_{2} \mathrm{O}, 6$ $\mathrm{mg} / \mathrm{L} \mathrm{H}_{3} \mathrm{BO}_{3}, 130 \mathrm{mg} / \mathrm{L} \mathrm{CaCl} 2 \cdot 6 \mathrm{H}_{2} \mathrm{O}, 2 \mathrm{mg} / \mathrm{L} \mathrm{CuCl} 2 \cdot 2 \mathrm{H}_{2} \mathrm{O}, 24 \mathrm{mg} / \mathrm{L} \mathrm{NiCl} \cdot 6 \mathrm{H}_{2} \mathrm{O}, 36 \mathrm{mg} / \mathrm{L} \mathrm{Na} 2 \mathrm{Mo}_{4} \cdot 2 \mathrm{H}_{2} \mathrm{O}, 238 \mathrm{mg} / \mathrm{L}$ $\mathrm{CoCl}_{2} \cdot 6 \mathrm{H}_{2} \mathrm{O}$.

A composição da fonte de carbono (Tabela 10) também baseada em Puig et al. (2012), foi adaptada para a concentração de $15 \mathrm{mg} \mathrm{N}-\mathrm{NO}_{3}-\mathrm{L}$.

Tabela 10 - Composição da solução de fonte de carbono injetada do ânodo.

\begin{tabular}{|ll|l|l|}
\hline \multicolumn{2}{|l|}{ Fonte de Carbono - Acetato de sódio } & \\
\hline \multicolumn{2}{|l|}{ Composto } & Nome & Concentração $(\mathrm{mg} / \mathrm{L})$ \\
\hline 1 & $\mathrm{CH}_{3} \mathrm{COONa}$ & Acetato de sódio & 298,67 \\
\hline 2 & $\mathrm{NaHCO}$ & 101,22 \\
\hline 3 & $\mathrm{NH}_{4} \mathrm{Cl}$ & Bicarbonato de sódio & 6,34 \\
\hline 4 & $\mathrm{NaH}_{2} \mathrm{PO}_{4} \cdot 2 \mathrm{H}_{2} \mathrm{O}$ & Cloreto de amônio & 226,13 \\
\hline 5 & $\mathrm{KH}_{2} \mathrm{PO}_{4} \cdot 2 \mathrm{H}_{2} \mathrm{O}$ & Fosfato dissódico & 99,56 \\
\hline 6 & $\mathrm{CaCl}_{2} \cdot 2 \mathrm{H}_{2} \mathrm{O}$ & Cloreto de cálcio & 1,16 \\
\hline 7 & $\mathrm{MgSO}_{4} \cdot 7 \mathrm{H}_{2} \mathrm{O}$ & Sulfato de magnésio & 7,47 \\
\hline 8 & $\mathrm{KCl}$ & Cloreto de potássio & 0,06 \\
\hline 9 & $\mathrm{Solução} \mathrm{microelementos}$ & 0,06 \\
\hline
\end{tabular}

*Solução de microelementos composta por 1g/L EDTA, 1 $/ \mathrm{L} \mathrm{FeSO} \cdot 7 \mathrm{H}_{2} \mathrm{O}, 70 \mathrm{mg} / \mathrm{L} \mathrm{ZnCl} 2,100 \mathrm{mg} / \mathrm{L} \mathrm{MnCl} \cdot 4 \mathrm{H}_{2} \mathrm{O}, 6$ $\mathrm{mg} / \mathrm{L} \mathrm{H}_{3} \mathrm{BO}_{3}, 130 \mathrm{mg} / \mathrm{L} \mathrm{CaCl} 2 \cdot 6 \mathrm{H}_{2} \mathrm{O}, 2 \mathrm{mg} / \mathrm{L} \mathrm{CuCl} \cdot 2 \mathrm{H}_{2} \mathrm{O}, 24 \mathrm{mg} / \mathrm{L} \mathrm{NiCl} \cdot 6 \mathrm{H}_{2} \mathrm{O}, 36 \mathrm{mg} / \mathrm{L} \mathrm{Na} 2 \mathrm{Mo}_{4} \cdot 2 \mathrm{H}_{2} \mathrm{O}, 238 \mathrm{mg} / \mathrm{L}$ $\mathrm{CoCl}_{2} \cdot 6 \mathrm{H}_{2} \mathrm{O}$.

A preparação da água subterrânea sintética para o cátodo e a fonte de carbono para o ânodo seguiu as diretrizes metodológicas descritas no Standard Methods for the Examination of Water and Wastewater (APHA, 2005).

Por fim, foram monitorados parâmetros de controle (Tabela 11), observações visuais sobre o sistema, como funcionamento das bombas e volume armazenado de soluções que alimentam o sistema, também foram consideradas. 
Tabela 11 - Parâmetros de controle para o sistema bioeletroquímico.

\begin{tabular}{|l|l|}
\hline Parâmetros de controle & Valor de referência \\
\hline Nível de efluente tratado & Variável ${ }^{*}$ \\
\hline Condições das bombas & Operante \\
\hline Tubulações e conexões & Desobstruídos \\
\hline $\mathrm{pH}$ & $7-9$ \\
\hline Temperatura $\left({ }^{\circ} \mathrm{C}\right)$ & $20-32$ \\
\hline
\end{tabular}

* nível deve estar condizente com o volume de tratamento previsto, de acordo com TDH

\subsection{Descrição dos ensaios realizados}

O experimento consistiu de 8 testes (Tabela 12). O Teste 1 correspondeu à fase de aclimatação, na qual o sistema operou por 45 dias em circuito aberto (CA), ou seja, as câmaras anódicas e catódicas não estiveram conectadas por um resistor. O Teste 2 deu início à fase experimental e continuou em circuito aberto por mais 80 dias após a aclimatação. A partir do Teste 3, as câmaras foram conectadas pelo resistor operando então em modo MFC (circuito fechado, porém sem potencial aplicado externamente). O Teste 3 foi monitorado por 115 dias. Nos Testes 4, 5 e 6, as vazões de alimentação foram aumentadas gradativamente, partindo de 2,88 L/dia até 11,52 L/dia, com o objetivo de se analisar os limites do sistema, e a partir do Teste 7 iniciaram-se os ensaios em modo MEC (com potencial aplicado externamente), com aplicação de $0,5 \mathrm{~V}$ no Teste 7 e 1,0V no Teste 8 . Os Testes 4 a 8 foram executados com 8 dias de duração cada qual. Todas as análises realizadas a partir do Teste 4 foram triplicadas para validação dos resultados.

Tabela 12 - Resumo das condições da investigação experimental.

\begin{tabular}{|c|c|c|c|c|c|c|c|}
\hline Teste & $\begin{array}{l}\text { Fonte de } \\
\text { Carbono } \\
\mathrm{CH}_{3} \mathrm{COONa} \\
\text { (g/L.dia) }\end{array}$ & $\begin{array}{l}\text { Nitrato } \\
\mathrm{N}-\mathrm{NO}_{3}^{-} \\
\text {(g/L.dia) }\end{array}$ & $\begin{array}{l}\text { Vazão de } \\
\text { alimentação } \\
\text { (cátodo+ânodo)* }\end{array}$ & $\begin{array}{l}\text { TDH } \\
\text { (h) }\end{array}$ & $\begin{array}{l}\text { Modo de } \\
\text { operação }\end{array}$ & $\begin{array}{l}\text { Potencial } \\
\text { externo }\end{array}$ & $\begin{array}{l}\text { Tempo } \\
\text { de } \\
\text { operação }\end{array}$ \\
\hline \#1 & 0,8602 & 0,0432 & 2,88 L/dia & 7,5 & $\begin{array}{l}\text { Aclimatação } \\
\text { CA }\end{array}$ & - & 45 dias \\
\hline \#2 & 0,8602 & 0,0432 & 2,88 L/dia & 7,5 & $\mathrm{CA}$ & - & 80 dias \\
\hline \#3 & 0,8602 & 0,0432 & 2,88 L/dia & 7,5 & MFC & - & 115 dias \\
\hline \#4 & 0,8602 & 0,0432 & $2,88 \mathrm{~L} / \mathrm{dia}$ & 7,5 & MFC & - & 8 dias \\
\hline \#5 & 1,7204 & 0,0864 & 5,76 L/dia & 3,8 & MFC & - & 8 dias \\
\hline \#6 & 3,4407 & 0,1728 & 11,52 L/dia & 1,9 & MFC & - & 8 dias \\
\hline$\# 7$ & 3,4407 & 0,1728 & 11,52 L/dia & 1,9 & MEC & $0,5 \mathrm{~V}$ & 8 dias \\
\hline$\# 8$ & 3,4407 & 0,1728 & 11,52 L/dia & 1,9 & MEC & $1,0 \mathrm{~V}$ & 8 dias \\
\hline
\end{tabular}

* Corresponde a soma das vazões de ambos compartimentos alimentados equitativamente

Nos ensaios com circuito fechado e aplicação externa de corrente elétrica, foi utilizada uma resistência de $5 \Omega$ e aplicada uma tensão de $0,5 \mathrm{~V}$, e $1,0 \mathrm{~V}$ através da fonte regulável. Aplicando a Lei de Ohm, o sistema operou com correntes de 100 mA e 200 mA. 


\subsection{Metodologia de avaliação do experimento}

Diante das variações de TDH, do modo de operação e da aplicação de corrente nos testes, o experimento foi avaliado por meio da eficiência de remoção de nitrato, da eficiência de Coulomb que avalia se o processo bioeletroquímico de fato está removendo nitrato, a estimativa de geração de $\mathrm{N}_{2} \mathrm{O}$, da relação alcalinidade versus desnitrificação e da estimativa da densidade de corrente para análise da produção de corrente no processo. Tais metodologias foram selecionadas de forma a possibilitar a comparação com os estudos existentes.

\section{Eficiência de remoção do nitrato}

A eficiência da remoção de nitrato foi calculada através da equação 8, no item 3.3.4.10.

\section{Eficiência de Coulomb}

Observou-se no item 3.3.4.10 que as metodologias de cálculo apresentadas nos estudos existentes assemelham-se quanto ao processo de avaliação (fluxo contínuo e batelada). As variáveis envolvidas são praticamente as mesmas, e dessa forma, optou-se por utilizar a equação proposta por Virdis et al. (2008) para cálculo da eficiência de Coulomb (Equação 11), as variáveis analisadas são: corrente produzida $(A)$, diferença de concentração de $\mathrm{N}^{-\mathrm{NO}_{3}}{ }^{-}$inicial e final ( $\left.\mathrm{mg} \mathrm{N}^{-\mathrm{NO}_{3}}{ }^{-} / \mathrm{L}\right)$, e vazão de entrada (L/s).

\section{Estimativa de geração de $\mathrm{N}_{2} \underline{\mathrm{O}}$}

Infelizmente não foi possível a realização das medições analíticas de $\mathrm{N}_{2} \mathrm{O}$ no processo de desnitrificação do experimento. Dessa forma, os valores de $\mathrm{N}_{2} \mathrm{O}$ foram obtidos de forma indireta através da correlação da eficiência de Coulomb obtida no experimento com os valores de Virdis et al. (2009) (item 3.3.4.10).

\section{$\underline{\text { Relação Alcalinidade x Desnitrificação }}$}

A alcalinidade tende a aumentar à medida que ocorre o processo de desnitrificação (item 3.2.1). Avaliaram-se assim as concentrações de nitrato e os valores de alcalinidade no efluente, de modo a verificar se existia correlação.

\section{$\underline{\text { Densidade de corrente }}$}

O cálculo para densidade de corrente foi baseado na Equação 16 de densidade de potência (item 3.3.4.10).No entanto o volume considerado representou o volume do material granular do compartimento anódico de $424 \mathrm{~cm}^{3}$. 


\subsection{Análises laboratoriais}

Foram realizadas regularmente análises laboratoriais alinhadas aos parâmetros de controle e aos objetivos da pesquisa (Tabela 13). Nos Testes 1 a 3 as análises foram realizadas de 2 a 5 dias por semana; a partir do Teste 4 as coletas e aferições tiveram periodicidade horária com 8 a 10 coletas no dia e triplicatas com intervalo de 24 a 48 h e as medições de alcalinidade e condutividade foram iniciadas também nesta fase. A coleta e análise dos parâmetros seguiram as metodologias descritas no Standard Methods for Examination of Water and Wastewater (APHA / AWWA / WEF, 2005).

Tabela 13 - Análises laboratoriais realizadas.

\begin{tabular}{|l|l|l|l|}
\hline Parâmetros & Objetivo & $\begin{array}{l}\text { Período de } \\
\text { monitoramento }\end{array}$ & $\begin{array}{l}\text { Referência Standard } \\
\text { Methods }\end{array}$ \\
\hline $\mathrm{pH}$ & Controle do processo & Testes 1 a 8 & Método - 4500H+-B \\
\hline Temperatura & Controle do processo & Testes 1 a 8 & Método - 2550-B \\
\hline N-Nitrato & $\begin{array}{l}\text { Eficiência de remoção, Eficiência de } \\
\text { Coulomb }\end{array}$ & Testes 1 a 8 & Método - 4110-B \\
\hline N-Nitrito & $\begin{array}{l}\text { Eficiência de remoção, Eficiência de } \\
\text { Coulomb }\end{array}$ & Testes 1 a 8 & Método - 4110-B \\
\hline Cloreto & Avaliação do tratamento & Testes 1 a 8 & Método - 4110-B \\
\hline F-Fosfato & Avaliação do tratamento & Testes 1 a 8 & Método - 4110-B \\
\hline Sulfato & Avaliação do tratamento & Testes 1 a 8 & Método - 4110-B \\
\hline $\begin{array}{l}\text { Condutividade } \\
\text { elétrica }\end{array}$ & Relação no processo bioeletroquímico & Testes 4 a 8 & Método - 2510 \\
\hline Alcalinidade & Relação Alcalinidade x desnitrificação & Testes 4 a 8 & Método - 2320-B \\
\hline
\end{tabular}

As análises de $\mathrm{N}^{-\mathrm{NO}_{3}}{ }^{-}$e $\mathrm{N}-\mathrm{NO}_{2}{ }^{-}$foram realizadas em um cromatógrafo de íons (Dionex100, coluna ASCR2_mm e CSCR2_mm). Utilizaram-se brancos de laboratório e padrões dos parâmetros de interesse. As concentrações de $\mathrm{N}_{2} \mathrm{O}$ e $\mathrm{N}_{2}$ foram estimadas de forma indireta, conforme descrito no item 4.3. A produção de óxido nítrico (NO) foi considerada desprezível. A corrente elétrica gerada no sistema foi monitorada através de um multímetro.

\subsection{Análise estatística dos resultados}

Os resultados obtidos foram analisados estatisticamente e graficamente através de séries temporais e diagramas boxplot.

\section{- Séries Temporais}

As séries temporais foram analisadas utilizando média móvel de 4 termos, de forma a suavizar a linha de tendência. As médias móveis são uma forma alternativa de obtenção da tendência ou nível de uma série temporal. Calcula-se a média aritmética dos primeiros $n$ períodos da série, colocando-se o resultado no período exatamente no centro deles. Progressivamente, 
acrescenta-se um período seguinte e despreza-se o primeiro valor considerado na média imediatamente anterior, e calculando novas médias, que vão se movendo até o fim da série. $O$ número de períodos ( $n$ ) é chamado de ordem da série (REIS, 2017).

\section{- Diagrama Boxplot}

O diagrama boxplot analisa os dados em percentis e apresenta os dados em uma caixa construída paralelamente ao eixo da escala dos dados. Essa caixa apresenta variações de valores de mínimos e máximos além do primeiro quartil até o terceiro quartil de um determinado dado de amostragem, o valor central é dado pela mediana e a dispersão pela amplitude interquartis (FARIAS, 2009). Os dados amostrados que estiverem acima ou abaixo desses limites são identificadas no diagrama e consideradas valores atípicos 


\section{APRESENTAÇÃO E DISCUSSÃO DOS RESULTADOS}

Neste item são apresentados os resultados obtidos experimentalmente durante o período de análise do sistema, com duração de 280 dias corridos (21/09/16 a 27/06/17). O ANEXO II Resultados das análises laboratoriais apresenta os dados brutos coletados durante a pesquisa.

\subsection{Resultados do controle do processo}

Embora temperatura e $\mathrm{pH}$ tenham sido parâmetros previamente selecionados para realização do controle do processo, ao longo de todo o experimento não foi necessária intervenção nestes.

As temperaturas ficaram em média a $22,37 \pm 1,11^{\circ} \mathrm{C}$ (Figura 16). Não houve grande amplitude, a série temporal (Figura 17), mostra que a variação se deu basicamente pela sazonalidade do período de coleta dados, tais valores encontram-se dentro da faixa em que ocorre a desnitrificação.

\begin{tabular}{|l|c|}
\hline \multicolumn{2}{|c|}{ Tem peratura $\left({ }^{\circ} \mathbf{C}\right)$} \\
\hline Média & 22,37 \\
\hline Máximo & 23,91 \\
\hline Mínimo & 20,73 \\
\hline Desvio padrão & 1,11 \\
\hline Coef. Variação (\%) & 0,05 \\
\hline
\end{tabular}

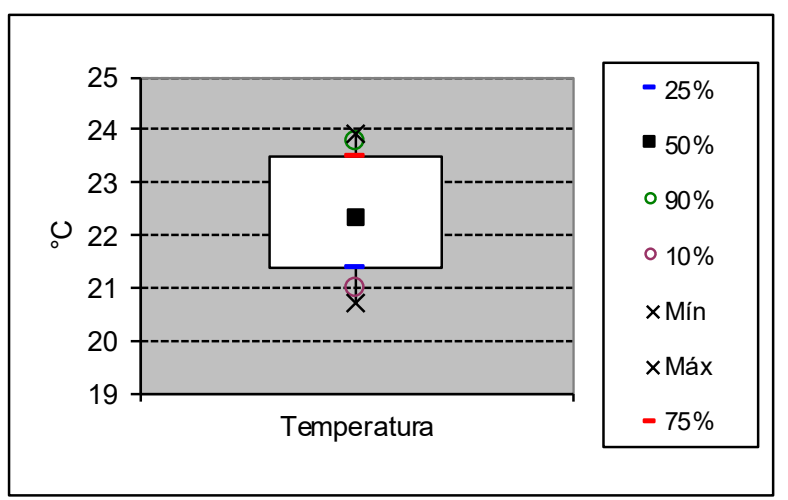

Figura 16 -Diagrama Boxplot para temperatura.

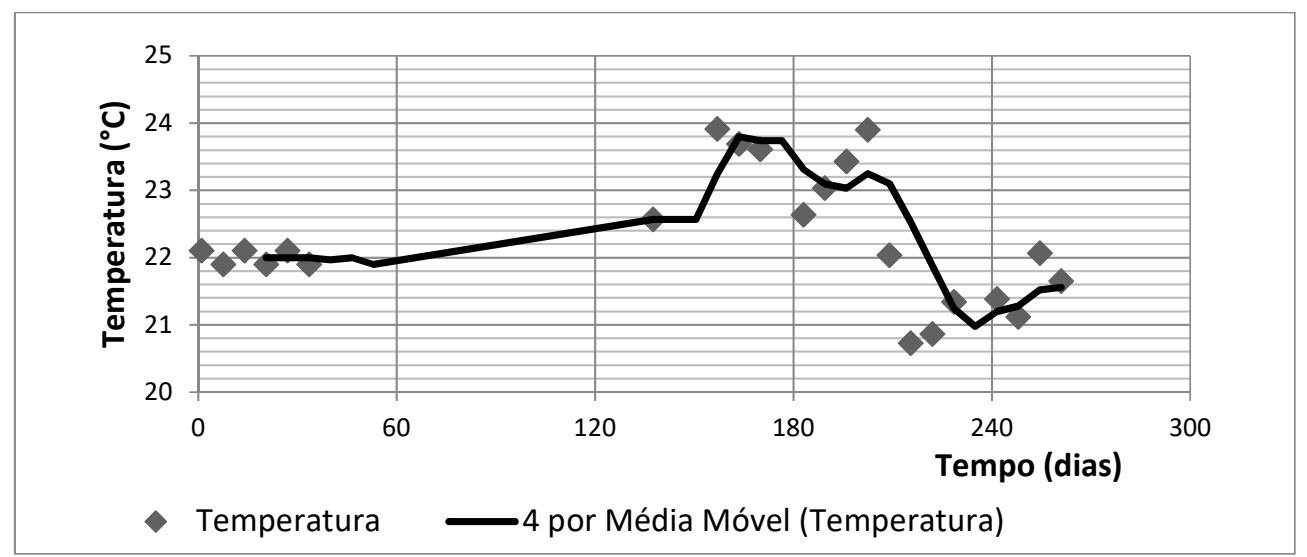

Figura 17 - Série temporal para temperatura.

Assim como a temperatura, os dados coletados sobre o $\mathrm{pH}$ são apresentados em série temporal com médias móveis de 4 termos (Figura 19) e análises estatísticas (Figura 18). O pH 
teve pequena variação com média de 7,35 $\pm 0,13$. A faixa de valores obtida é favorável para que ocorra a desnitrificação.

\begin{tabular}{|l|c|}
\hline \multicolumn{2}{|c|}{ pH } \\
\hline Média & 7,35 \\
\hline Máximo & 7,69 \\
\hline Mínimo & 7,14 \\
\hline Desvio padrão & 0,13 \\
\hline Coef. Variação (\%) & 0,02 \\
\hline
\end{tabular}

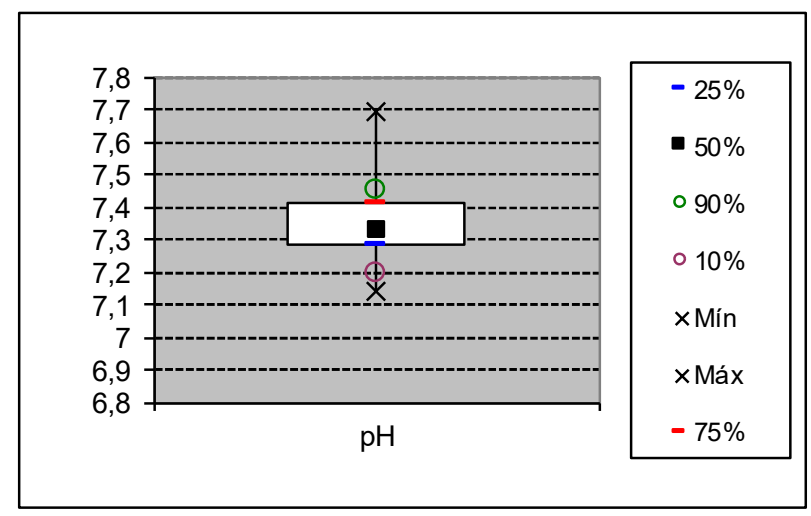

Figura 18 - Variação do pH, considerando todos os testes e Diagrama Boxplot - pH.

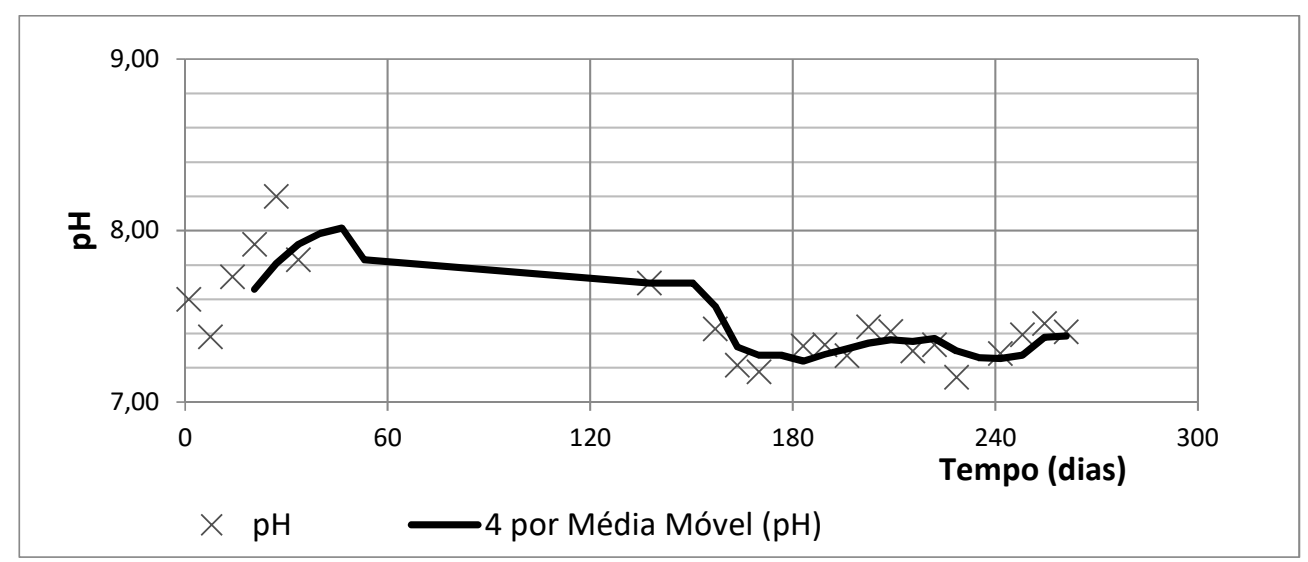

Figura 19 - Série temporal com médias móveis de 4 termos - pH.

\subsection{Eficiência de remoção de nitrato}

Nos gráficos sobre o nitrato, a solução de água subterrânea sintética é chamada como afluente, e a solução tratada pelo processo bioeletroquímico como efluente.

A concentração de entrada da água subterrânea sintética ficou em 15,56 $\pm 2,88 \mathrm{mg} \mathrm{N}-\mathrm{NO}_{3}{ }^{-}$

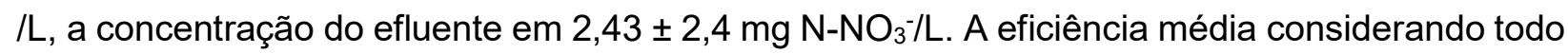
o período do experimento foi de $80,84 \pm 16,73 \%$. 


\begin{tabular}{|l|c|c|}
\hline \multicolumn{3}{|c|}{ Nitrato (m g/L) } \\
\hline & Afluente & Efluente \\
\hline Média & 15,56 & 2,43 \\
\hline Máximo & 24,68 & 9,00 \\
\hline Mínimo & 12,70 & 0,00 \\
\hline Desvio padrão & 2,88 & 2,40 \\
\hline Coef. Var & 0,19 & 0,99 \\
\hline
\end{tabular}

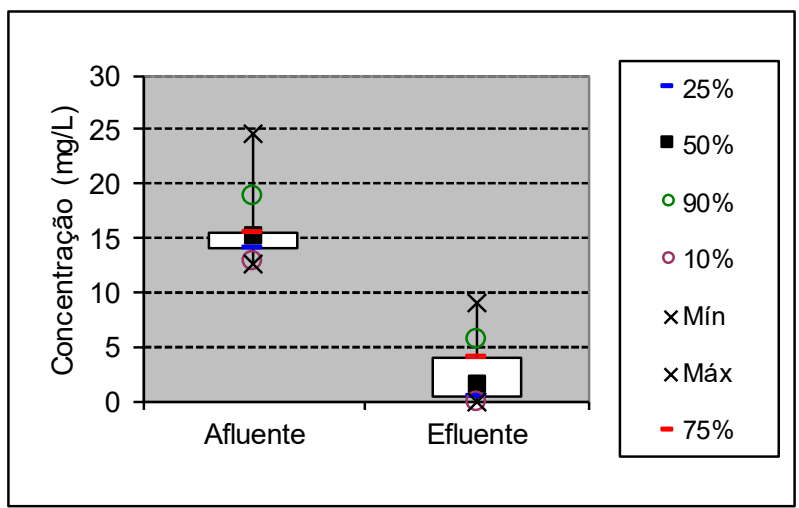

Figura 20 - Variação do $\mathrm{N}-\mathrm{NO}_{3}{ }^{-}$, considerando todos os testes e Diagrama Boxplot

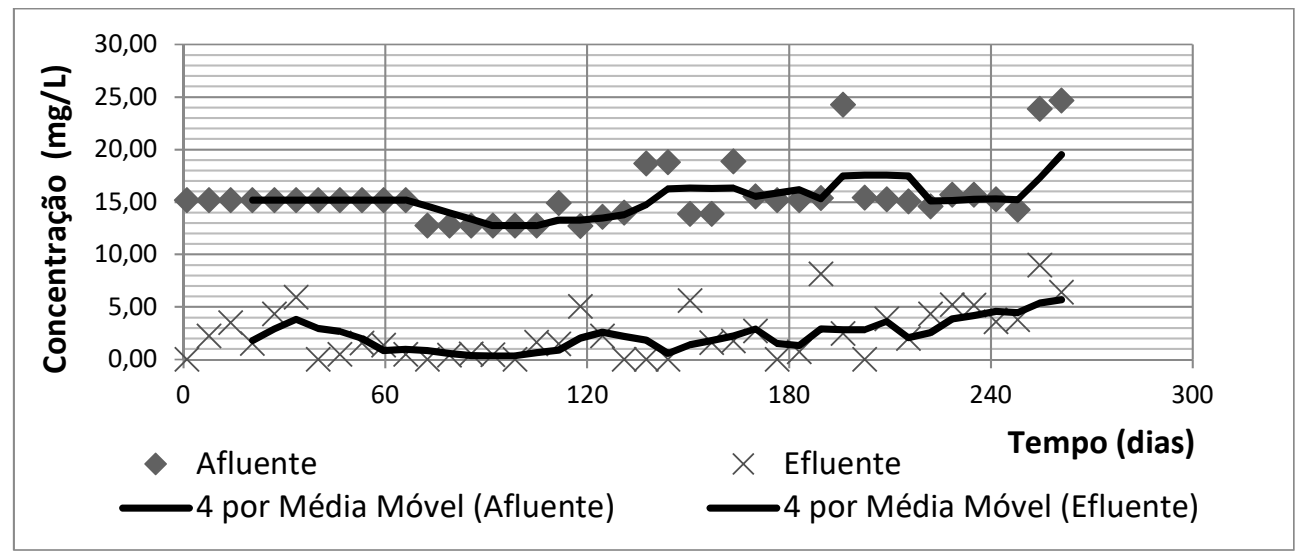

Figura 21 - Série temporal com médias móveis de 4 termos $-\mathrm{N}-\mathrm{NO}_{3}{ }^{-}$

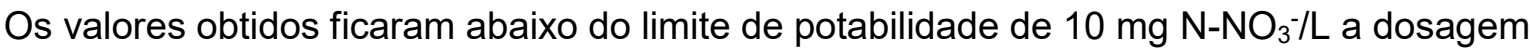
de concentração de entrada não interferiu na remoção do contaminante, indicando que o nitrato não é um limitante do processo.

A partir do Teste 4 foram realizadas medições horárias no sistema, a fim de se observar mais atentamente o processo de desnitrificação no sistema bioeletroquímico (Figura 22 e Figura 23). Também analisou-se estatisticamente a eficiência de cada teste (Tabela 14 e Figura 24), e a remoção de nitrato em kg/m³.dia (Tabela 15 e Figura 25). 

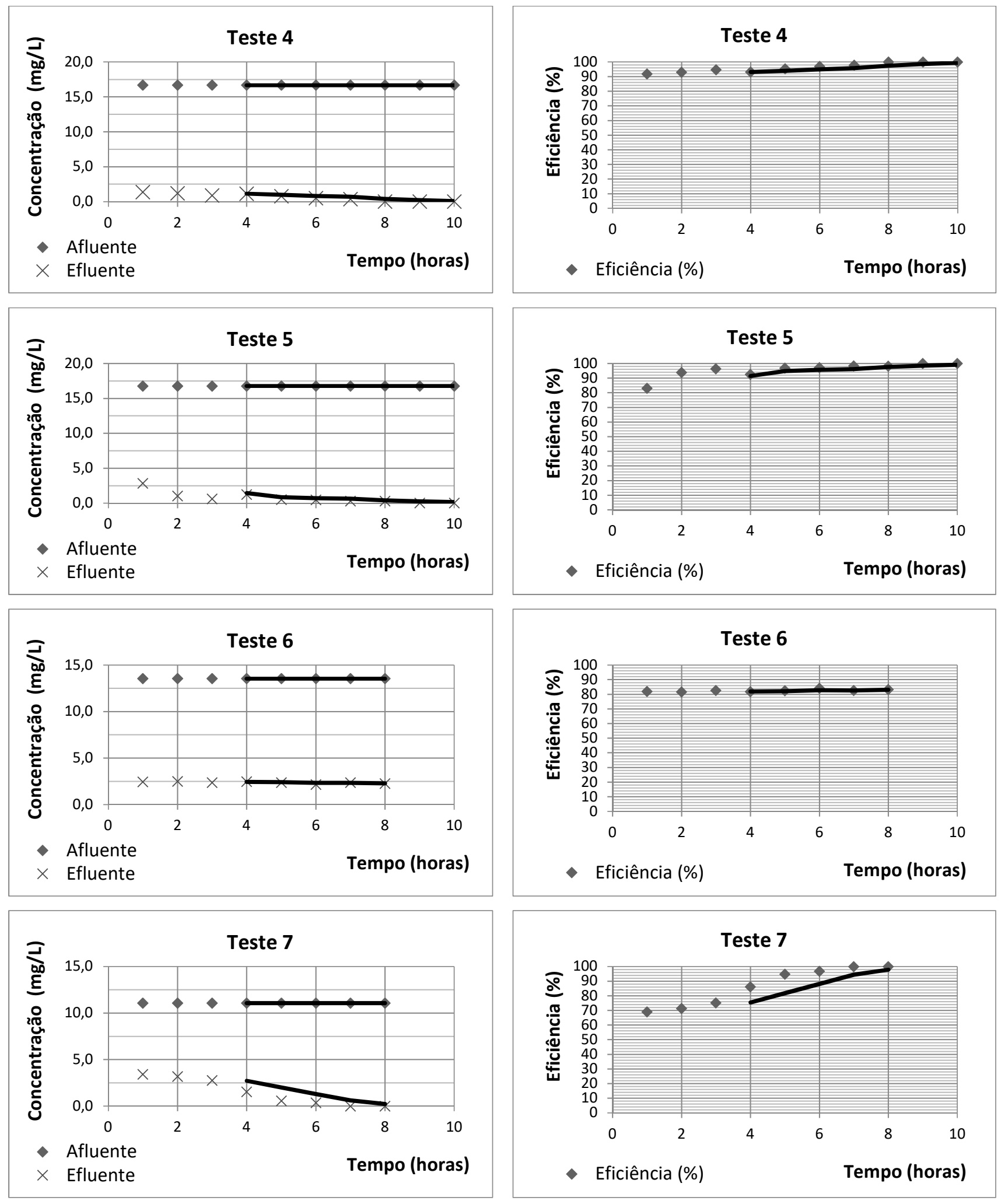

Figura 22 - Resultados das análises horárias - $\mathrm{N}-\mathrm{NO}_{3}{ }^{-}$ 

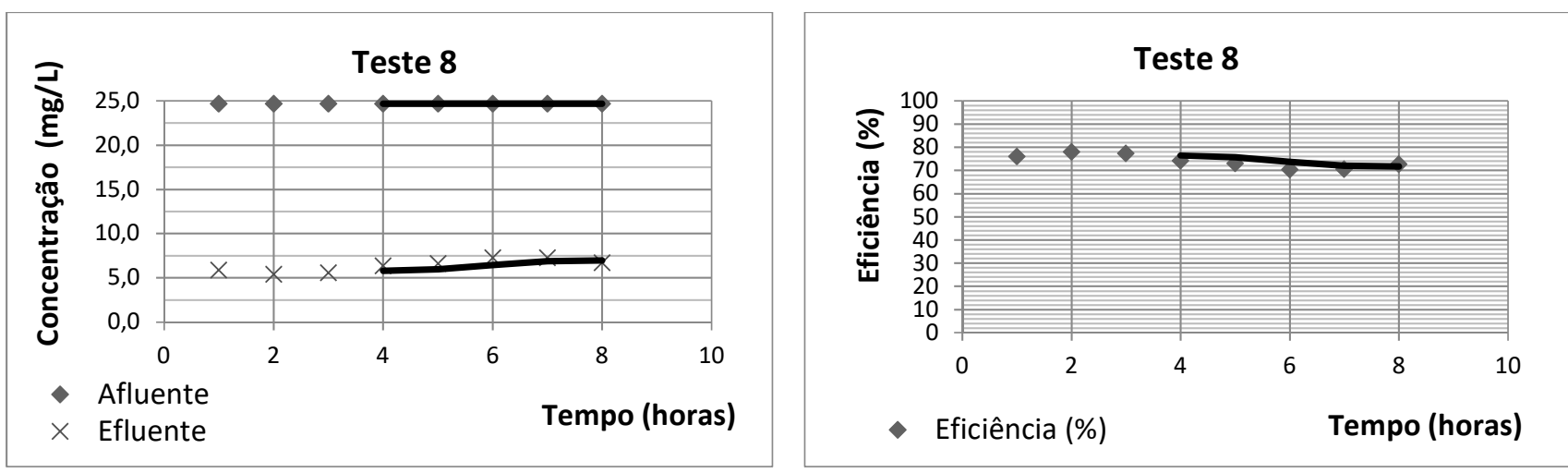

Figura 23 - Resultados das análises horárias - $\mathrm{N}-\mathrm{NO}_{3}{ }^{-}$

Tabela 14 - Estatística da eficiência de remoção de $\mathrm{N}-\mathrm{NO}_{3}{ }^{-}$(\%) para cada teste.

\begin{tabular}{|l|l|l|l|l|l|l|l|l|l|}
\hline & Teste 1 & Teste 2 & Teste 3 & Teste 4 & Teste 5 & Teste 6 & Teste 7 & Teste 8 & TOTAL \\
\hline Média & 85,68 & 88,19 & 83,41 & 95,66 & 90,66 & 67,90 & 76,67 & 70,28 & 80,84 \\
\hline Máximo & 100,00 & 100,00 & 83,80 & 100,00 & 100,00 & 100,00 & 100,00 & 96,37 & 100,00 \\
\hline Mínimo & 56,15 & 60,12 & 83,02 & 26,28 & 59,46 & 40,35 & 63,21 & 57,77 & 26,28 \\
\hline Desvio padrão & 13,58 & 14,28 & 0,56 & 17,88 & 11,08 & 22,09 & 11,27 & 9,59 & 16,73 \\
\hline Coef. Variação & 0,16 & 0,16 & 0,01 & 0,19 & 0,12 & 0,33 & 0,15 & 0,14 & 0,21 \\
\hline
\end{tabular}

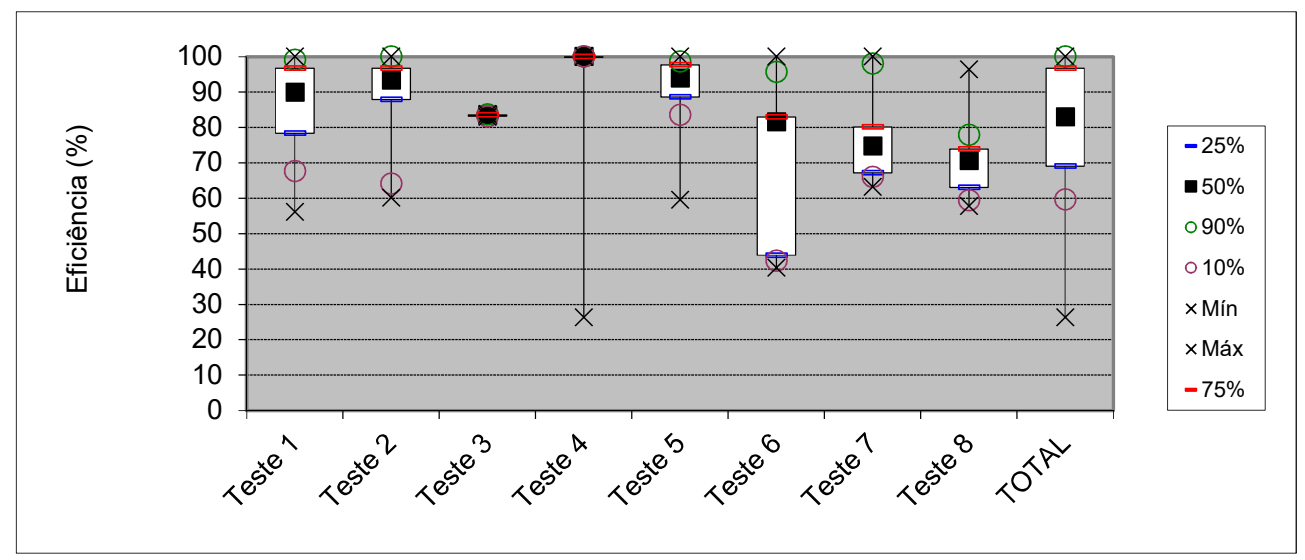

Figura 24 - Diagrama Boxplot - Eficiência de remoção $\mathrm{N}-\mathrm{NO}_{3}^{-}$(\%)

Observa-se que os diversos ensaios obtiveram altos valores de eficiência. Desde o Teste 1 (fase em que ocorreu a aclimatação), o sistema já apresentava capacidade de remoção. Isto pode ser atribuído ao inóculo utilizado para iniciar o processo, que foi retirado de um lodo biológico onde já ocorria desnitrificação. Além disso, não houve necessidade de nova adição de microrganismos durante todo o experimento: a colônia de microrganismos foi monitorada apenas de forma visual (Figura 32), fazendo-se notar seu crescimento durante todo o processo.

O Teste 4 apontado como o de melhor eficiência de remoção $(95,66 \pm 17,88$ \%) operou em modo MFC (sem aplicação de energia externa) e um TDH de 7,5 h. A partir desse ponto optouse por forçar mais o sistema no Teste 5 dobrando a taxa de aplicação (5,76 L/dia) e com isso diminuindo o TDH para $3,8 \mathrm{~h}$, o sistema respondeu de maneira satisfatória chegando a valores médios de 90,66 $\pm 11,08 \%$ de eficiência. Com isso, no Teste 6 dobrou-se novamente a taxa de 
aplicação (11,52 L/dia) e TDH de 1,9 h. Nesta fase a eficiência caiu para valores médios de $67,9 \% \pm 22,09 \%$, e nos testes subsequentes foi então aplicada a corrente externa no sistema.

Notou-se um aumento gradativo na eficiência de remoção de nitrato do Teste 7 (Figura 22). Entretanto, no Teste 8, apesar da maior aplicação de corrente (200 mA e 1,0V), a eficiência não respondeu de forma proporcional. Tong e He (2013) em seus testes de variação de tensão também registraram que a eficiência não aumentava proporcionalmente com aplicação de tensão, o que corrobora com os resultados obtidos.

Os valores de remoção de nitrato em $\mathrm{kg} / \mathrm{m}^{3}$.dia aumentam devido ao aumento do TDH, apesar da maior eficiência apontada no Teste 4, o Teste 8 remove mais nitrato nesta unidade de medida.

Tabela 15 - Remoção de $\mathrm{N}-\mathrm{NO}_{3}{ }^{-}$(kg/m³. dia)

\begin{tabular}{|l|l|l|l|l|l|l|l|l|l|}
\hline & Teste 1 & Teste 2 & Teste 3 & Teste 4 & Teste 5 & Teste 6 & Teste 7 & Teste 8 & TOTAL \\
\hline Média & 0,0126 & 0,0142 & 0,0091 & 0,0191 & 0,0423 & 0,0498 & 0,0493 & 0,0854 & 0,0498 \\
\hline Máximo & 0,0147 & 0,0168 & 0,0092 & 0,0242 & 0,0483 & 0,0759 & 0,0673 & 0,1110 & 0,1110 \\
\hline Mínimo & 0,0082 & 0,0093 & 0,0091 & 0,0030 & 0,0135 & 0,0265 & 0,0386 & 0,0416 & 0,0030 \\
\hline Desvio padrão & 0,0020 & 0,0026 & 0,0001 & 0,0071 & 0,0102 & 0,0194 & 0,0074 & 0,0228 & 0,0331 \\
\hline Coef. Variação & 0,1585 & 0,1832 & 0,0067 & 0,3733 & 0,2406 & 0,3893 & 0,1512 & 0,2674 & 0,6635 \\
\hline
\end{tabular}

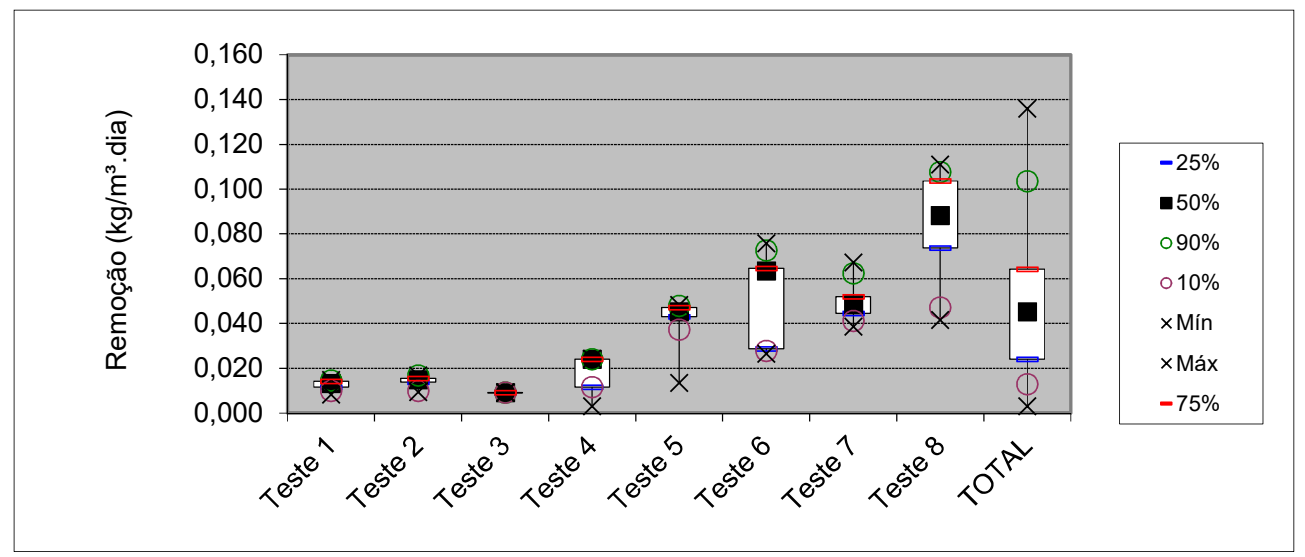

Figura 25 - Diagrama Boxplot - Remoção de N-NO $3^{-}\left(\mathrm{kg} / \mathrm{m}^{3} . \mathrm{dia}\right)$.

O valor médio de remoção de $0,0498 \pm 0,0331 \mathrm{~kg} / \mathrm{m}^{3}$.dia é próximo àquele apresentado por Pous et al. (2013) $\left(0,051 \mathrm{~kg} / \mathrm{m}^{3} . \mathrm{dia}\right)$.

\subsection{Nitrito no efluente tratado}

Concentrações de nitrito foram medidas em todas as fases dos testes (Tabela 16). A concentração média ficou em $0,36 \pm 0,37 \mathrm{mg} \mathrm{N}-\mathrm{NO}_{2}-1 / \mathrm{L}$. O Teste 4 , que registrou a melhor eficiência de remoção de nitrato, também obteve as menores concentrações de nitrito. Nota-se pelo diagrama boxplot (Figura 26) que os maiores valores de nitrito foram medidos no Teste 5 , teste este em que o sistema teve seu primeiro aumento na vazão de entrada e diminuição do 
TDH para 3,8 h. O sistema foi se estabilizando no Teste 6 e, no Teste 7, as concentrações de N$\mathrm{NO}_{2}{ }^{-}$baixaram para $0,16 \pm 0,1 \mathrm{mg} \mathrm{N}-\mathrm{NO}_{2}{ }^{-} / \mathrm{L}$ quando iniciou-se a aplicação de corrente externa.

Tabela 16 - Estatística da concentração de $\mathrm{N}-\mathrm{NO}_{2}^{-}$no efluente tratado (mg/L)

\begin{tabular}{|l|l|l|l|l|l|l|l|l|l|}
\hline & Teste 1 & Teste 2 & Teste 3 & Teste 4 & Teste 5 & Teste 6 & Teste 7 & Teste 8 & TOTAL \\
\hline Média & 0,20 & 0,32 & 0,16 & 0,06 & 0,74 & 0,70 & 0,16 & 0,35 & 0,36 \\
\hline Máximo & 0,59 & 0,87 & 0,18 & 0,61 & 1,40 & 1,74 & 0,37 & 0,67 & 1,74 \\
\hline Mínimo & 0,00 & 0,00 & 0,13 & 0,00 & 0,00 & 0,00 & 0,00 & 0,06 & 0,00 \\
\hline Desvio padrão & 0,17 & 0,32 & 0,04 & 0,17 & 0,49 & 0,45 & 0,10 & 0,21 & 0,37 \\
\hline $\begin{array}{l}\text { Coef. } \\
\text { Variação }\end{array}$ & 0,85 & 0,98 & 0,22 & 2,78 & 0,66 & 0,64 & 0,66 & 0,61 & 1,03 \\
\hline
\end{tabular}

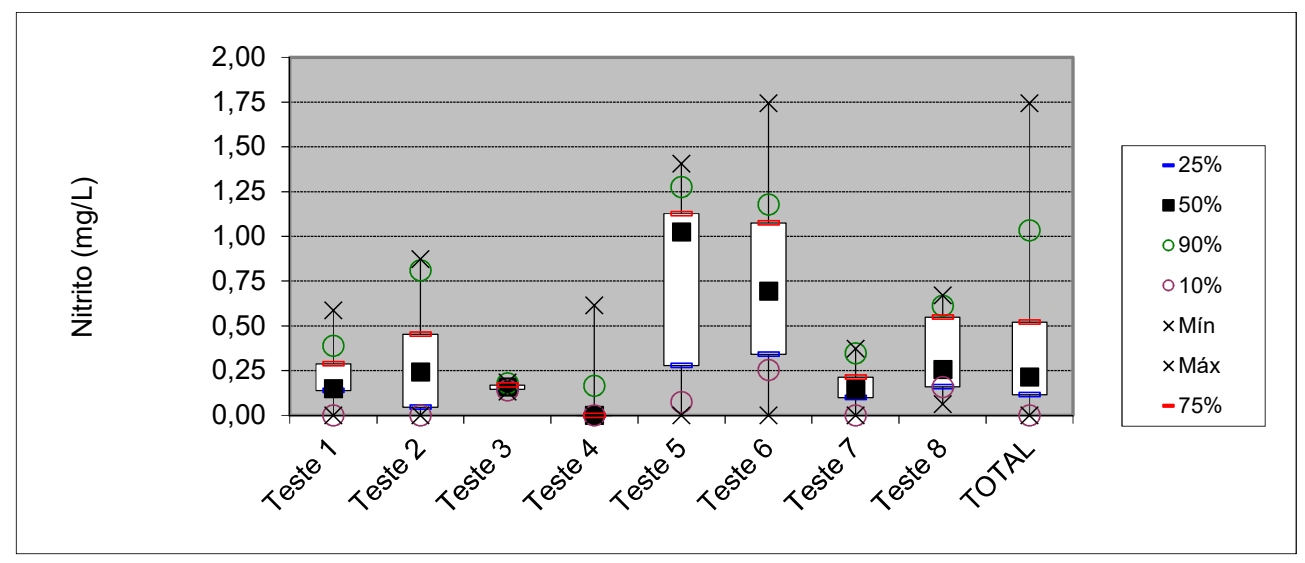

Figura 26 - Diagrama Boxplot - N-NO ${ }^{-}$no efluente tratado (mg/L).

À exceção dos Testes 5 e 6, as concentrações médias de nitrito não excederam o limite de potabilidade de $1 \mathrm{mg} \mathrm{N}-\mathrm{NO}_{2}-$ /L.

\subsection{Nitrato no compartimento anódico}

Além das análises de nitrato realizadas no efluente tratado proveniente da câmara catódica, também foram realizadas análises na solução de alimentação (fonte de carbono) e dentro do compartimento anódico visto a recirculação entre as câmaras. A solução de alimentação e a câmara anódica apresentaram concentrações médias de 0,03 \pm 0,09 mg N-NO $3^{-}$ $/ \mathrm{L}$ e 1,92 $\pm 2,27 \mathrm{mg} \mathrm{N}^{-N_{3}}{ }^{-} / \mathrm{L}$, respectivamente (Tabela 17). Apesar do valor médio de concentração, através do diagrama boxplot (Figura 27) nota-se que as concentrações dentro do

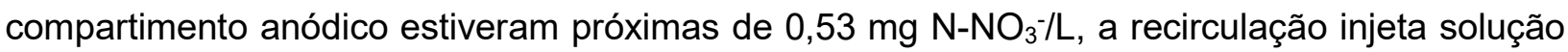
em fluxo ascendente, e ejeta de uma câmara para outra em fluxo descendente, sugerindo que o nitrato da câmara catódica para a anódica seja consumido no meio aderido. A baixa concentração de nitrato na câmara anódica limita a probabilidade de diluição do nitrato no sistema para valores não significativos, mas de monitoramento necessário. 
Tabela 17 - Medições de $\mathrm{N}-\mathrm{NO}_{3}{ }^{-}$no compartimento anódico.

\begin{tabular}{|l|l|l|}
\hline & $\mathrm{N}^{-N}{ }_{3}{ }^{-}$- Afluente & ${\mathrm{N}-\mathrm{NO}}^{-}{ }^{-}$- Dentro do Reator \\
\hline Unid. & $\mathrm{mg} / \mathrm{L}$ & $\mathrm{mg} / \mathrm{L}$ \\
\hline Média & 0,03 & 1,92 \\
\hline Máximo & 0,34 & 6,22 \\
\hline Mínimo & 0,00 & 0,00 \\
\hline Desvio padrão & 0,09 & 2,27 \\
\hline Coef. Var & 3,61 & 1,18 \\
\hline
\end{tabular}

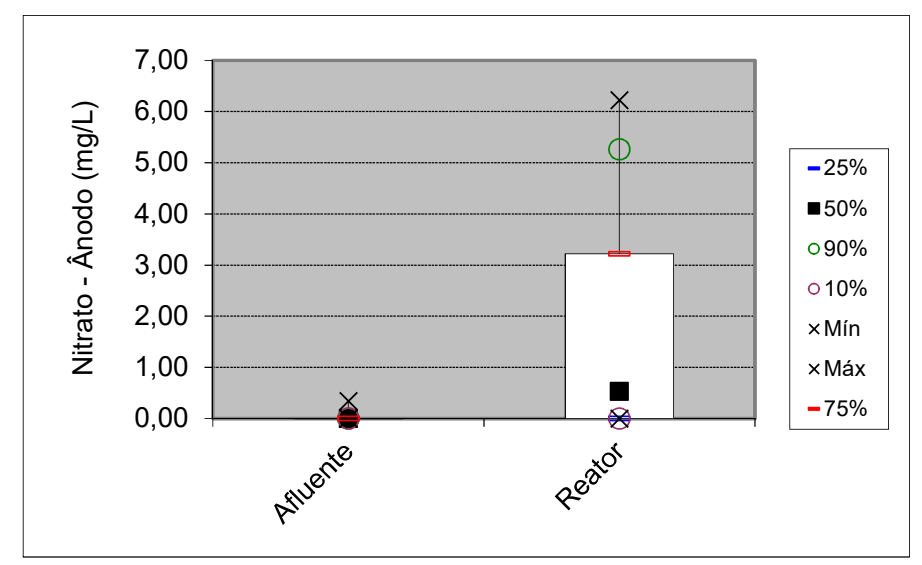

Figura 27 - Diagrama Boxplot - N-NO ${ }_{3}^{-}$no compartimento anódico (mg/L).

\subsection{Relação Alcalinidade x Remoção de Nitrato}

As medições de alcalinidade foram iniciadas a partir da fase de testes horários (Teste 4). A Figura 28 apresenta a concentração de nitrato do efluente tratado versus a concentração de alcalinidade das mesmas amostras. Nos Testes 4, 5 e 7, a concentração de nitrato decai sensivelmente, enquanto a alcalinidade em todos os testes não sofre grande variação.

No entanto se analisados os resultados de maneira geral, o diagrama boxplot (Figura 29) mostra um aumento da concentração de alcalinidade do Teste 4 até o Teste 6 e uma ligeira diminuição do Teste 6 até o Teste 8. Como discutido no item 3.2.1, a alcalinidade em geral tende a aumentar quando o processo de desnitrificação evolui. Observa-se que ocorreu desnitrificação em todos os testes, mas ela foi mais pronunciada naqueles em que não houve a aplicação de corrente. A alcalinidade média obtida, considerando todos os testes, foi de 272,13 $\pm 20,70 \mathrm{mg}$ $\mathrm{CaCO}_{3} / \mathrm{L}$. 

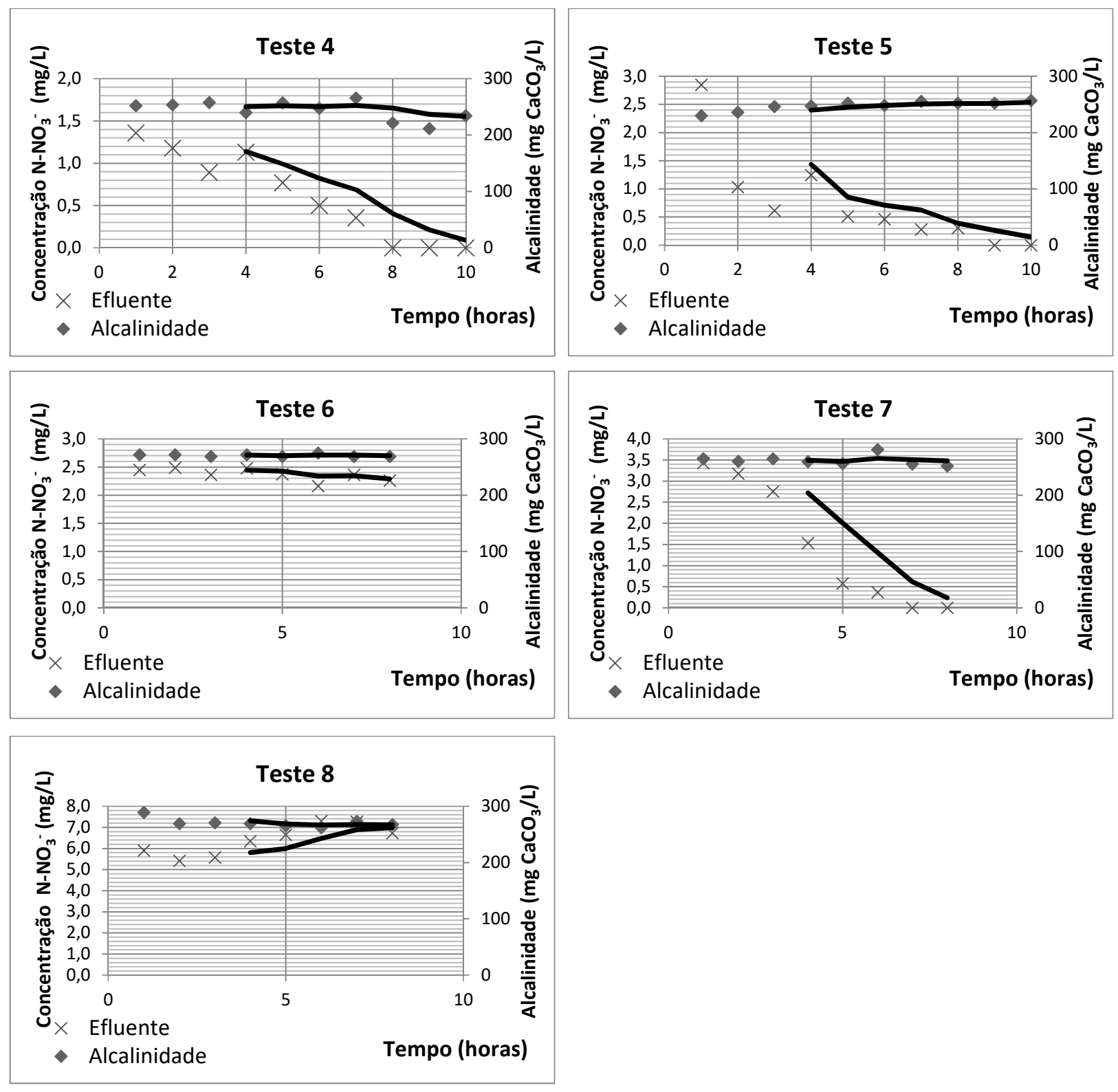

Figura 28 - Remoção de nitrato x Alcalinidade

Tabela 18 - Alcalinidade (mg $\mathrm{CaCO}_{3} / \mathrm{L}$ ) medida nos testes.

\begin{tabular}{|c|c|c|c|c|c|c|}
\hline Alcalinidade $\left(\mathrm{mg} \mathrm{CaCO}_{3} / \mathrm{L}\right)$ & Teste 4 & Teste 5 & Teste 6 & Teste 7 & Teste 8 & TOTAL \\
\hline Média & 244,13 & 261,39 & 291,08 & 272,40 & 265,24 & 272,13 \\
\hline Máximo & 265,85 & 310,40 & 336,00 & 296,80 & 288,96 & 336,00 \\
\hline Mínimo & 211,35 & 229,82 & 268,80 & 233,91 & 248,64 & 211,35 \\
\hline Desvio padrão & 17,26 & 19,35 & 19,69 & 14,47 & 10,76 & 20,70 \\
\hline Coef. Variação & 0,07 & 0,07 & 0,07 & 0,05 & 0,04 & 0,08 \\
\hline
\end{tabular}




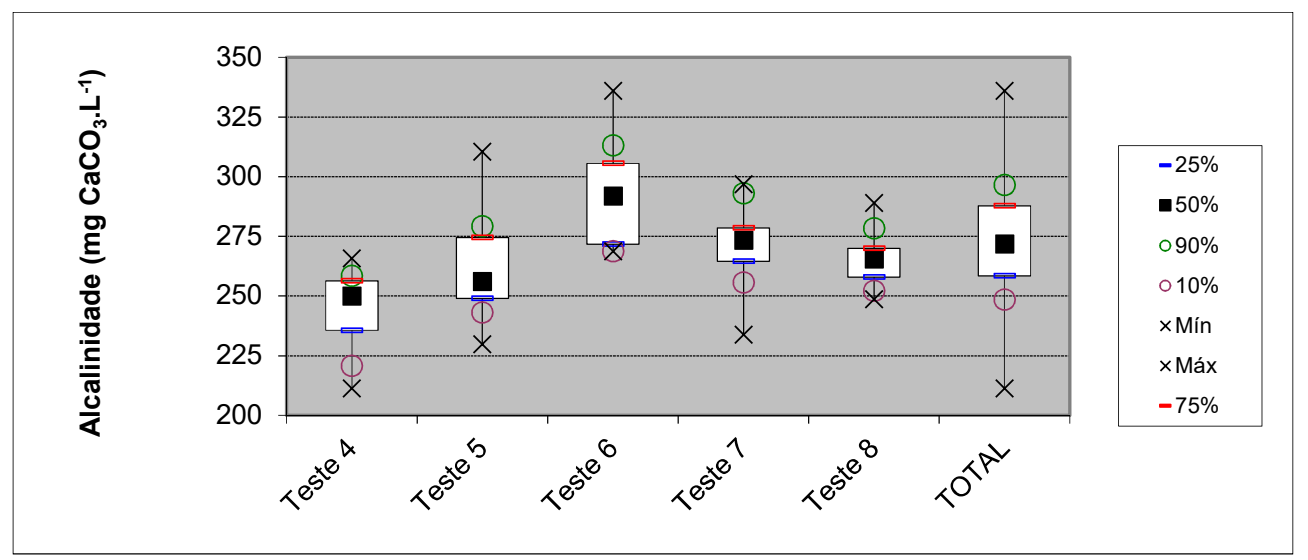

Figura 29 - Diagrama Boxplot - Alcalinidade (mg CaCO$/ 2 / L)$.

\subsection{Condutividade elétrica no processo bioeletroquímico}

O valor médio de condutividade foi de $1251 \pm 85 \mu \mathrm{S} / \mathrm{cm}$. Assim como a alcalinidade, a condutividade elétrica no efluente tratado foi medida a partir dos testes horários (Teste 4). A Figura 30 apresenta a concentração de nitrato do efluente tratado versus a condutividade elétrica das mesmas amostras. Nota-se que a condutividade elétrica (sais dissolvidos) diminui à medida que o $\mathrm{NO}_{3}{ }^{-}$é removido, já que se remove um ânion que pesa sobre a força iônica da solução.

Analisando as médias dos testes (Tabela 19) e o diagrama boxplot (Figura 31) com os valores da eficiência de remoção de nitrato apresentados na Figura 24 confirma-se tal relação, percebendo-se que a condutividade aumenta conforme a eficiência de remoção diminuiu ao longo dos testes. 

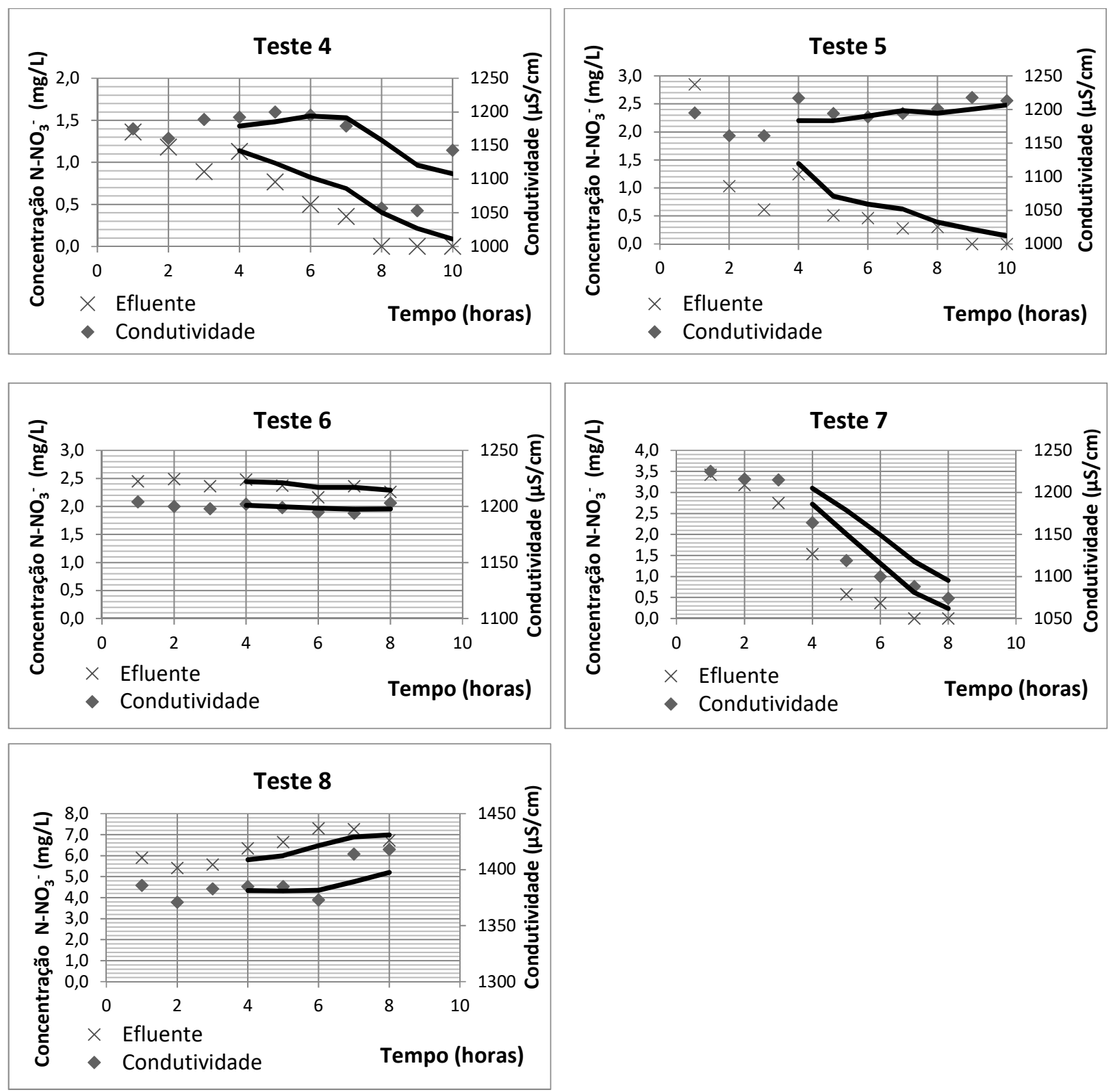

Figura 30 - Remoção de nitrato x Condutividade elétrica.

Tabela 19 - Estatística da condutividade elétrica $(\mu \mathrm{S} / \mathrm{cm})$ para os testes realizados.

\begin{tabular}{|l|l|l|l|l|l|l|}
\hline Condutividade $(\boldsymbol{\mu S} / \mathbf{c m})$ & Teste 4 & Teste 5 & Teste 6 & Teste 7 & Teste 8 & TOTAL \\
\hline Média & 1154 & 1195 & 1254 & 1246 & 1364 & 1251 \\
\hline Máximo & 1200 & 1218 & 1327 & 1341 & 1418 & 1418 \\
\hline Mínimo & 1053 & 1161 & 1124 & 1074 & 1175 & 1053 \\
\hline Desvio padrão & 55 & 17 & 60 & 71 & 63 & 85 \\
\hline Coef. Variação & 0,05 & 0,01 & 0,05 & 0,06 & 0,05 & 0,07 \\
\hline
\end{tabular}




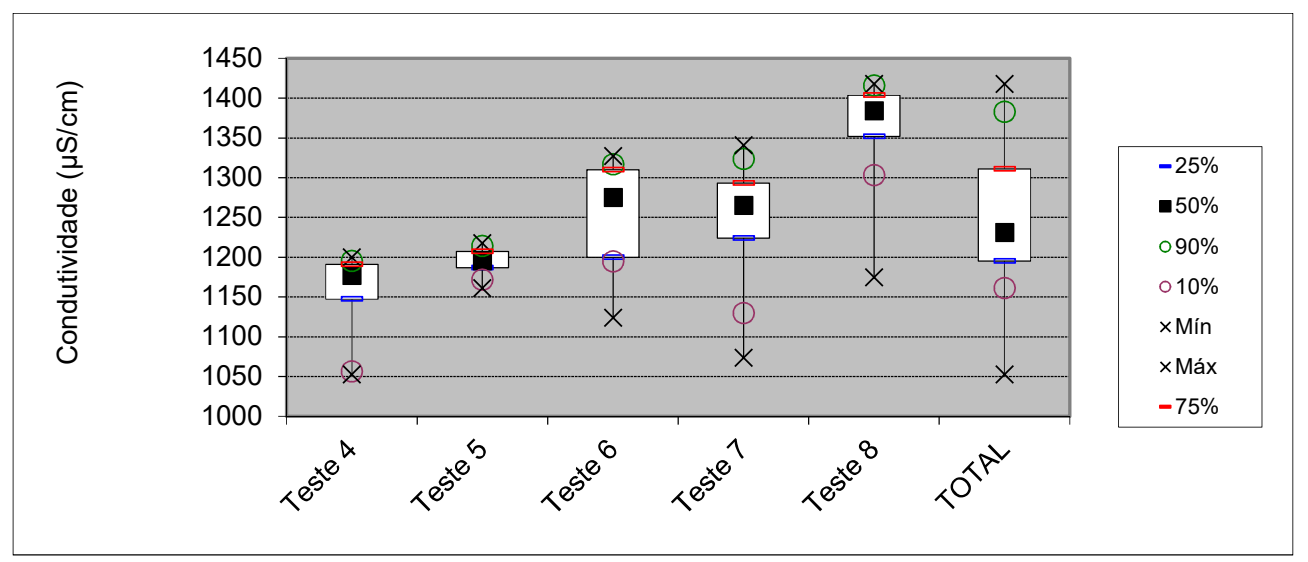

Figura 31 - Diagrama Boxplot - Condutividade ( $\mu \mathrm{S} / \mathrm{cm})$

\subsection{Crescimento Bacteriano}

Os microrganismos no sistema foram monitorados apenas de maneira visual. Em todas as fases do experimento, notou-se crescimento bacteriano (Figura 32), o que dispensou a reposição do inóculo. Em algumas vezes foi necessário o desentupimento da mangueira de retirada da água tratada do sistema.

No início do experimento, os microrganismos encontravam-se aderidos ao material granular. No entanto, após 20 a 30 dias já era possível ver colônias sobre o material granular (Figura 32-A). Nas fases seguintes, os microrganismos continuavam a ser vistos sobre o material granular (Figura 32-B), e por volta do Teste 3 (Figura 32-C) somente se notavam microrganismos aderidos. A partir desse teste, notou-se um aumento na formação de bolhas de gases no compartimento catódico, que continuou pelas fases seguintes (Figura 32-D, E e F), até que nos Testes 7 e 8 (Figura 32-G e H) foi necessária retirada de parte dos flocos de microrganismos em suspensão, devido ao entupimento frequente da mangueira de saída.

Apesar do aspecto do reator, a água tratada não apresentava cor ou turbidez, embora tais parâmetros não tenham sido analiticamente medidos. 


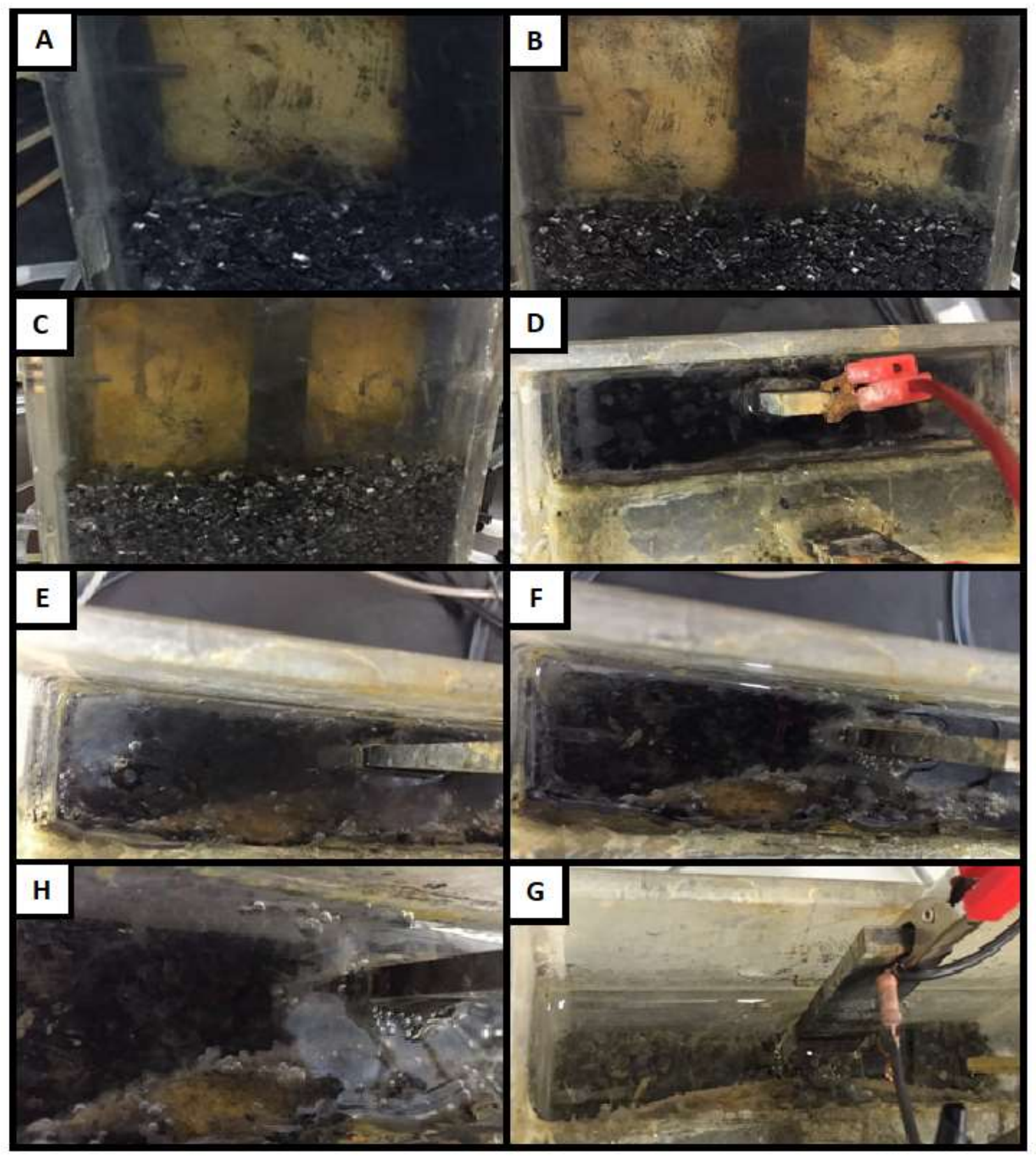

A - Ânodo - Teste 1: Crescimento bacteriano sobre o material granular

B - Ânodo - Teste 2: Crescimento bacteriano sobre o material granular

C - Ânodo - Teste 3: Crescimento bacteriano somente aderido no material granular

D - Cátodo - Teste 4: Surgimento de bolhas de gás

E - Cátodo - Teste 5: Aumento das bolhas de gás

F - Cátodo - Teste 6: Aumento das bolhas de gás

G - Cátodo - Teste 7: Aumento das bolhas de gás

H - Cátodo - Teste 8: retirada de microrganismos suspensos, devido a entupimento frequente

Figura 32 - Crescimento bacteriano no sistema bioeletroquímico 


\subsection{Eficiência de Coulomb}

A eficiência de Coulomb foi calculada a partir do Teste 3, quando o sistema bioeletroquímico passou a operar em circuito fechado (Tabela 20 e Figura 33). A eficiência média foi de $10,39 \pm 17,68 \%$. O Teste 7 obteve os melhores resultados de eficiência, seguido pelo Teste 8, ensaios nos quais houveram aplicação de corrente externa. Dentre os testes sem aplicação de corrente, o Teste 4 obteve o melhor desempenho de eficiência, juntamente com a eficiência de remoção de nitrato. O mais alto valor de eficiência de Coulomb em um sistema bioeletroquímico para remoção de nitrato foi reportado por Pous et al. (2013) (80\%) e o menor por Tong e He (2013) (15\%) (Tabela 6).

Tabela 20 - Estatística da Eficiência de Coulomb (\%) para os testes realizados

\begin{tabular}{|l|l|l|l|l|l|l|l|}
\hline & Teste 3 & Teste 4 & Teste 5 & Teste 6 & Teste 7 & Teste 8 & TOTAL \\
\hline Média & 1,83 & 2,51 & 0,93 & 0,96 & 30,03 & 7,85 & 10,39 \\
\hline Máximo & 2,45 & 18,38 & 2,06 & 3,36 & 73,05 & 53,64 & 73,05 \\
\hline Mínimo & 1,21 & 0,46 & 0,23 & 0,17 & 0,17 & 0,10 & 0,08 \\
\hline Desvio padrão & 0,87 & 4,39 & 0,56 & 0,82 & 21,43 & 13,16 & 17,68 \\
\hline Coef. Variação & 0,48 & 1,75 & 0,60 & 0,85 & 0,71 & 1,68 & 1,70 \\
\hline
\end{tabular}

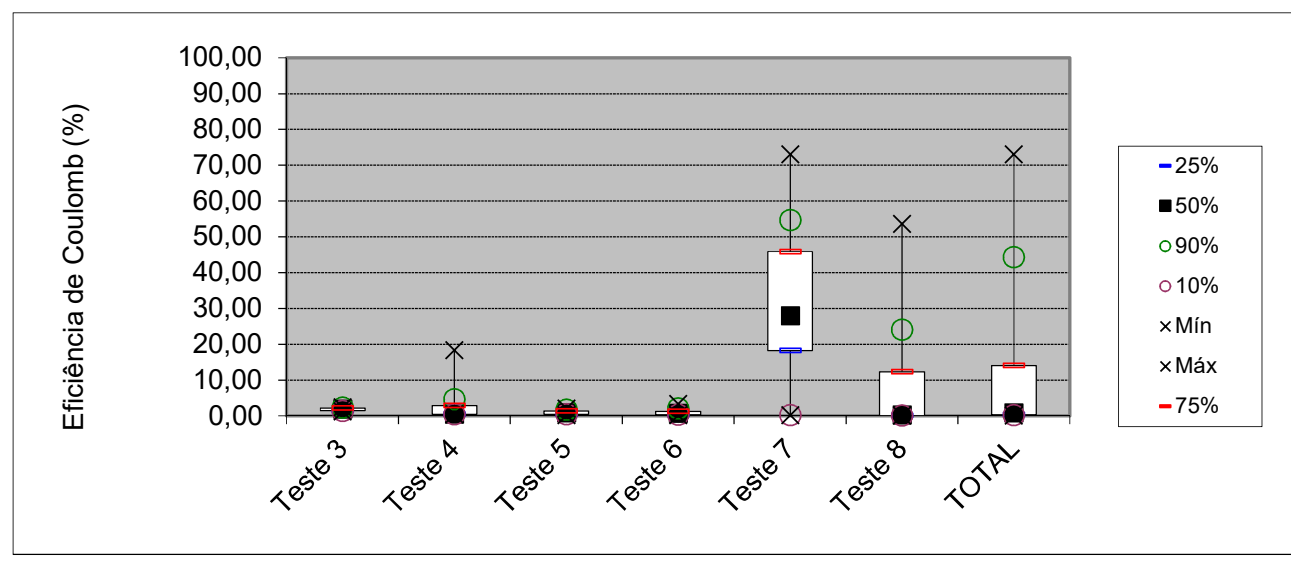

Figura 33 - Diagrama Boxplot - Eficiência de Coulomb (\%)

Analisando os resultados e a metodologia de cálculo, nota-se que a corrente elétrica é a variável mais sensível desse parâmetro. A geração de corrente foi percebida desde o início das medições, no entanto os valores aferidos não aumentaram ao longo do experimento.

A corrente elétrica foi medida através de um multímetro de forma pontual, ou seja, a cada coleta de dados foi realizada uma medição de corrente. É possível que o cálculo deste parâmetro tenha sido prejudicado por falta de dados. 


\subsection{Densidade de corrente}

A densidade de corrente média considerando todos os testes foi de $393,84 \pm 854,41 \mathrm{~mA} / \mathrm{m}^{3}$ (Tabela 21 e Figura 34). Nota-se que os valores obtidos nos Testes 7 e 8 são destoantes em relação aos demais: a média dos Testes 3 a 6 correspondeu a 0,823 $\pm 1,54 \mathrm{~mA} / \mathrm{m}^{3}$ (ou 0,0008 \pm $0,002 \mathrm{~A} / \mathrm{m}^{3}$ ) e a média dos Testes 7 e 8 foi de $872,021 \pm 1099,8 \mathrm{~mA} / \mathrm{m}^{3}$ (ou $0,87 \pm 1,1 \mathrm{~A} / \mathrm{m}^{3}$ ).

A densidade de corrente obteve melhores resultados com a aplicação externa de corrente (Testes 7 e 8), indicando que para geração de corrente no processo bioeletroquímico é interessante dar uma partida aplicando-se corrente externa. No entanto, verificou-se que esse fator não beneficiou sensivelmente a eficiência de remoção de nitrato como visto no item 5.2.

Tabela 21 - Estatística da Densidade de corrente $\left(\mathrm{mA} / \mathrm{m}^{3}\right)$ para os testes realizados

\begin{tabular}{|l|l|l|l|l|l|l|l|}
\hline & Teste 3 & Teste 4 & Teste 5 & Teste 6 & Teste 7 & Teste 8 & TOTAL \\
\hline Média & 0,12 & 0,47 & 0,82 & 1,15 & 1191,28 & 358,43 & 393,84 \\
\hline Máximo & 0,19 & 3,02 & 3,02 & 10,61 & 4272,37 & 1905,15 & 4272,37 \\
\hline Mínimo & 0,05 & 0,05 & 0,05 & 0,05 & 0,05 & 0,05 & 0,05 \\
\hline Desvio padrão & 0,10 & 0,81 & 0,94 & 2,24 & 1206,71 & 643,35 & 854,41 \\
\hline Coef. Variação & 0,85 & 1,74 & 1,15 & 1,94 & 1,01 & 1,79 & 2,17 \\
\hline
\end{tabular}
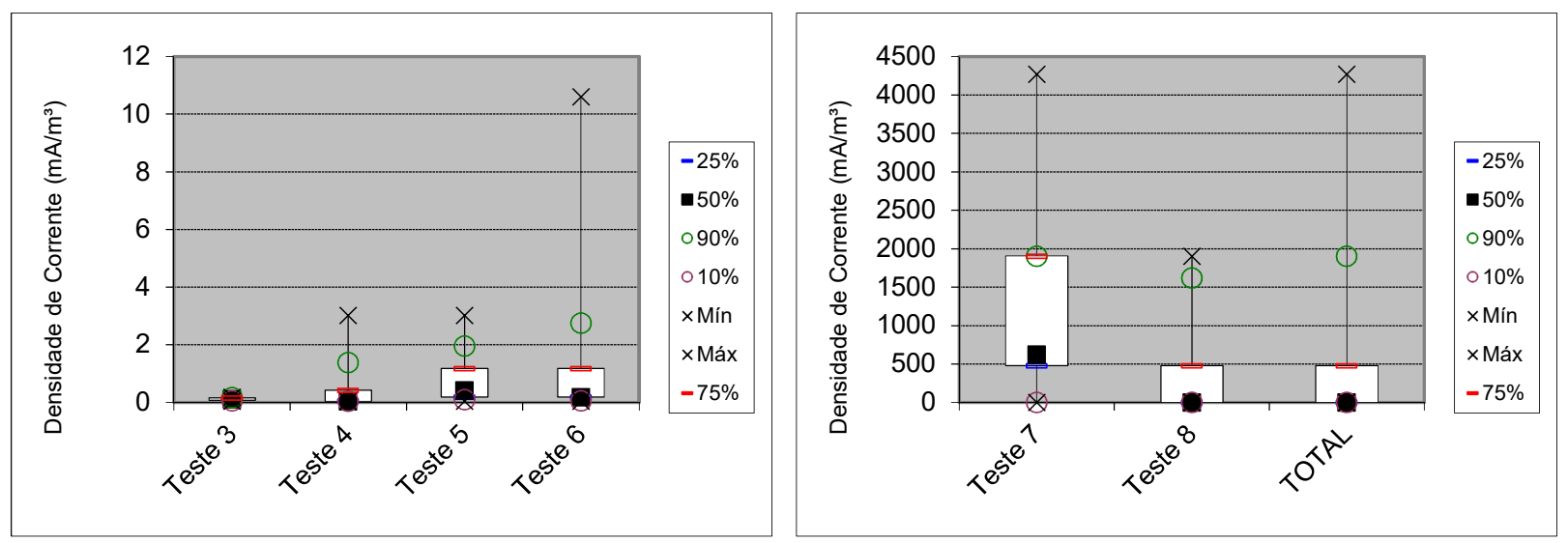

Figura 34 - Diagrama Boxplot - Densidade de corrente $\left(\mathrm{mA} / \mathrm{m}^{3}\right)$

Os valores obtidos no experimento foram bem inferiores àqueles obtidos em estudos da literatura $\left(8,73 \mathrm{~A} / \mathrm{m}^{3}\right.$, Tabela 6$)$. Tendo em vista que a corrente elétrica para cálculo desse parâmetro também é uma variável sensível, é possível que a obtenção da densidade de corrente também tenha sido prejudicada pela falta de dados.

\subsection{Geração de $\mathrm{N}_{2} \mathrm{O}$}

Não foi possível fazer a análise dos gases e das bolhas de gases geradas no reator. Entretanto, estimou-se a geração de $\mathrm{N}_{2} \mathrm{O}$ (Figura 35) a partir da correlação entre os valores médios de eficiência de Coulomb dos Testes 3 a 8 e os resultados obtidos por Virdis et al. (2009). A metodologia de cálculo sugere que a eficiência de Coulomb é inversamente proporcional à 
geração de $\mathrm{N}_{2} \mathrm{O}$ no sistema bioeletroquímico. Feita essa consideração, deduz-se que os Testes 7 e 8, com melhor eficiência de Coulomb, em teoria gerariam menos $\mathrm{N}_{2} \mathrm{O}$ ou mais $\mathrm{N}_{2}$.

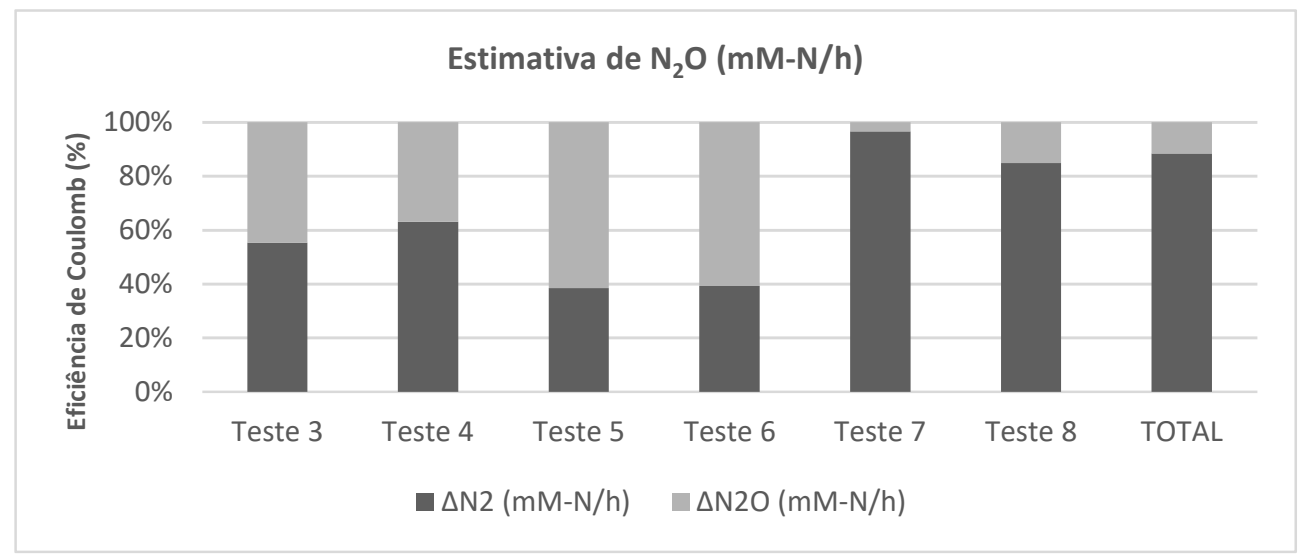

Figura 35 - Estimativa $\mathrm{N}_{2} \mathrm{O}(\mathrm{mM}-\mathrm{N} / \mathrm{h})$ 


\section{CONCLUSÕES}

Diante dos resultados obtidos, concluiu-se que o sistema bioeletroquímico desempenhou de maneira bastante satisfatória seu papel em remover nitrato das águas subterrâneas por meio da desnitrificação biológica.

A eficiência média de remoção de nitrato através do sistema bioeletroquímico em águas subterrâneas foi de $80,84 \pm 16,73 \%$, chegando a alcançar o valor máximo de $100 \%$. As concentrações finais de nitrato, no efluente tratado, ficaram dentro do padrão de potabilidade de

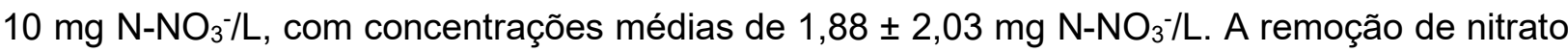
foi de $0,0498 \pm 0,03 \mathrm{~kg} / \mathrm{m}^{3}$.dia. A concentração média de nitrito correspondeu a 0,36 $\pm 0,37 \mathrm{mg}$ $\mathrm{N}-\mathrm{NO}_{2}{ }^{-} / \mathrm{L}$. Somente nos Testes 5 e 6 , o nitrito chegou a valores máximos de 1,40 e 1,74 mg N$\mathrm{NO}_{2}-1 \mathrm{~L}$, respectivamente, indicando a sensibilidade desse íon ao TDH aplicado ao sistema.

Concentrações de nitrato também foram medidas no compartimento anódico procurando identificar diluição da concentração no sistema por parte da recirculação entre as câmaras, os valores foram próximos de $0,53 \mathrm{mg} \mathrm{N}-\mathrm{NO}_{3}-1 / \mathrm{L}$

A eficiência de Coulomb média foi de 10,39 \pm 17,68\%. Testes com aplicação de corrente obtiveram melhor desempenho e também menor geração de $\mathrm{N}_{2} \mathrm{O}$ no sistema $(1,08 \mathrm{mM}-\mathrm{N} / \mathrm{h})$. A Densidade de corrente medida no sistema também resultou em melhor geração de corrente quando o sistema tem uma aplicação inicial de corrente externa.

A melhor eficiência de remoção de nitrato foi obtida no Teste 4 (95,66\%), no qual o sistema operou com TDH de 7,5 h e sem aplicação de corrente externa. Os resultados para acúmulo de nitrito também foram os menores, todavia o TDH maior - se comparado com os demais testes realizados no experimento - implicaria em um reator com dimensões maiores. A Eficiência de Coulomb e Densidade de Corrente foram baixas, de $2,51 \%$ e $0,47 \mathrm{~mA} / \mathrm{m}^{3}$, respectivamente, indicando uma geração maior de $\mathrm{N}_{2} \mathrm{O}$ no processo.

Já o Teste 7 que operou a um TDH 1,9 h, teve 76,67\% eficiência de remoção de nitrato, no entanto a concentração de nitrato no efluente tratado esteve dentro dos padrões estabelecidos pela legislação. O TDH operou com 3 vezes menos tempo, o que permitiria deixar o reator em um tamanho compacto. Este teste operou com aplicação de tensão externa, obtendo melhores desempenhos na eficiência de Coulomb (30,03 \%) e Densidade de Corrente $\left(1191,28 \mathrm{~mA} / \mathrm{m}^{3}\right)$. 


\section{RECOMENDAÇÕES}

O processo de remoção de nitrato através do sistema bioeletroquímico ainda possui pontos que carecem de maior investigação, como é o caso da viabilidade da aplicação de corrente para a performance do sistema.

No presente estudo identificaram-se alguns pontos que poderiam ser melhorados, como por exemplo a quantificação analítica de $\mathrm{N}_{2} \mathrm{O}$ no sistema. Visto que foi adotada uma metodologia indireta para estimativa deste parâmetro, não se pôde precisar quanto o sistema efetivamente gerou desse gás e a estimativa ainda ficou mais defasada visto sua relação com a eficiência de Coulomb que também teve sua estimativa prejudicada pela medição de corrente que foi realizada maneira pontual. Recomenda-se, portanto, que a medição seja feita por um data logger, que meça os dados continuamente.

Recomenda-se também a realização de testes com água subterrânea real, para comparação com os dados obtidos neste estudo com as variáveis controladas, de forma a identificar se há algum elemento que prejudique a performance do sistema. Além disso, poderia haver a variação das fontes de carbono de forma a procurar solucionar dois problemas: a água contaminada por nitrato e os resíduos orgânicos, em um único processo, como seria o caso do uso de rejeito da indústria de álcool como fonte de carbono, ou adaptações das demais fontes de carbono de fácil acesso regional.

Por fim, recomenda-se a investigação da viabilidade econômica-operacional da implantação de um sistema bioeletroquímico perante as demais tecnologias existentes hoje no mercado. Sabe-se que existem alternativas com alta eficiência de remoção de nitrato que são inviabilizadas pelos altos custos de implantação, manutenção e operação. O sistema bioeletroquímico, apesar de ser um tratamento através de microrganismos desnitrificantes e com um potencial de geração de energia, carece de uma investigação neste sentido para efetivamente consolidar-se como alternativa de remoção de nitrato. 


\section{REFERÊNCIAS BIBLIOGRÁFICAS}

1. Aelterman, P.; RABAEY, K.; PHAM, T. H.; BOON, N.; VERSTRAete, W.. Continuous electricity generation at high voltages and currents using stacked microbial fuel cells. Environmental science \& technology, v. 40, n. 10, p. 3388-3394, 2006.

2. AMERICAN PUBLIC HEALTH ASSOCIATION - APHA. Standard methods for the examination of water and wastewater. 21a ed. Washington, 2005.

3. ALABURDA, Janete; NISHIHARA, Linda. Presença de compostos de nitrogênio em águas de poços. Revista Saúde Pública, 32 (2): 160-165, 1998.

4. AQUINO, Alexandre de. As diferenças entre nanofiltração, ultrafiltração, microfiltração e osmose reversa. Revista e portal meio filtrante. Ano X - Ed. $n^{\circ} 53$. Disponível

em: <http://www.meiofiltrante.com.br/materias_ver.asp?id=740\&revista=n53>. Publicado em: Nov/ 2011

5. AVERY, Alex; L'HIRONDEL, Jean-Louis. Nitrate and Methemoglobinemia. Environmental Health Perspectives. Vol. 111. n. 3. 2003.

6. BANASIAK, Laura J.; KRUTTSCHNITT, Thomas W.; SCHÄFER, Andrea I. Desalination using electrodialysis as a function of voltage and salt concentration. Desalination, v. 205, n. 1, p. 38-46, 2007.

7. BEG, Shafkat. A.; HASSAN, Mirza M.; CHAUDHRY, Muhammad A. S.. Effect os sinusoidal perturbations of feed concentration on multi-substrate carbon oxidation and nitrification process in an upflow packed-bed biofilm reactor. Chemical Engineering Journal, v. 65, pp. 165-174, 1997.

8. BITTON, Gabriel. Wastewater microbiology. John Wiley \& Sons, 2005.

9. BOROLE, Abhijeet P.; REGUERA, Gemma; RINGEISEN, Bradley; WANG, Zhi-Wu; FENG, Yujie; KIM, Byung $\mathrm{H}$.. Electroactive biofilms: Current status and future research needs. Energy Environ. Sci., 2011, 4, 4813, 2011.

10. BRADY, N. C.; WEIL, R. R. Soil phosphorus and potassium. The Nature and Properties of Soils (13th Ed.). Upper Saddle River, NJ: Prentice-Hall, Inc, 2002.

11. BRASIL. Ministério da Saúde. Portaria $n^{\circ} 2.914$ de 12 de dezembro de 2011. Dispõe sobre os procedimentos de controle e de vigilância da qualidade da água para consumo humano e seu padrão de potabilidade. Diário oficial da União, 2011.

12. BULLEN, R. A.; ARNOT, T. C.; LAKEMAN, J. B.; WALSH, F. C.. Biofuel cells and their development. Biosensors and Bioelectronics, 21(11), 2015-2045, 2006.

13. CAMPBELL, Mary. K.; FARRELL, Shawn. O.. Bioquímica - Volume 1 - Básico. São Paulo, São Paulo, Brasil: Cengage Learning Edições Ltda., 2010.

14. CAMPOS, J.L.; GARRIDO, J.M.; MOSQUERA-CORRAL, A.; M'ENDEZ, R. Stability of a nitrifying activated sludge reactor. Department of Chemical Engineering, University of Santiago de Compostela, School of Engineering, Spain. 2007.

15. CLAUWAERT, P.; RABAEY, K.; AELTERMAN, P.; DE SCHAMPHELAIRE, L.; PHAM, T. H.; BOECKX, P., ... \& VERSTRAETE, W.. Biological denitrification in microbial fuel cells. Environmental science \& technology, v. 41, n. 9, p. 3354-3360, 2007.

16. CENTERS FOR DISEASE CONTROL AND PREVENTION - CDC. Methemoglobinemia Attributable to Nitrite Contamination of Potable Water Through Boiler Fluid Additives -- New Jersey, 1992 and 1996. Disponível em: <http://www.cdc.gov/mmwr/preview/mmwrhtmL/00046656.htm>. Publicado em: 19/09/1998. 
17. CESARINO, Alessandro. Seleção de materiais para remediação de aquíferos contaminados por nitrato através de barreiras reativas. Tese de Doutorado. Universidade de São Paulo. 2002.

18. COMPANHIA DE TECNOLOGIA DE SANEAMENTO AMBIENTAL - CETESB. Relatório de Qualidade das Águas Subterrâneas no Estado de São Paulo - 1994. São Paulo Brasil, 1996.

19. COMPANHIA DE TECNOLOGIA DE SANEAMENTO AMBIENTAL - CETESB. Qualidade das Águas Subterrâneas no Estado de São Paulo. Relatório, 2010-2012. São Paulo Brasil, 2013.

20. COMPANHIA DE TECNOLOGIA DE SANEAMENTO AMBIENTAL - CETESB. Qualidade das Águas Subterrâneas no Estado de São Paulo. Relatório, 2013-2015. São Paulo Brasil, 2016.

21. CLARK, Ian D.; FRITZ, Peter. Environmental Isotopes in Hydrogeology. Lewis Publishers, 1997

22. CLIFFORD, D.; LIU, X.. Ion exchange for nitrate removal. Journal AWWA - American Water Works Association. 85(4).p.135-143, 1993.

23. DARBI, A.; VIRARAGHAVAN, T.; BUTLER, R.; CORKAL, D.. Comparative evaluation of nitrate removal Technologies. 2002. Disponível em: < http://www.researchgate.net/publication/266267287_COMPARATIVE_EVALUAEVAL_O F_NITRATE_REMOVAL_TECHNOLOGIES>. Acesso em: 02/09/2015.

24. DU, Zhuwei; LI, Haoran; GU, Tingyue. A state of the art review on microbial fuel cells: a promising technology for wastewater treatment and bioenergy. Biotechnology advances, 25.5: 464-482, 2007.

25. EGLI, K.; BOSSHARD, F.; WERLEN, C.; LAIS, P.; SIEGRIST, H.; ZEHNDER AJ.; VAN DER MEER JR. Microbial composition and structure of a rotating biological contactor biofilm treating ammonium-rich wastewater without organic carbon. Microb Ecol. 2003 May;45(4):419-32, 2003.

26. FARIAS, Ana Maria Lima de. O Boxplot. Universidade Federal Fluminense. Instituto de Matemática. Conteúdos Digitais em Matemática e Estatística, 2009.

27. FEWTRELL, Lorna. Drinking-Water Nitrate, Methemoglobinemia, and Global Burden of Disease: A Discussion. Centre for Research into Environment and Health, Crewe, Cheshire, United Kingdom. Environmental Health Perspectives. Vol. 112. n. 14. 2004.

28. FLERE, Joel M.; Zhang, Tian C.. Nitrate Removal with Sulfur-Limestone Autotrophic Denitrification Processes. Journal of Environmental Engineering. 125:721-729, 1999.

29. FREEZE, R. Allan; CHERRY, John A.. Groundwater. Prentice Hall; $1^{\text {th }}$ edition, 1979.

30. FUCHS, W.; SCHATZMAYR, G.; BRAUN, R.. Nitrate removal from drinking water

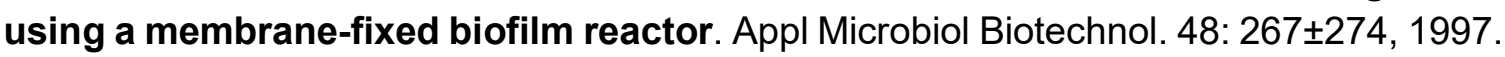

31. GHAFARI, S.; HASAN, M.; AROUA, M.K. Bio-electrochemical removal of nitrate from water and wastewater-a review. Bioresour. Technol. 99, 3965, 2008.

32. GREGORY, K.B.; BOND, D.R.; LOVLEY, D.R.. Graphite electrodes as electron donors for anaerobic respiration. Environ. Microbiol. 6, 596-604, 2004.

33. HAMLIN, H. J.; MICHAELS, J. T.; BEAULATON, C. M.; GRAHAM, W. F.; DUTT, W.; STEINBACH, P.; LOSORDO, T.M.; Schrader, K. K.; Main, K. L.. Comparing denitrification rates and carbon sources in commercial scale upflow denitrification biological filters in aquaculture. Aquacultural engineering, v. 38, n. 2, p. 79-92, 2008.

34. HE, Zhen; MINTEER, Shelley D.; ANGENENT, Largus T. Electricity generation from artificial wastewater using an upflow microbial fuel cell. Environmental science \& technology, v. 39, n. 14, p. 5262-5267, 2005. 
35. HENZE, Mogens. Wastewater treatment: biological and chemical processes. Springer Science \& Business Media, 2002.

36. HIRATA, Ricardo. Nitrato nas águas subterrâneas: caracterização, remediação e políticas no Brasil. Tese de Livre Docência. Instituto de Geociências, USP, São Paulo, 2012.

37. HOEK, Jan Peter Van Der; KLAPWIJK, Abraham. Nitrate Removal from Groundwater. Wageningen Agricultural University, Department of Water Pollution Control. De Dreyen 12, 6703 BC Wageningen, The Netherlands, 1987.

38. HYPOLITO, Raphael; ANDRADE, Sandra; EZAKI Sibele. Geoquímica da interação: água, rocha, solo: estudos preliminares. São Paulo: All Print Editora, 2011.

39. INSTITUTO NACIONAL DE CÂNCER - INCA. Câncer no estômago. Ministério da Saúde, Rio de Janeiro. Disponível em: $<$ http://www2.inca.gov.br/wps/wcm/connect/tiposdecancer/site/home/estomago/prevenc ao>. Acesso em: 14/10/2015.

40. IRITANI, Mara Akie; EZAKI, Sibele. As águas subterrâneas do Estado de São Paulo. São Paulo: Secretaria de Estado do Meio Ambiente - SMA. 104p.: il. Color.; 23cm. ) - 2a. edição, 2009.

41. INTERSTATE TECHNOLOGY e REGULATORY COUNCIL - ITRC. Emerging Technologies for Enhanced In Situ Biodenitrification (EISBD) of NitrateContaminated Ground Water. Interstate Technology and Regulatory Cooperation Work Group Enhanced In Situ Biodenitrification Work Team, 2000.

42. KAPOOR, Anoop; VIRARAGHAVAN, T. Nitrate Removal from Drinking Water Review. Journal of Environmental Engineering, 1997.

43. KELLY, Patrick T.; He, ZHEN. Nutrients removal and recovery in bioelectrochemical systems: A review. Bioresource Technology 153 (2014) 351-360, 2014

44. KNOWLES, Roger. Denitrification. Microbiological Reviews, p. 43-70 Vol. 46, No. 1, 1982.

45. LEE, C. Y.; HO, K. L.; LEE, D. J.; SU, A.; CHANG, J. S.. Electricity harvest from nitrate/sulfide-containing wastewaters using microbial fuel cell with autotrophic denitrifier, Pseudomonas sp. C27. International Journal of Hydrogen Energy, 37(20), 15827-15832, 2012.

46. LIU, Hong; LOGAN, Bruce E. Electricity Generation Using an Air-Cathode Single Chamber Microbial Fuel Cell in the Presence and Absence of a Proton Exchange Membrane. Environmental science \& technology, v. 38, p. 4040-4046, 2004.

47. LIU, Hong; RAMNARAYANAN, Ramanathan; LOGAN, Bruce E. Production of electricity during wastewater treatment using a single chamber microbial fuel cell. Environmental science \& technology, v. 38, n. 7, p. 2281-2285, 2004.

48. LOGAN, B. E.; MURANO, C.; SCOTT, K.; GRAY, N. D.; HEAD, I. M.. Electricity generation from cysteine in a microbial fuel cell. Water Research, v. 39, n. 5, p. 942952, 2006

49. LOGAN, Bruce E.. Exoelectrogenic bacteria that power microbial fuel cells. Nature Reviews / Microbiology Vol. 7, 2009.

50. LOVLEY, Derek R. Microbial fuel cells: novel microbial physiologies and engineering approaches. Current opinion in biotechnology, v. 17, n. 3, p. 327-332, 2006.

51. LUNA-VELASCO, Antonia; SIERRA-ALVAREZ, Reyes; CASTRO, Beatriz; FIELD, Jim A.. Removal of Nitrate and Hexavalent Uranium From Groundwater by Sequential Treatment in Bioreactors Packed With Elemental Sulfur and Zero-Valent Iron. Department of Chemical and Environmental Engineering, University of Arizona, 2010. 
52. MACLAREN, R. G. CAMERON, K. C. Soil Science: Sustainable production and environmental protection. Auckland, Oxford University Press, 1996.

53. MANASSARAM, Deana M.; Backer, Lorraine C.; MESSING, Rita; FLEMING, Lora E.; LUKE, Barbara; MONTEILH, Carolyn P.. Nitrates in drinking water and methemoglobin levels in pregnancy: a longitudinal study. Environmental Health, v. 9, n. 60 , p. 1-12, 2010.

54. METCALF \& EDDY Inc.; Wastewater engineering: treatment and reuse. Tata McGrawHill Edition, 2003.

55. MEURER, E. J. Fundamentos de Química do Solo. $2^{\circ}$ Edição, Editora UFRGS, Porto Alegre, 2004.

56. MIERZWA, José C. Sistemas de troca iônica e eletrodiálise para tratamento de água (aula). Disciplina: PHD 5750 - Tratamento avançado de águas de abastecimento. Escola Politécnica - USP. 2011.

57. MIN, Booki; LOGAN, Bruce E. Continuous electricity generation from domestic wastewater and organic substrates in a flat plate microbial fuel cell. Environmental science \& technology, v. 38, n. 21, p. 5809-5814, 2004.

58. MOHSENI-BANDPI, Anoushiravan; ELLIOTT, David Jack; ZAZOULI, Mohammad Ali. Biological nitrate removal processes from drinking water supply-a review. Journal of Environmental Health Science and Engineering, v. 11, n. 1, p. 35, 2013.

59. OH, Sang-Eun; MIN, Booki; LOGAN, Bruce E. Cathode performance as a factor in electricity generation in microbial fuel cells. Environmental science \& technology, $v$. 38 ed. 18, p. 4900-4904, 2004.

60. OH, Sang-Eun; LOGAN, Bruce E. Proton exchange membrane and electrode surface areas as factors that affect power generation in microbial fuel cells. Applied microbiology and biotechnology, v. 70, p.162-9, 2006.

61. OLIVEIRA, Andreliza C. D. G.. Bactérias Heterotróficas e Autotróficas envolvidas na Remoção de Nitrogênio de Lixiviado de Aterro Sanitário em Reator de Leito Móvel. (Dissertação de mestrado). Programa de Pós-Graduação em Engenharia de Edificações e Saneamento do Centro de Tecnologia e Urbanismo. Universidade Estadual de Londrina - UEL, 2012.

62. ORGANIZAÇÃO MUNDIAL DA SAÚDE - OMS. Nitrate and nitrite in drinking-water. WHO Guidelines for Drinking-water Quality, 2011.

63. PANT, Deepak; BOGAERT, Gilbert Van; DIELS, Ludo; VANBROEKHOVEN, Karolien. A review of the substrates used in microbial fuel cells (MFCs) for sustainable energy production. Bioresource technology, v. 101, n. 6, p. 1533-1543, 2009.

64. PEARSON, David. Escolhendo a Membrana Correta. Membrane Specialists, LLC. Disponível em: <http://www.membranespecialists.com/global/ptb/choosing-the-rightmembrane.php>. Acesso em: 21/11/2015.

65. PINTAR, Albin; BATISTA, Jurka; LEVEC, Janez. Integrated ion exchange/catalytic process for efficient removal of nitrates from drinking water. Chemical engineering science, v. 56, n. 4, p. 1551-1559, 2001.

66. POTTER, Michael C. Electrical effects accompanying the decomposition of organic compounds. Proceedings of the Royal Society of London. Series B, Containing Papers of a Biological Character, v. 84, n. 571, p. 260-276, 1911.

67. POUS, Narcis; PUIG, Sebastià; COMA, Marta; BALAGUER, Maria D.; COLPRIM, Jesus. Bioremediation of nitrate-polluted groundwater in a microbial fuel cell. Journal of Chemical Technology and Biotechnology, v. 88, n. 9, p. 1690-1696, 2013. 
68. PUIG, S.; COMA, M.; DESLOOVER, J.; BOON, N.; COLPRIM, J.; BALAGUER, M. D.. Autotrophic denitrification in microbial fuel cells treating low ionic strength waters. Environmental science \& technology, 46(4), 2309-2315, 2012.

69. RABAEY, Korneel; VERSTRAETE, Willy. Microbial fuel cells: novel biotechnology for energy generation. TRENDS in Biotechnology, v. 23, n. 6, p. 291-298, 2005.

70. RABAEY1 , K.; BOON, N.; SICILIANO, S. D.; VERHAEGE, M.; VERSTRAETE, W.. Microbial phenazine production enhances electron transfer in biofuel cells. Environmental science \& technology, v. 39, n. 9, p. 3401-3408, 2005.

71. RABAEY2, K.; OSSIEUR, W.; VERHAEGE, M.; VERSTRAETE, W.. Continuous microbial fuel cells convert carbohydrates to electricity. Water Science and Technology, v. 52, n. 1-2, p. 515-523, 2005.

72. RAUTENBACH, R.; KOPP, W.; VAN OPBERGEN, G.; HELLEKES, R.. Nitrate reduction of well water by reverse osmosis and electrodialysis-studies on plant performance and costs. Desalination, v. 65, p. 241-258, 1987.

73. REIS, M. M. INE 7001 Análise de Séries Temporais. Disciplina: INE 7001 - Estatística para Administradores I. UFSC, 2017.

74. RESENDE, Álvaro V. Agricultura e qualidade da água: contaminação da água por nitrato. Plantina: Embrapa Cerrados, 2002.

75. RIBEIRO, M. L.; DE LUCA, S. J.. Tratamento de águas por infiltração por membranas: estado da arte. Asociación Peruana de Ingeniería Sanitaria y Ambiental; AIDIS. Gestión ambiental en el siglo XXI. Lima, APIS, 1998

76. RIVETT, Michael O.; BUSS, Stephen R.; MORGAN, Philip; SMITH, Jonathan W.N.; BEMMENT, Chrystina D. Nitrate attenuation in groundwater: a review of biogeochemical controlling processes. Water research, v. 42, n. 16, p. 4215-4232, 2008.

77. ROSENBAUM, Miriam; SCHRÖDER, Uwe; SCHOLZ, Fritz. In situ electrooxidation of photobiological hydrogen in a photobioelectrochemical fuel cell based on Rhodobacter sphaeroides. Environmental science \& technology, v. 39, n. 16, p. 63286333, 2005.

78. ROZENDAL, René A.; HAMELERS, Hubertus V. M.; BUISMAN Cees J. N. Effects of Membrane Cation Transport on $\mathrm{pH}$ and Microbial Fuel Cell Performance. Environmental science \& technology, v. 40 p. 5206-5211, 2006.

79. SAEEDI, Reza; NADDAFI Kazem; NABIZADEH, Ramin; MESDAGHINIA, Alireza; NASSERI, Simin; ALIMOHAMMADI, Mahmood; NAZMARA, Shahrokh. Simultaneous Removal of Nitrate and Natural Organic Matter from Drinking Water Using a Hybrid Heterotrophic/Autotrophic/Biological Activated Carbon Bioreactor. Environmental engineering science, v. 29, n. 2, p. 93-100, 2012.

80. SAWYER, Clair N.; MCCARTY, Perry L.; PARKIN, Gene F. Chemistry for Environmental Engineering and Science. McGrawHill. New York, 2003.

81. SCHIPPER, Louis A.; ROBERTSONB, Will D.; GOLDC, Arthur J.; JAYNESD, Dan B.; CAMERONE, Stewart C. Denitrifying bioreactors-an approach for reducing nitrate loads to receiving waters. Ecological Engineering, v. 36, n. 11, p. 1532-1543, 2010.

82. SILVA, Verónica; POIESZ, Edwin; VAN DER HEIJDEN, Peter. Industrial wastewater desalination using electrodialysis: evaluation and plant design. Journal of Applied Electrochemistry, v. 43, n. 11, p. 1057-1067, 2013.

83. SMITH, Russel. Membrane Processes: an Overview. Modern Techniques in Water and Wastewater Treatment. East Melbourne, Vic., Australia, 1996.

84. TAIZ, Lincoln; ZEIGER, Eduardo. Fisiologia Vegetal. $4^{\circ}$ Edição, Editora Artmed, Porto Alegre, 2009. 
85. TONG, Yiran; HE, Zhen. Nitrate removal from groundwater driven by electricity generation and heterotrophic denitrification in a bioelectrochemical system. Journal of hazardous materials, v. 262, p. 614-619, 2013.

86. UNITED STATES ENVIRONMENTAL PROTECTION AGENCY - USEPA, August. National Water Quality Inventory 2000 Report. EPA-841-R-02-001, 2002.

87. VAN HAANDEL, Adrianus Cornelius; MARAIS, Gerrit. O comportamento do sistema de lodo ativado: teoria e aplicações para projetos e operação. In: O comportamento do sistema de lodo ativado: Teoria e Aplicações para Projetos e Operação. epgraf, 1999.

88. VAN HAANDEL, Adrianus. Nutrientes de esgoto sanitário: utilização e remoção. Capitulo 6. Francisco Suetônio Bastos Mota e Marcos Von Sperling (coordenadores). Rio de Janeiro: ABES, 2009.

89. VAN LOOSDRECHT, M.C.M.; JETTEN, M.S.M. Microbiological conversions in nitrogen removal. Water Science and Technology, v. 38, n. 1, p. 1-7, 1998.

90. VARNIER, Claudia. O Efeito do Nitrogênio proveniente de Sistemas de Saneamento "in situ" na Qualidade das Águas Subterrâneas em Aquíferos Livres e Rasos. (Dissertação de mestrado). Programa de Pós-Graduação em Recursos Minerais e Hidrogeologia. Instituto de Geociências. Universidade de São Paulo, 2001.

91. VARNIER, Claudia; IRITANI, Mara Akie; VIOTTI, Maurício; ODA, Geraldo Hideo; FERREIRA, Luciana Martin Rodrigues. Nitrato nas águas subterrâneas do sistema aquífero Bauru, área urbana do município de Marília (SP). Revista Instituto Geológico, São Paulo, v. 31, n. 1/22, p. 1-21, 2010.

92. VARNIER, Claudia. Isótopos de Nitrogênio: Conceitos e Aplicações em Hidrogeologia (aula). GSA 5856 - Estudos Isotópicos Aplicados a Questões Ambientais e Hidrogeológicas. Núcleo de Hidrogeologia. Instituto Geológico (IG/SMA). Abril/2015.

93. VIRDIS, B.; RABAEY, K.; YUAN, Z.; KELLER, J.. Microbial fuel cells for simultaneous carbon and nitrogen removal. Water research, v. 42, n. 12, p. 3013-3024, 2008.

94. VIRDIS, B.; RABAEY, K.; YUAN, Z.; ROZENDAL, R. A.; KELLER, J. Electron fluxes in a microbial fuel cell performing carbon and nitrogen removal. Environmental science \& technology, 43(13), 5144-5149, 2009.

95. VIRDIS, B.; RABAEY, K.; ROZENDAL, R.; YUAN, Z.; KELLER, J.. Simultaneous nitrification, denitrification and carbon removal in microbial fuel cells. Water Research 44 (9), 2970-2980. 2010.

96. WANG, Heming; REN, Zhiyong Jason. A comprehensive review of microbial electrochemical systems as a platform technology. Biotechnology advances, v. $31, \mathrm{n}$. 8, p. 1796-1807, 2013.

97. WARD, Mary H.; DEKOK, Theo M.; LEVALLOIS, Patrick; BRENDER, Jean; GULIS, Gabriel; NOLAN, Bernard T.; VANDERSLICE, James. Workgroup report: Drinkingwater nitrate and health-recent findings and research needs. Environmental health perspectives, p. 1607-1614, 2005.

98. WILHELM, S.; SCHIFF, S.; CHERRY, J.. Biogeochemical evolution of domestic waste in septic systems: Conceptual Model Groundwater. v. 32, n. 6, p. 90S-g16, 1994.

99. ZHANG, Yifeng; ANGELIDAKI, Irini. A new method for in situ nitrate removal from groundwater using submerged microbial desalination-denitrification cell (SMDDC). Water Research, v. 47, n. 5, p. 1827-1836, 2013.

100. ZHAO, Yingxin; FENG, Chuanping; WANG, Qinghong; YANG, Yingnan; ZHANG, Zhenya; SUGIURA, Norio. Nitrate removal from groundwater by cooperating heterotrophic with autotrophic denitrification in a biofilm-electrode reactor. Journal of hazardous materials, v. 192, n. 3, p. 1033-1039, 2011. 
ANEXO I - Especificações Técnicas da Membrana de Troca iônica 
CMI-7000 Cation Exchange Membranes Technical Specifications

\begin{tabular}{|c|c|}
\hline \multirow{2}{*}{ Technical Specification } & CMI-7000S \\
\hline & Single Sheet \\
\hline Functionality & Strong Acid Cation Exchange Membrane \\
\hline Polymer Structure & Gel polystyrene cross linked with divinylbenzene \\
\hline Functional Group & Sulphonic Acid \\
\hline Ionic Form as Shipped & Sodium \\
\hline Color & Brown \\
\hline $\begin{array}{ll}\text { Standard Size } & : \text { US } \\
& : \text { Metric }\end{array}$ & $\begin{array}{l}48 \mathrm{in} \times 120 \mathrm{in} \\
1.2 \mathrm{~m} \times 3.1 \mathrm{~m}\end{array}$ \\
\hline $\begin{array}{r}\text { Standard Thickness (mils) } \\
(\mathbf{m m})\end{array}$ & $\begin{array}{c}18 \pm 1 \\
0.45 \pm 0.025\end{array}$ \\
\hline $\begin{array}{l}\text { Electrical Resistance (Ohm. } \mathrm{cm}^{2} \text { ) } \\
0.5 \mathrm{~mol} / \mathrm{L} \mathrm{NaCl}\end{array}$ & $<30$ \\
\hline Maximum Current Density (Ampere/m²) & $<500$ \\
\hline $\begin{array}{l}\text { Permselectivity (\%) } \\
0.1 \mathrm{~mol} \mathrm{KCl} / \mathrm{kg} / 0.5 \mathrm{~mol} \mathrm{KCl} / \mathrm{kg}\end{array}$ & 94 \\
\hline Total Exchange Capacity (meq/g) & $1.6 \pm 0.1$ \\
\hline $\begin{array}{l}\text { Water Permeability } \\
\left(\mathrm{ml} / \mathrm{hr} / \mathrm{ft}^{2}\right) @ 5 \mathrm{psi}\end{array}$ & $<3$ \\
\hline Mullen Burst Test strength (psi) & $>80$ \\
\hline Thermal Stability $\left({ }^{\circ} \mathrm{C}\right)$ & 90 \\
\hline Chemical Stability Range (pH) & $1-10$ \\
\hline Preconditioning Procedure & $\begin{array}{l}\text { Immerse the membrane in either the application } \\
\text { solution or a } 5 \% \mathrm{NaCl} \text { solution for } 12 \text { hours to allow } \\
\text { for membrane hydration and expansion. }\end{array}$ \\
\hline Storage & $\begin{array}{l}\text { Store at room temperature and low humidity in } \\
\text { sealed air tight container. Storage period not to } \\
\text { exceed one year. }\end{array}$ \\
\hline
\end{tabular}

All information described in this bulletin is based upon tests and data believed to be reliable. It is the user's responsibility to determine performance and suitability of the products. No guarantee, expressed or implied, is made by Membranes International Inc., nor does Membranes International Inc. assume any liability for patent infringement arising from the use of these products. 
ANEXO II - Resultados das análises laboratoriais 


\begin{tabular}{|c|c|c|c|c|c|c|c|c|c|c|c|c|c|c|c|}
\hline \multicolumn{5}{|c|}{ Analises } & \multirow{2}{*}{\begin{tabular}{|l|} 
L/dia \\
Taxa de aplicação \\
\end{tabular}} & \multirow{2}{*}{\begin{tabular}{|l|}
$\mathrm{mg} / \mathrm{L}$ \\
Cloreto
\end{tabular}} & \multirow{2}{*}{$\frac{\mathrm{mg} / \mathrm{L}}{\text { Nitrito-N }}$} & \multirow{2}{*}{$\begin{array}{l}\mathrm{mg} / \mathrm{L} \\
\text { Nitrato-N }\end{array}$} & \multirow{2}{*}{\begin{tabular}{|l|}
$\mathrm{mg} / \mathrm{L}$ \\
Fosfato-P
\end{tabular}} & \multirow{2}{*}{$\begin{array}{l}\mathrm{mg} / \mathrm{L} \\
\text { Sulfato }\end{array}$} & \multirow{2}{*}{$\begin{array}{l}\mu \mathrm{S} / \mathrm{cm} \\
\text { Condutividade }\end{array}$} & \multirow{2}{*}{\begin{tabular}{|l}
${ }^{\circ} \mathrm{C}$ \\
temperatura
\end{tabular}} & \multirow{2}{*}{ pH } & \multirow{2}{*}{\begin{tabular}{|l|} 
mg CaCO3/L \\
Alcalinidade
\end{tabular}} & \multirow{2}{*}{\begin{tabular}{|l}
$\mathrm{mA}$ \\
Corrente
\end{tabular}} \\
\hline & Teste & Hora & Data Coleta & Tipo & & & & & & & & & & & \\
\hline 1 & $\# 1$ & - & $21 / 09 / 2016$ & Branco & 1,44 & 0,0000 & 0,0000 & 0,0000 & 0,0000 & 0,0000 & - & - & - & - & - \\
\hline 2 & $\# 1$ & - & 21/09/2016 & Anodo entrada & 1,44 & 7,8404 & 0,0000 & 0,0000 & 117,6276 & 0,0000 & 1115 & 22,7 & 7,94 & - & - \\
\hline 3 & $\# 1$ & - & 21/09/2016 & Catodo entrada & 1,44 & 2,1354 & 0,0000 & 15,7898 & 126,9002 & 5,3631 & 1178 & 22,6 & 7,73 & - & - \\
\hline 4 & $\# 1$ & - & $21 / 09 / 2016$ & Coleta & 1,44 & 7,5205 & 0,0000 & 0,0000 & 75,5696 & 3,7839 & 1165 & 22,6 & 7,6 & - & - \\
\hline 5 & $\# 1$ & - & $23 / 09 / 2016$ & Coleta & 1,44 & 12,0083 & 0,1604 & 0,0000 & 60,532 & 4,1497 & 1126 & 22,5 & 7,38 & - & - \\
\hline 6 & $\# 1$ & - & 26/09/2016 & Coleta & 1,44 & 8,0086 & 0,0000 & 0,0000 & 58,4579 & 1,911 & 1118 & 22,3 & 7,73 & - & - \\
\hline 7 & $\# 1$ & - & $27 / 09 / 2016$ & Coleta & 1,44 & 7,4325 & 0,0000 & 0,0000 & 62,4916 & 4,0723 & 1109 & 22,5 & 7,92 & - & - \\
\hline 8 & $\# 1$ & - & $29 / 09 / 2016$ & Coleta & 1,44 & 5,1684 & 0,0000 & 0,3788 & 103,0006 & 7,2263 & 1127 & 22,6 & 8,2 & - & - \\
\hline 9 & $\# 1$ & - & $01 / 10 / 2016$ & Coleta & 1,44 & 4,0017 & 0,1558 & 0,0000 & 110,3042 & 5,2004 & 1152 & 22,5 & 7,83 & - & - \\
\hline 10 & $\# 1$ & - & 08/10/2016 & Branco & 1,44 & 0,0000 & 0,0000 & 0,0000 & 0,0000 & 1,8533 & - & 22,5 & 7,58 & - & - \\
\hline 11 & $\# 1$ & - & 08/10/2016 & Padrão & 1,44 & 3,5916 & 0,0000 & 2,1016 & 5,7495 & 0,0000 & - & 22,6 & 7,71 & - & - \\
\hline 12 & $\# 1$ & - & 03/10/2016 & Coleta & 1,44 & 5,8209 & 0,0000 & 0 & 97,8335 & 4,2297 & - & 22,5 & 7,66 & - & - \\
\hline 13 & $\# 1$ & - & $04 / 10 / 2016$ & Coleta & 1,44 & 6,4669 & 0,0000 & 1,4984 & 86,533 & 5,3323 & - & 22,5 & 7,71 & - & - \\
\hline 14 & $\# 1$ & - & 05/10/2016 & Coleta & 1,44 & 6,4503 & 0,1395 & 2,3391 & 84,8184 & 5,8487 & - & 22,7 & 7,78 & - & - \\
\hline 15 & $\# 1$ & - & 06/10/2016 & Coleta & 1,44 & 5,9227 & 0,1422 & 1,0177 & 91,6011 & 5,2632 & - & 22,7 & 7,74 & - & - \\
\hline 16 & $\# 1$ & - & $07 / 10 / 2016$ & Coleta & 1,44 & 4,004 & 0,2563 & 2,9113 & 109,4405 & 6,7562 & - & 22,7 & 7,83 & - & - \\
\hline 17 & $\# 1$ & 10:00 & $08 / 10 / 2016$ & Coleta & 1,44 & 3,6637 & 0,3119 & 3,4653 & 112,1759 & 7,238 & - & 22,6 & 7,73 & - & - \\
\hline 18 & $\# 1$ & $14: 00$ & 08/10/2016 & Coleta & 1,44 & 3,0103 & 0,4192 & 4,4659 & 116,3086 & 8,1608 & - & 22,6 & 7,59 & - & - \\
\hline 19 & $\# 1$ & - & 08/10/2016 & Anodo entrada & 1,44 & 6,6875 & 0,0000 & 0,0000 & 83,4261 & 3,9994 & - & 22,5 & 7,48 & - & - \\
\hline 20 & $\# 1$ & - & 08/10/2016 & Catodo entrada & 1,44 & 1,7368 & 0,0000 & 10,1838 & 54,6089 & 5,1447 & - & 22,3 & 7,71 & - & - \\
\hline 21 & $\# 1$ & - & $22 / 10 / 2016$ & Branco & 1,44 & 0,0000 & 0,0000 & 0,0000 & 0,0000 & 0,0000 & - & 22,5 & 7,58 & - & - \\
\hline 22 & $\# 1$ & - & $22 / 10 / 2016$ & Padrão & 1,44 & 3,7835 & 0,0000 & 2,0617 & 5,3182 & 0,0000 & - & 22,6 & 7,71 & - & - \\
\hline 23 & $\# 1$ & - & $17 / 10 / 2016$ & Coleta & 1,44 & 0,0000 & 0,2991 & 1,7905 & 113,0844 & 5,4697 & - & 22,5 & 7,66 & - & - \\
\hline 24 & $\# 1$ & - & $17 / 10 / 2016$ & Coleta & 1,44 & 3,7898 & 0,0000 & 0 & 107,5459 & 3,1852 & - & 22,5 & 7,71 & - & - \\
\hline 25 & $\# 1$ & - & $18 / 10 / 2016$ & Coleta & 1,44 & 0,0000 & 0,1459 & 0,3282 & 0,0000 & 4,6058 & - & 22,7 & 7,78 & - & - \\
\hline 26 & $\# 1$ & - & $19 / 10 / 2016$ & Coleta & 1,44 & 3,3016 & 0,5865 & 1,0451 & 103,726 & 4,0427 & - & 22,7 & 7,74 & - & - \\
\hline 27 & $\# 1$ & - & $20 / 10 / 2016$ & Coleta & 1,44 & 4,4254 & 0,1512 & 0,9114 & 96,9828 & 3,3516 & - & 22,7 & 7,83 & - & - \\
\hline 28 & $\# 1$ & - & $21 / 10 / 2016$ & Coleta & 1,44 & 4,3213 & 0,1381 & 0,3091 & 114,7444 & 3,0373 & - & 22,6 & 7,73 & - & - \\
\hline 29 & $\# 1$ & - & $21 / 10 / 2016$ & Coleta & 1,44 & 3,9772 & 0,152 & 0,3279 & 132,3073 & 4,1739 & - & \begin{tabular}{|l|}
22,6 \\
\end{tabular} & 7,59 & - & - \\
\hline
\end{tabular}




\begin{tabular}{|c|c|c|c|c|c|c|c|c|c|c|c|c|c|c|c|}
\hline \multicolumn{5}{|c|}{ Analises } & \multirow{2}{*}{\begin{tabular}{|l|} 
L/dia \\
Taxa de aplicação \\
\end{tabular}} & \multirow{2}{*}{\begin{tabular}{|l|}
$\mathrm{mg} / \mathrm{L}$ \\
Cloreto \\
\end{tabular}} & \multirow{2}{*}{\begin{tabular}{|l|}
$\mathrm{mg} / \mathrm{L}$ \\
Nitrito-N \\
\end{tabular}} & \multirow{2}{*}{\begin{tabular}{|l|}
$\mathrm{mg} / \mathrm{L}$ \\
Nitrato-N \\
\end{tabular}} & \multirow{2}{*}{\begin{tabular}{|l|}
$\mathrm{mg} / \mathrm{L}$ \\
Fosfato-P
\end{tabular}} & \multirow{2}{*}{\begin{tabular}{|l|}
$\mathrm{mg} / \mathrm{L}$ \\
Sulfato \\
\end{tabular}} & \multirow{2}{*}{$\begin{array}{l}\mu \mathrm{S} / \mathrm{cm} \\
\text { Condutividade }\end{array}$} & \multirow{2}{*}{\begin{tabular}{|l|}
${ }^{\circ} \mathrm{C}$ \\
temperatura \\
\end{tabular}} & \multirow{2}{*}{$\begin{array}{l}- \\
\mathrm{pH}\end{array}$} & \multirow{2}{*}{\begin{tabular}{|l|}
$\mathrm{mg} \mathrm{CaCO} / \mathrm{L}$ \\
Alcalinidade
\end{tabular}} & \multirow{2}{*}{\begin{tabular}{|l|}
$\mathrm{mA}$ \\
Corrente
\end{tabular}} \\
\hline & Teste & Hora & Data Coleta & Tipo & & & & & & & & & & & \\
\hline 30 & $\# 2$ & - & 05/11/2016 & Branco & 1,44 & 1,6148 & 0,0000 & 0,4088 & 0,0000 & 0,0000 & - & 22,5 & 7,48 & - & - \\
\hline 31 & $\# 2$ & - & $05 / 11 / 2016$ & Branco & 1,44 & 0,5533 & 0,0000 & 0,0000 & 0,0000 & 0,0000 & - & 22,3 & 7,71 & - & - \\
\hline 32 & $\# 2$ & - & $31 / 10 / 2016$ & Coleta & 1,44 & 12,6376 & 0,0000 & 0 & 97,2794 & 3,174 & - & 22,5 & 7,58 & - & - \\
\hline 33 & \# 2 & - & 01/11/2016 & Coleta & 1,44 & 12,3222 & 0,8713 & 0,3377 & 95,2548 & 2,6913 & - & 22,6 & 7,71 & - & - \\
\hline 34 & $\# 2$ & - & $02 / 11 / 2016$ & Coleta & 1,44 & 10,6238 & 0,4113 & 0,4496 & 101,7403 & 3,5265 & - & 22,5 & 7,66 & - & - \\
\hline 35 & $\# 2$ & - & $03 / 11 / 2016$ & Coleta & 1,44 & 10,2984 & 0,1868 & 0,3819 & 101,2917 & 2,8706 & - & 22,5 & 7,71 & - & - \\
\hline 36 & $\# 2$ & - & $04 / 11 / 2016$ & Coleta & 1,44 & 10,5232 & 0,0000 & 0 & 100,6248 & 2,731 & - & 22,7 & 7,78 & - & - \\
\hline 37 & $\# 2$ & - & $05 / 11 / 2016$ & Coleta & 1,44 & 10,3091 & 0,4673 & 1,3747 & 108,1645 & 3,0039 & - & 22,7 & 7,74 & - & - \\
\hline 38 & $\# 2$ & - & 05/11/2016 & Catodo entrada & 1,44 & 10,7222 & 0,1435 & 10,7445 & 142,147 & 3,6929 & - & 22,7 & 7,83 & - & - \\
\hline 39 & $\# 2$ & - & 05/11/2016 & Anodo entrada & 1,44 & 10,1279 & 0,0000 & 0,0000 & 76,2303 & 3,7856 & - & 22,6 & 7,73 & - & - \\
\hline 40 & $\# 2$ & - & $22 / 11 / 2016$ & Branco & 1,44 & 0,0000 & 0,0000 & 0,0000 & 0,0000 & 0,0000 & - & 22,6 & 7,59 & - & - \\
\hline 41 & $\# 2$ & - & 22/11/2016 & Catodo entrada & 1,44 & 11,8527 & 0,5335 & 12,8831 & 72,8659 & 3,9939 & - & 22,5 & 7,48 & - & - \\
\hline 42 & \# 2 & - & 22/11/2016 & Coleta & 1,44 & 11,3286 & 0,2559 & 1,1826 & 85,6608 & 4,7483 & - & 22,3 & 7,71 & - & - \\
\hline 43 & $\# 2$ & - & $22 / 11 / 2016$ & Coleta & 1,44 & 10,2918 & 0,2273 & 1,2885 & 87,3697 & 4,2959 & - & 22,5 & 7,58 & - & - \\
\hline 44 & $\# 2$ & - & $30 / 11 / 2016$ & Branco & 1,44 & 0,0000 & 0,6012 & 0,0000 & 6,8216 & 0,0000 & - & 22,6 & 7,71 & - & - \\
\hline 45 & $\# 2$ & - & $30 / 11 / 2016$ & Padrão & 1,44 & 12,997 & 13,1054 & 8,8025 & 21,0209 & 1,8684 & - & 22,5 & 7,66 & - & - \\
\hline 46 & $\# 2$ & - & $30 / 11 / 2016$ & Coleta & 1,44 & 12,1829 & 0,0000 & 3,7891 & 94,3188 & 4,6787 & - & 22,5 & 7,71 & - & - \\
\hline 47 & $\# 2$ & - & $30 / 11 / 2016$ & Coleta & 1,44 & 12,698 & 0,8034 & 4,2688 & 58,0228 & 6,4807 & - & 22,7 & 7,78 & - & - \\
\hline 48 & $\# 2$ & - & $30 / 11 / 2016$ & Catodo entrada & 1,44 & 10,7735 & 0,1187 & 10,7049 & 49,2413 & 3,9446 & - & 22,7 & 7,74 & - & - \\
\hline 49 & \# 3 & - & $27 / 01 / 2017$ & Padrão & 1,44 & 1,0271 & 0,7267 & 0,6558 & 1,279 & 5,3294 & - & 22,7 & 7,83 & - & - \\
\hline 50 & \#3 & - & $27 / 01 / 2017$ & Anodo entrada & 1,44 & 10,5204 & 0,281 & 0,3404 & 53,759 & 7,2696 & - & 22,6 & 7,73 & - & - \\
\hline 51 & $\# 3$ & - & $27 / 01 / 2017$ & Catodo entrada & 1,44 & 5,8246 & 0,0000 & 12,5856 & 24,6318 & 6,4081 & - & 22,6 & 7,59 & - & - \\
\hline 52 & $\# 3$ & - & $27 / 01 / 2017$ & Coleta & 1,44 & 9,309 & 0,1326 & 1,2288 & 46,4749 & 6,7599 & - & 22,5 & 7,48 & - & 0,01 \\
\hline 53 & $\# 3$ & - & $27 / 01 / 2017$ & Coleta & 1,44 & 10,9004 & 0,1826 & 1,2884 & 50,4822 & 13,6143 & - & 22,3 & 7,71 & - & 0,01 \\
\hline 54 & $\# 4$ & - & $20 / 05 / 2017$ & Coleta & 1,44 & 11,0407 & 0,0000 & 0,0000 & 41,3996 & 5,7324 & 1523 & 22,5 & 7,58 & - & 0,00 \\
\hline 55 & $\# 4$ & - & $20 / 05 / 2017$ & Coleta & 1,44 & 11,1183 & 0,0000 & 0,0000 & 100,1861 & 5,6543 & 1175 & 22,6 & 7,71 & - & 0,01 \\
\hline 56 & $\# 4$ & - & $20 / 05 / 2017$ & Coleta & 1,44 & 9,5593 & 0,595 & 5,9817 & 99,2528 & 5,6325 & 1161 & 22,5 & 7,66 & - & 0,01 \\
\hline 57 & $\# 4$ & - & $19 / 05 / 2017$ & Coleta & 1,44 & 8,8454 & 0,179 & 1,5455 & 51,6968 & 4,0523 & 1189 & 22,5 & 7,71 & - & 0,01 \\
\hline 58 & \# 4 & - & $23 / 05 / 2017$ & Branco & 1,44 & 0,3355 & 0,0000 & 0,5195 & 0,0000 & 0,0000 & 1192 & 22,7 & 7,78 & - & - \\
\hline
\end{tabular}




\begin{tabular}{|c|c|c|c|c|c|c|c|c|c|c|c|c|c|c|c|}
\hline \multicolumn{5}{|c|}{ Analises } & \multirow{2}{*}{\begin{tabular}{|l|} 
L/dia \\
Taxa de aplicação \\
\end{tabular}} & \multirow{2}{*}{\begin{tabular}{|l|}
$\mathrm{mg} / \mathrm{L}$ \\
Cloreto \\
\end{tabular}} & \multirow{2}{*}{\begin{tabular}{|l|}
$\mathrm{mg} / \mathrm{L}$ \\
Nitrito-N \\
\end{tabular}} & \multirow{2}{*}{\begin{tabular}{|l|}
$\mathrm{mg} / \mathrm{L}$ \\
Nitrato-N \\
\end{tabular}} & \multirow{2}{*}{\begin{tabular}{|l|}
$\mathrm{mg} / \mathrm{L}$ \\
Fosfato-P
\end{tabular}} & \multirow{2}{*}{\begin{tabular}{|l|}
$\mathrm{mg} / \mathrm{L}$ \\
Sulfato \\
\end{tabular}} & \multirow{2}{*}{$\begin{array}{l}\mu \mathrm{S} / \mathrm{cm} \\
\text { Condutividade }\end{array}$} & \multirow{2}{*}{\begin{tabular}{|l|}
${ }^{\circ} \mathrm{C}$ \\
temperatura \\
\end{tabular}} & \multirow{2}{*}{$\begin{array}{l}- \\
\mathrm{pH}\end{array}$} & \multirow{2}{*}{\begin{tabular}{|l|}
$\mathrm{mg} \mathrm{CaCO} / \mathrm{L}$ \\
Alcalinidade
\end{tabular}} & \multirow{2}{*}{\begin{tabular}{|l|}
$\mathrm{mA}$ \\
Corrente
\end{tabular}} \\
\hline & Teste & Hora & Data Coleta & Tipo & & & & & & & & & & & \\
\hline 59 & $\# 4$ & - & $23 / 05 / 2017$ & Catodo entrada & 1,44 & 7,3033 & 0,0000 & 0,0000 & 54,4399 & 0,0000 & 1200 & 22,7 & 7,74 & - & - \\
\hline 60 & $\# 4$ & - & $23 / 05 / 2017$ & Coleta & 1,44 & 8,7997 & 0,0000 & 0 & 86,2978 & 3,3442 & 1195 & 22,7 & 7,83 & - & 0,01 \\
\hline 61 & \# 4 & - & $23 / 05 / 2017$ & Coleta & 1,44 & 8,9995 & 0,0000 & 0 & 48,3743 & 4,716 & 1179 & 22,6 & 7,73 & - & 0,01 \\
\hline 62 & \# 4 & - & $20 / 05 / 2017$ & Coleta & 1,44 & 10,6733 & 0,0000 & 0 & 43,5699 & 5,7315 & 1057 & 22,6 & 7,59 & - & 0,00 \\
\hline 63 & \# 4 & - & 20/05/2017 & Coleta & 1,44 & 11,12 & 0,0000 & 0 & 42,457 & 5,6065 & 1053 & 22,5 & 7,48 & - & 0,01 \\
\hline 64 & $\# 4$ & - & $20 / 05 / 2017$ & Catodo entrada & 1,44 & 6,76 & 0,0000 & 12,9857 & 92,8672 & 7,2576 & 1143 & 22,3 & 7,71 & - & - \\
\hline 65 & $\# 4$ & - & $20 / 05 / 2017$ & Coleta & 1,44 & 9,6569 & 0,6127 & 5,8873 & 104,7277 & 5,5568 & - & - & - & - & - \\
\hline 66 & $\# 4$ & - & $23 / 05 / 2017$ & Coleta & 1,44 & - & - & 0 & - & - & - & - & - & - & - \\
\hline 67 & $\# 4$ & - & $20 / 05 / 2017$ & Catodo entrada & 1,44 & 5,6581 & 0,0000 & 13,6414 & 36,5582 & 6,0924 & - & - & - & - & - \\
\hline 68 & $\# 4$ & - & $20 / 05 / 2017$ & Catodo entrada & 1,44 & 7,1358 & 0,0000 & 15,0919 & 55,6804 & 9,6124 & - & - & - & - & - \\
\hline 69 & $\# 4$ & - & $20 / 05 / 2017$ & Catodo entrada & 1,44 & 6,3871 & 0,0000 & 20,8487 & 51,3648 & 8,4512 & - & - & - & - & - \\
\hline 70 & \# 4 & - & $24 / 05 / 2017$ & Catodo entrada & 1,44 & 7,4874 & 0,0000 & 16,6705 & 131,4102 & 8,0508 & 1523 & 22,5 & 7,58 & 256,03 & - \\
\hline 71 & \# 4 & $10: 30$ & 24/05/2017 & Coleta & 1,44 & 8,5261 & 0,0000 & 0 & 88,918 & 4,7077 & 1175 & 22,6 & 7,71 & 252,00 & 0,01 \\
\hline 72 & $\# 4$ & $11: 30$ & $24 / 05 / 2017$ & Coleta & 1,44 & 8,4479 & 0,0000 & 0 & 85,4953 & 4,4976 & 1161 & 22,5 & 7,66 & 253,58 & 0,02 \\
\hline 73 & $\# 4$ & $12: 30$ & $24 / 05 / 2017$ & Coleta & 1,44 & 8,2924 & 0,204 & 0 & 88,3823 & 4,7605 & 1189 & 22,5 & 7,71 & 257,60 & 0,01 \\
\hline 74 & $\# 4$ & 13:30 & $24 / 05 / 2017$ & Coleta & 1,44 & 9,0424 & 0,0000 & 0 & 87,7813 & 5,0196 & 1192 & 22,7 & 7,78 & 240,00 & 0,01 \\
\hline 75 & $\# 4$ & $14: 30$ & $24 / 05 / 2017$ & Coleta & 1,44 & 8,8567 & 0,0000 & 0 & 89,147 & 5,3049 & 1200 & 22,7 & 7,74 & 257,25 & 0,01 \\
\hline 76 & $\# 4$ & $15: 30$ & $24 / 05 / 2017$ & Coleta & 1,44 & 8,5451 & 0,0000 & 0 & 89,4729 & 5,5878 & 1195 & 22,7 & 7,83 & 247,73 & 0,01 \\
\hline 77 & $\# 4$ & $16: 30$ & $24 / 05 / 2017$ & Coleta & 1,44 & 8,9517 & 0,0000 & 0 & 81,7779 & 4,8162 & 1179 & 22,6 & 7,73 & 265,85 & 0,02 \\
\hline 78 & $\# 4$ & 18:30 & $24 / 05 / 2017$ & Coleta & 1,44 & - & - & 0 & - & - & 1057 & 22,6 & 7,59 & 221,76 & 0,01 \\
\hline 79 & $\# 4$ & 19:30 & $24 / 05 / 2017$ & Coleta & 1,44 & - & - & 0 & - & - & 1053 & 22,5 & 7,48 & 211,35 & 0,01 \\
\hline 80 & $\# 4$ & $20: 30$ & $24 / 05 / 2017$ & Coleta & 1,44 & - & - & 0 & - & - & 1143 & 22,3 & 7,71 & 234,18 & 0,01 \\
\hline 81 & $\# 4$ & - & $25 / 05 / 2017$ & Branco & 1,44 & 0,3874 & 0,0000 & 0,0000 & 0,0000 & 0,0000 & - & - & - & - & - \\
\hline 82 & $\# 4$ & - & $25 / 05 / 2017$ & Catodo entrada & 1,44 & 7,6401 & 0,0000 & 16,7739 & 133,4078 & 5,2198 & 1523 & 22,5 & 7,58 & 256,03 & - \\
\hline 83 & $\# 4$ & - & $25 / 05 / 2017$ & Anodo entrada & 1,44 & 9,2556 & 0,0459 & 0,0000 & 57,6653 & 6,9952 & 910 & 22,5 & 7,68 & 187,49 & - \\
\hline 84 & $\# 4$ & - & $25 / 05 / 2017$ & Anodo reator & 1,44 & 9,417 & 0,0000 & 0,0000 & 59,5632 & 5,3053 & 816 & 22,7 & 7,06 & 194,40 & - \\
\hline 85 & $\# 4$ & - & $25 / 05 / 2017$ & Catodo reator & 1,44 & - & - & - & - & - & 1269 & 22,6 & 7,59 & 279,45 & - \\
\hline 86 & $\# 4$ & - & $25 / 05 / 2017$ & Coleta & 1,44 & 8,5711 & 0,0000 & 0 & 87,9454 & 3,3529 & - & - & - & - & 0,02 \\
\hline 87 & \# 5 & - & $27 / 05 / 2017$ & Branco & 2,88 & 0,4107 & 0,0000 & 0,0000 & 0,0000 & 0,0000 & - & - & - & - & - \\
\hline
\end{tabular}




\begin{tabular}{|c|c|c|c|c|c|c|c|c|c|c|c|c|c|c|c|}
\hline \multicolumn{5}{|c|}{ Analises } & \multirow{2}{*}{\begin{tabular}{|l|} 
L/dia \\
Taxa de aplicação
\end{tabular}} & \multirow{2}{*}{\begin{tabular}{|l|}
$\mathrm{mg} / \mathrm{L}$ \\
Cloreto \\
\end{tabular}} & \multirow{2}{*}{\begin{tabular}{|l|}
$\mathrm{mg} / \mathrm{L}$ \\
Nitrito-N \\
\end{tabular}} & \multirow{2}{*}{\begin{tabular}{|l|}
$\mathrm{mg} / \mathrm{L}$ \\
Nitrato-N \\
\end{tabular}} & \multirow{2}{*}{\begin{tabular}{|l|}
$\mathrm{mg} / \mathrm{L}$ \\
Fosfato-P
\end{tabular}} & \multirow{2}{*}{\begin{tabular}{|l|}
$\mathrm{mg} / \mathrm{L}$ \\
Sulfato \\
\end{tabular}} & \multirow{2}{*}{$\begin{array}{l}\mu \mathrm{S} / \mathrm{cm} \\
\text { Condutividade }\end{array}$} & \multirow{2}{*}{\begin{tabular}{|l|}
${ }^{\circ} \mathrm{C}$ \\
temperatura \\
\end{tabular}} & \multirow{2}{*}{$\begin{array}{l}- \\
\mathrm{pH}\end{array}$} & \multirow{2}{*}{\begin{tabular}{|l|}
$\mathrm{mg} \mathrm{CaCO} / \mathrm{L}$ \\
Alcalinidade
\end{tabular}} & \multirow{2}{*}{\begin{tabular}{|l|}
$\mathrm{mA}$ \\
Corrente
\end{tabular}} \\
\hline & Teste & Hora & Data Coleta & Tipo & & & & & & & & & & & \\
\hline 88 & $\# 5$ & - & 27/05/2017 & Catodo entrada & 2,88 & 7,5516 & 0,0545 & 12,8539 & 133,0777 & 0,9864 & 1530 & 24,4 & 7,3 & 245,63 & - \\
\hline 89 & $\# 5$ & - & $27 / 05 / 2017$ & Coleta & 2,88 & 8,3391 & 1,1234 & 3,1836 & 93,477 & 7,5031 & - & - & - & - & - \\
\hline 90 & $\# 5$ & 09:45 & $27 / 05 / 2017$ & Coleta & 2,88 & 8,0496 & 1,3484 & 2,8486 & 91,987 & 7,5105 & 1195 & 22,5 & 7,3 & 229,82 & 0,02 \\
\hline 91 & $\# 5$ & - & $27 / 05 / 2017$ & Catodo entrada & 2,88 & 6,5466 & 0,0000 & 23,1294 & 50,2963 & 10,3515 & - & - & - & - & - \\
\hline 92 & $\# 5$ & - & 27/05/2017 & Catodo entrada & 2,88 & 7,3032 & 0,0513 & 16,7784 & 51,0042 & 9,603 & 1530 & 24,4 & 7,3 & 245,63 & - \\
\hline 93 & $\# 5$ & $10: 45$ & $27 / 05 / 2017$ & Coleta & 2,88 & 8,1539 & 1,4039 & 1,0306 & 89,8754 & 7,1203 & 1161 & 24 & 7,3 & 235,77 & 0,01 \\
\hline 94 & $\# 5$ & $11: 45$ & $27 / 05 / 2017$ & Coleta & 2,88 & 8,2167 & 0,4619 & 0,6149 & 89,3876 & 6,4946 & 1161 & 24,2 & 7,28 & 246,11 & 0,02 \\
\hline 95 & $\# 5$ & $12: 45$ & $27 / 05 / 2017$ & Coleta & 2,88 & 8,0777 & 1,2563 & 1,2459 & 94,6598 & 7,1402 & 1217 & 24 & 7,35 & 247,03 & 0,01 \\
\hline 96 & $\# 5$ & $12: 45$ & $27 / 05 / 2017$ & Anodo reator & 2,88 & 9,3655 & 0,1051 & 0,0000 & 68,47 & 2,5328 & 882 & 24,3 & 6,84 & 166,40 & - \\
\hline 97 & $\# 5$ & $13: 45$ & $27 / 05 / 2017$ & Coleta & 2,88 & 8,2025 & 0,6344 & 0,5138 & 91,9641 & 6,0834 & 1194 & 24,1 & 7,43 & 252,00 & 0,01 \\
\hline 98 & $\# 5$ & $14: 45$ & $27 / 05 / 2017$ & Coleta & 2,88 & 8,0488 & 0,3872 & 0,4625 & 91,1624 & 4,8568 & 1189 & 24,3 & 7,47 & 248,12 & 0,02 \\
\hline 99 & \# 5 & 15:45 & $27 / 05 / 2017$ & Coleta & 2,88 & 8,2829 & 0,15 & 0,2765 & 89,1994 & 5,7407 & 1194 & 24,1 & 7,66 & 255,36 & 0,02 \\
\hline 100 & \# 5 & $16: 45$ & 27/05/2017 & Coleta & 2,88 & 8,1427 & 0,1682 & 0,3045 & 94,329 & 5,2127 & 1201 & 24,1 & 7,63 & 252,00 & 0,02 \\
\hline 101 & $\# 5$ & $16: 45$ & $27 / 05 / 2017$ & Anodo reator & 2,88 & 9,2503 & 0,0698 & 0,0000 & 67,5653 & 1,8187 & 880 & 24,4 & 6,7 & 163,65 & - \\
\hline 102 & $\# 5$ & $16: 45$ & $27 / 05 / 2017$ & Catodo reator & 2,88 & 7,8928 & 3,6724 & 5,4692 & 112,6967 & 8,2968 & 1276 & 24,3 & 7,31 & 241,92 & - \\
\hline 103 & $\# 5$ & $16: 45$ & $27 / 05 / 2017$ & Catodo entrada & 2,88 & 7,4789 & 0,2665 & 17,0194 & 48,1858 & 9,7453 & 1530 & 24,4 & 7,3 & 245,63 & - \\
\hline 104 & $\# 5$ & - & $27 / 05 / 2017$ & Anodo entrada & 2,88 & - & - & - & - & - & 907 & 24,1 & 7,24 & 174,11 & - \\
\hline 105 & $\# 5$ & $17: 45$ & $27 / 05 / 2017$ & Coleta & 2,88 & 8,328 & 0,0706 & 0 & 94,9967 & 6,0124 & 1218 & 23,6 & 7,65 & 252,00 & 0,02 \\
\hline 106 & $\# 5$ & 18:45 & $27 / 05 / 2017$ & Coleta & 2,88 & 8,3709 & 0,0000 & 0 & 94,8894 & 5,0581 & 1213 & 23,1 & 7,56 & 256,58 & 0,02 \\
\hline 107 & \# 5 & - & $29 / 05 / 2017$ & Branco & 2,88 & 0,0000 & 0,3169 & 0,0000 & 0,0000 & 0,0000 & - & - & - & - & - \\
\hline 108 & $\# 5$ & 08:30 & $29 / 05 / 2017$ & Coleta & 2,88 & 8,5142 & 0,0746 & 0,2918 & 97,514 & 7,2049 & 1208 & 23,7 & 7,15 & 262,08 & 0,01 \\
\hline 109 & $\# 5$ & 09:30 & $29 / 05 / 2017$ & Coleta & 2,88 & 8,3375 & 0,5419 & 0,9371 & 89,3012 & 6,8705 & 1176 & 23,6 & 7,22 & 273,60 & 0,01 \\
\hline 110 & $\# 5$ & $10: 30$ & 29/05/2017 & Coleta & 2,88 & 8,2064 & 1,0364 & 1,7327 & 90,5538 & 7,39 & 1178 & 23,6 & 7,18 & 276,48 & 0,02 \\
\hline 111 & $\# 5$ & $11: 30$ & 29/05/2017 & Coleta & 2,88 & 8,2884 & 1,13 & 1,8357 & 57,5377 & 7,3519 & 1196 & 23,7 & 7,23 & 274,64 & 0,01 \\
\hline 112 & $\# 5$ & $12: 30$ & $29 / 05 / 2017$ & Coleta & 2,88 & 8,2293 & 1,1388 & 1,9057 & 92,7881 & 7,5769 & 1209 & 23,7 & 7,3 & 278,68 & 0,01 \\
\hline 113 & $\# 5$ & $13: 30$ & $29 / 05 / 2017$ & Coleta & 2,88 & 8,4318 & 1,0657 & 1,9369 & 93,0107 & 7,5881 & 1186 & 23,7 & 7,21 & 310,40 & 0,01 \\
\hline 114 & $\# 5$ & $14: 30$ & $29 / 05 / 2017$ & Coleta & 2,88 & 8,2238 & 1,0379 & 1,9446 & 93,2166 & 7,5595 & 1205 & 23,7 & 7,22 & 273,81 & 0,01 \\
\hline 115 & $\# 5$ & $15: 30$ & $29 / 05 / 2017$ & Coleta & 2,88 & 8,2329 & 1,0222 & 1,9253 & 92,95 & 7,4507 & 1203 & 23,8 & 7,22 & 280,49 & 0,02 \\
\hline 116 & $\# 5$ & - & 29/05/2017 & Catodo entrada & 2,88 & 7,4746 & 0,106 & 16,8793 & 51,8973 & 9,789 & - & - & - & - & - \\
\hline
\end{tabular}




\begin{tabular}{|c|c|c|c|c|c|c|c|c|c|c|c|c|c|c|c|}
\hline \multicolumn{5}{|c|}{ Analises } & \multirow{2}{*}{\begin{tabular}{|l|} 
L/dia \\
Taxa de aplicação \\
\end{tabular}} & \multirow{2}{*}{\begin{tabular}{|l}
$\mathrm{mg} / \mathrm{L}$ \\
Cloreto \\
\end{tabular}} & \multirow{2}{*}{\begin{tabular}{|l|}
$\mathrm{mg} / \mathrm{L}$ \\
Nitrito-N \\
\end{tabular}} & \multirow{2}{*}{\begin{tabular}{|l|}
$\mathrm{mg} / \mathrm{L}$ \\
Nitrato-N \\
\end{tabular}} & \multirow{2}{*}{\begin{tabular}{|l|}
$\mathrm{mg} / \mathrm{L}$ \\
Fosfato-P \\
\end{tabular}} & \multirow{2}{*}{\begin{tabular}{|l|}
$\mathrm{mg} / \mathrm{L}$ \\
Sulfato \\
\end{tabular}} & \multirow{2}{*}{\begin{tabular}{|l|}
$\mathrm{\mu S} / \mathrm{cm}$ \\
Condutividade \\
\end{tabular}} & \multirow{2}{*}{\begin{tabular}{|l|}
${ }^{\circ} \mathrm{C}$ \\
temperatura \\
\end{tabular}} & \multirow{2}{*}{ pH } & \multirow{2}{*}{\begin{tabular}{|l|}
$\mathrm{mg} \mathrm{CaCO} / \mathrm{L}$ \\
Alcalinidade \\
\end{tabular}} & \multirow{2}{*}{\begin{tabular}{|l}
$\mathrm{mA}$ \\
Corrente
\end{tabular}} \\
\hline & Teste & Hora & Data Coleta & Tipo & & & & & & & & & & & \\
\hline 117 & \# 5 & - & 29/05/2017 & Catodo entrada & 2,88 & 6,6478 & 0,0000 & 23,6426 & 49,331 & 10,3565 & - & - & - & - & - \\
\hline 118 & \# 5 & - & $29 / 05 / 2017$ & Anodo entrada & 2,88 & 9,0053 & 0,0000 & 0,0000 & 73,2514 & 3,6368 & - & - & - & - & - \\
\hline 119 & $\# 6$ & 10:00 & $01 / 06 / 2017$ & Coleta & 5,76 & 8,0948 & 0,2743 & 2,4482 & 90,8768 & 7,81 & 1204 & 23,8 & 7,13 & 271,72 & 0,01 \\
\hline 120 & $\# 6$ & 11:30 & $01 / 06 / 2017$ & Coleta & 5,76 & 8,0518 & 0,3108 & 2,4898 & 91,0996 & 7,7982 & 1200 & 23,7 & 7,14 & 271,72 & 0,01 \\
\hline 121 & $\# 6$ & $12: 30$ & $01 / 06 / 2017$ & Coleta & 5,76 & 8,0714 & 0,3428 & 2,359 & 91,1673 & 8,041 & 1198 & 23,7 & 7,13 & 268,80 & 0,01 \\
\hline 122 & \# 6 & $13: 30$ & $01 / 06 / 2017$ & Coleta & 5,76 & 8,0601 & 0,3404 & 2,4771 & 91,5225 & 7,9073 & 1202 & 23,8 & 7,11 & 271,72 & 0,01 \\
\hline 123 & \#6 & 17:00 & $01 / 06 / 2017$ & Coleta & 5,76 & 8,0271 & 0,4673 & 2,3706 & 91,9046 & 7,9036 & 1199 & 23,7 & 7,23 & 268,80 & 0,02 \\
\hline 124 & \# 6 & 18:00 & $01 / 06 / 2017$ & Coleta & 5,76 & 8,0087 & 0,4345 & 2,1613 & 90,8532 & 7,8021 & 1195 & 23,2 & 7,26 & 274,64 & 0,02 \\
\hline 125 & $\# 6$ & 19:00 & $01 / 06 / 2017$ & Coleta & 5,76 & 7,8982 & 0,533 & 2,3619 & 91,8843 & 7,761 & 1194 & 23,6 & 7,23 & 268,80 & 0,02 \\
\hline 126 & $\# 6$ & 20:00 & $01 / 06 / 2017$ & Coleta & 5,76 & 8,0749 & 0,6918 & 2,2593 & 93,2558 & 8,0843 & 1203 & 23,4 & 7,18 & 268,80 & 0,02 \\
\hline 127 & \#6 & 18:00 & $01 / 06 / 2017$ & Anodo reator & 5,76 & 8,7656 & 0,0000 & 0,0000 & 55,1166 & 4,483 & 816 & 23,7 & 6,74 & 187,93 & - \\
\hline 128 & \#6 & 18:00 & $01 / 06 / 2017$ & Catodo reator & 5,76 & 8,1149 & 0,3887 & 2,6637 & 89,8521 & 8,1763 & 1170 & 23,8 & 7,24 & 273,36 & - \\
\hline 129 & \#6 & 18:00 & $01 / 06 / 2017$ & Catodo entrada & 5,76 & 7,3362 & 0,065 & 13,5322 & 54,032 & 10,2706 & 1526 & 23,5 & 7,23 & 289,25 & - \\
\hline 130 & \#6 & 18:00 & $01 / 06 / 2017$ & Anodo entrada & 5,76 & 9,4329 & 0,0000 & 0,0000 & 56,7937 & 6,741 & 918 & 23,2 & 7,22 & 216,21 & - \\
\hline 131 & \# 6 & - & $03 / 06 / 2017$ & Branco & 5,76 & 0,9641 & 0,0000 & 0,0000 & 0,0000 & 0,0000 & - & - & - & - & - \\
\hline 132 & \#6 & - & 03/06/2017 & Coleta & 5,76 & 8,9831 & 0,4503 & 0 & 102,1396 & 0,0000 & - & - & - & - & - \\
\hline 133 & \#6 & 10:00 & 03/06/2017 & Coleta & 5,76 & 8,7641 & 0,0000 & 0,3011 & 38,6316 & 7,1079 & 1275 & 21,5 & 7,54 & 313,11 & 0,01 \\
\hline 134 & \#6 & 11:00 & 03/06/2017 & Coleta & 5,76 & 9,3808 & 0,0000 & 0 & 87,8314 & 5,3856 & 1124 & 23,2 & 7,17 & 308,80 & 0,02 \\
\hline 135 & \#6 & 12:00 & 03/06/2017 & Coleta & 5,76 & 8,7424 & 0,2484 & 1,6309 & 98,4452 & 6,8762 & 1252 & 23,2 & 7,27 & 313,06 & 0,02 \\
\hline 136 & \#6 & - & 03/06/2017 & Catodo entrada & 5,76 & 7,1884 & 0,0651 & 13,1712 & 61,5333 & 9,9309 & - & - & - & - & - \\
\hline 137 & \#6 & - & 05/06/2017 & Branco & 5,76 & 0,0000 & 0,0000 & 0,0000 & 0,0000 & 0,0000 & - & - & - & - & - \\
\hline 138 & \#6 & - & 05/06/2017 & Catodo entrada & 5,76 & 6,8905 & 0,0000 & 11,3827 & 129,0063 & 1,5736 & - & - & - & - & - \\
\hline 139 & \# 6 & 09:00 & $05 / 06 / 2017$ & Coleta & 5,76 & 8,1933 & 0,9712 & 6,4115 & 99,9608 & 9,125 & 1327 & 23 & 7,28 & 336,00 & 0,01 \\
\hline 140 & \# 6 & $10: 00$ & 05/06/2017 & Coleta & 5,76 & 8,3309 & 0,8919 & 5,8374 & 97,0146 & 8,9001 & 1299 & 23 & 7,26 & 293,76 & 0,00 \\
\hline 141 & \#6 & 11:00 & $05 / 06 / 2017$ & Coleta & 5,76 & 8,3174 & 0,9791 & 6,1346 & 98,4795 & 8,7478 & 1294 & 23,1 & 7,3 & 290,88 & 0,01 \\
\hline 142 & \#6 & $12: 00$ & 05/06/2017 & Coleta & 5,76 & 8,1291 & 1,0541 & 6,3604 & 98,7458 & 8,4658 & 1293 & 22,9 & 7,26 & 288,83 & 0,00 \\
\hline 143 & \#6 & 13:00 & 05/06/2017 & Coleta & 5,76 & 8,2592 & 1,0953 & 6,4837 & 98,9243 & 8,4348 & 1315 & 22,8 & 7,36 & 318,94 & 0,01 \\
\hline 144 & \#6 & 13:00 & $05 / 06 / 2017$ & Coleta & 5,76 & 8,6846 & 0,7035 & 5,6322 & 99,5008 & 8,4833 & - & - & - & - & - \\
\hline 145 & \# 6 & 14:00 & 05/06/2017 & Coleta & 5,76 & 8,0974 & 1,1083 & 6,6916 & 99,2488 & 8,596 & 1315 & 23 & 7,33 & 305,54 & - \\
\hline
\end{tabular}




\begin{tabular}{|c|c|c|c|c|c|c|c|c|c|c|c|c|c|c|c|}
\hline \multicolumn{5}{|c|}{ Analises } & \multirow{2}{*}{$\begin{array}{l}\text { L/dia } \\
\text { Taxa de aplicação }\end{array}$} & \multirow{2}{*}{\begin{tabular}{l|}
$\mathrm{mg} / \mathrm{L}$ \\
Cloreto
\end{tabular}} & \multirow{2}{*}{\begin{tabular}{|l|}
$\mathrm{mg} / \mathrm{L}$ \\
Nitrito-N
\end{tabular}} & \multirow{2}{*}{\begin{tabular}{|l|}
$\mathrm{mg} / \mathrm{L}$ \\
Nitrato-N \\
\end{tabular}} & \multirow{2}{*}{\begin{tabular}{|l|}
$\mathrm{mg} / \mathrm{L}$ \\
Fosfato-P
\end{tabular}} & \multirow{2}{*}{\begin{tabular}{|l|}
$\mathrm{mg} / \mathrm{L}$ \\
Sulfato
\end{tabular}} & \multirow{2}{*}{\begin{tabular}{l|}
$\mu \mathrm{S} / \mathrm{cm}$ \\
Condutividade
\end{tabular}} & \multirow{2}{*}{\begin{tabular}{|l|}
${ }^{\circ} \mathrm{C}$ \\
temperatura
\end{tabular}} & \multirow{2}{*}{$\begin{array}{l}- \\
\mathrm{pH}\end{array}$} & \multirow{2}{*}{\begin{tabular}{|l|}
$\mathrm{mg} \mathrm{CaCO} / \mathrm{L}$ \\
Alcalinidade
\end{tabular}} & \multirow{2}{*}{$\begin{array}{l}\mathrm{mA} \\
\text { Corrente }\end{array}$} \\
\hline & Teste & Hora & Data Coleta & Tipo & & & & & & & & & & & \\
\hline 146 & $\# 6$ & $15: 00$ & 05/06/2017 & Coleta & 5,76 & 8,2213 & 1,2088 & 6,7903 & 99,5193 & 8,4699 & 1320 & 23,1 & 7,39 & 291,71 & - \\
\hline 147 & $\# 6$ & $16: 00$ & 05/06/2017 & Coleta & 5,76 & 8,1103 & 1,1953 & 6,59 & 98,5949 & 8,6071 & 1317 & 23 & 7,38 & 297,75 & - \\
\hline 148 & $\# 6$ & $17: 10$ & 05/06/2017 & Coleta & 5,76 & 8,1237 & 1,7424 & 6,4606 & 98,3595 & 8,3775 & 1310 & 23,2 & 7,4 & 292,80 & 0,01 \\
\hline 149 & $\# 6$ & $18: 10$ & 05/06/2017 & Coleta & 5,76 & 8,5566 & 1,0967 & 3,0614 & 91,3654 & 7,301 & 1302 & 23,2 & 7,39 & 296,47 & 0,01 \\
\hline 150 & $\# 6$ & - & 05/06/2017 & Catodo entrada & 5,76 & 6,6342 & 0,0000 & 22,8058 & 125,5169 & 10,1027 & - & - & - & - & - \\
\hline 151 & $\# 6$ & - & 05/06/2017 & Anodo reator & 5,76 & 8,9005 & 0,9461 & 3,4946 & 91,4566 & 7,465 & - & - & - & - & - \\
\hline 152 & $\# 6$ & - & 05/06/2017 & Anodo reator & 5,76 & 8,1149 & 1,2391 & 6,224 & 97,3472 & 8,2056 & - & - & - & - & - \\
\hline 153 & $\# 7$ & $10: 00$ & $10 / 06 / 2017$ & Catodo entrada & 5,76 & 6,4643 & 0,0000 & 11,2612 & 71,2438 & 10,0331 & - & - & - & - & - \\
\hline 154 & $\# 7$ & 13:00 & $10 / 06 / 2017$ & Coleta & 5,76 & 7,9093 & 0,1591 & 2,8267 & 49,6372 & 7,5914 & 1230 & 21,8 & 7,52 & 233,91 & 101,00 \\
\hline 155 & $\# 7$ & $14: 00$ & $10 / 06 / 2017$ & Coleta & 5,76 & 7,8654 & 0,1163 & 2,8154 & 48,8582 & 7,3879 & 1221 & 21,9 & 7,38 & 296,80 & 102,00 \\
\hline 156 & $\# 7$ & $15: 00$ & 10/06/2017 & Coleta & 5,76 & 7,8344 & 0,0753 & 2,8537 & 52,229 & 7,1956 & 1230 & 21,8 & 7,38 & 296,47 & 101,00 \\
\hline 157 & $\# 7$ & 16:00 & $10 / 06 / 2017$ & Coleta & 5,76 & 7,9134 & 0,1196 & 2,8561 & 82,4277 & 7,108 & 1225 & 22 & 7,4 & 295,30 & 103,00 \\
\hline 158 & $\# 7$ & $17: 00$ & \begin{tabular}{|l|}
$10 / 06 / 2017$ \\
\end{tabular} & Coleta & 5,76 & 7,8045 & 0,1343 & 2,8675 & 53,6727 & 7,0761 & 1226 & 22,5 & 7,42 & 293,51 & 101,00 \\
\hline 159 & $\# 7$ & 18:00 & $10 / 06 / 2017$ & Coleta & 5,76 & 7,9569 & 0,1813 & 2,9636 & 54,9255 & 7,1618 & 1227 & 22,2 & 7,37 & 292,17 & 102,00 \\
\hline 160 & $\# 7$ & $12: 00$ & $10 / 06 / 2017$ & Anodo entrada & 5,76 & 9,0802 & 0,0000 & 0,0000 & 62,7589 & 5,2153 & 1009 & 21,8 & 7,41 & 266,11 & - \\
\hline 161 & $\# 7$ & $16: 00$ & $10 / 06 / 2017$ & Anodo reator & 5,76 & 8,5371 & 0,0000 & 0,529 & 45,2611 & 6,1087 & 1110 & 22 & 7,39 & 268,80 & - \\
\hline 162 & $\# 7$ & $12: 00$ & $10 / 06 / 2017$ & Catodo entrada & 5,76 & 6,2672 & 0,0000 & 11,0622 & 88,466 & 10,1009 & 1447 & 21,8 & 7,38 & 297,09 & - \\
\hline 163 & $\# 7$ & $08: 30$ & $12 / 06 / 2017$ & Coleta & 5,76 & 7,8878 & 0,2213 & 3,4227 & 47,8147 & 6,0024 & 1225 & 20,7 & 7,39 & 264,60 & 101,00 \\
\hline 164 & $\# 7$ & $09: 30$ & $12 / 06 / 2017$ & Coleta & 5,76 & 7,8480 & 0,1603 & 3,1735 & 47,6960 & 6,0763 & 1216 & 20,6 & 7,3 & 260,13 & 102,00 \\
\hline 165 & $\# 7$ & $10: 30$ & $12 / 06 / 2017$ & Coleta & 5,76 & 7,9013 & 0,2124 & 2,7510 & 45,4661 & 6,6987 & 1215 & 20,7 & 7,32 & 264,60 & 101,00 \\
\hline 166 & $\# 7$ & $11: 30$ & $12 / 06 / 2017$ & Coleta & 5,76 & 8,2347 & 0,1430 & 1,5338 & 41,9557 & 5,8222 & 1164 & 20,8 & 7,28 & 259,20 & 103,00 \\
\hline 167 & $\# 7$ & $12: 30$ & $12 / 06 / 2017$ & Coleta & 5,76 & 8,6882 & 0,0833 & 0,5763 & 80,8731 & 5,3388 & 1119 & 20,7 & 7,3 & 256,00 & 101,00 \\
\hline 168 & $\# 7$ & $14: 00$ & $12 / 06 / 2017$ & Coleta & 5,76 & 8,7294 & 0,0000 & 0,3651 & 75,3843 & 6,9033 & 1100 & 20,7 & 7,26 & 280,92 & 102,00 \\
\hline 169 & $\# 7$ & $15: 00$ & $12 / 06 / 2017$ & Coleta & 5,76 & 9,0037 & 0,0000 & 0 & 73,0858 & 6,3751 & 1088 & 20,9 & 7,26 & 255,15 & 102,00 \\
\hline 170 & $\# 7$ & $16: 00$ & $12 / 06 / 2017$ & Coleta & 5,76 & 8,9970 & 0,0000 & 0 & 71,6769 & 6,0299 & 1074 & 20,7 & 7,27 & 252,00 & - \\
\hline 171 & $\# 7$ & - & $13 / 06 / 2017$ & Catodo entrada & 5,76 & 7,8395 & 0,0000 & 10,5898 & 61,4347 & 8,1807 & 1349 & 20,7 & 7,15 & 236,25 & - \\
\hline 172 & $\# 7$ & $12: 00$ & $13 / 06 / 2017$ & Coleta & 5,76 & 9,2551 & 0,1977 & 1,5043 & 77,2574 & 6,0468 & 1141 & 20,6 & 7,55 & 246,02 & 101,00 \\
\hline 173 & $\# 7$ & 13:00 & $13 / 06 / 2017$ & Coleta & 5,76 & 9,0066 & 0,2897 & 3,0983 & 47,9817 & 5,6320 & 1263 & 20,6 & 7,29 & 272,16 & 100 \\
\hline 174 & $\# 7$ & $14: 00$ & 13/06/2017 & Coleta & 5,76 & 9,0980 & 0,3705 & 3,4428 & 52,7070 & 6,5180 & 1312 & 20,6 & 7,28 & 280,19 & 101,00 \\
\hline
\end{tabular}




\begin{tabular}{|c|c|c|c|c|c|c|c|c|c|c|c|c|c|c|c|}
\hline \multicolumn{5}{|c|}{ Analises } & \multirow{2}{*}{\begin{tabular}{|l|} 
L/dia \\
Taxa de aplicação \\
\end{tabular}} & \multirow{2}{*}{\begin{tabular}{|l|}
$\mathrm{mg} / \mathrm{L}$ \\
Cloreto \\
\end{tabular}} & \multirow{2}{*}{\begin{tabular}{|l|}
$\mathrm{mg} / \mathrm{L}$ \\
Nitrito-N \\
\end{tabular}} & \multirow{2}{*}{\begin{tabular}{|l|}
$\mathrm{mg} / \mathrm{L}$ \\
Nitrato-N \\
\end{tabular}} & \multirow{2}{*}{\begin{tabular}{|l|}
$\mathrm{mg} / \mathrm{L}$ \\
Fosfato-P
\end{tabular}} & \multirow{2}{*}{\begin{tabular}{|l|}
$\mathrm{mg} / \mathrm{L}$ \\
Sulfato \\
\end{tabular}} & \multirow{2}{*}{$\begin{array}{l}\mu \mathrm{S} / \mathrm{cm} \\
\text { Condutividade }\end{array}$} & \multirow{2}{*}{\begin{tabular}{|l|}
${ }^{\circ} \mathrm{C}$ \\
temperatura \\
\end{tabular}} & \multirow{2}{*}{$\begin{array}{l}- \\
\mathrm{pH}\end{array}$} & \multirow{2}{*}{\begin{tabular}{|l|}
$\mathrm{mg} \mathrm{CaCO} / \mathrm{L}$ \\
Alcalinidade \\
\end{tabular}} & \multirow{2}{*}{\begin{tabular}{|l|}
$\mathrm{mA}$ \\
Corrente
\end{tabular}} \\
\hline & Teste & Hora & Data Coleta & Tipo & & & & & & & & & & & \\
\hline 175 & \# 7 & 15:00 & 13/06/2017 & Coleta & 5,76 & 8,8362 & 0,3642 & 3,6273 & 53,3714 & 6,7248 & 1324 & 20,4 & 7,27 & 275,52 & 100 \\
\hline 176 & $\# 7$ & $16: 00$ & $13 / 06 / 2017$ & Coleta & 5,76 & 9,0283 & 0,2231 & 2,6454 & 46,5678 & 5,3008 & 1240 & 20,6 & 7,49 & 273,36 & 100 \\
\hline 177 & $\# 7$ & $17: 30$ & $13 / 06 / 2017$ & Coleta & 5,76 & 8,8152 & 0,3645 & 3,5896 & 54,7478 & 6,9579 & 1335 & 20,7 & 7,25 & 273,36 & 102,00 \\
\hline 178 & $\# 7$ & $18: 30$ & $13 / 06 / 2017$ & Coleta & 5,76 & 8,7922 & 0,3522 & 3,8962 & 56,2982 & 6,9974 & 1341 & 21,4 & 7,26 & 287,02 & 102,00 \\
\hline 179 & $\# 7$ & 19:30 & 13/06/2017 & Coleta & 5,76 & 8,6618 & 0,3407 & 3,4716 & 54,5298 & 6,9123 & 1328 & 22 & 7,29 & 272,53 & - \\
\hline 180 & $\# 7$ & - & $13 / 06 / 2017$ & Catodo entrada & 5,76 & 7,7401 & 0,0000 & 10,5802 & 63,7755 & 7,9186 & 1349 & 20,7 & 7,15 & 236,25 & - \\
\hline 181 & $\# 7$ & - & $13 / 06 / 2017$ & Anodo reator & 5,76 & 8,9923 & 0,4915 & 2,5010 & 49,3542 & 6,2487 & 1247 & 21,4 & 7,19 & 265,26 & - \\
\hline 182 & $\# 7$ & - & $13 / 06 / 2017$ & Anodo entrada & 5,76 & - & - & - & - & - & 1018 & 20,4 & 7,37 & 238,82 & - \\
\hline 183 & \# 7 & - & $14 / 06 / 2017$ & Branco & 5,76 & 0,0000 & 0,0000 & 0,0000 & 0,0000 & 0,0000 & - & - & - & - & - \\
\hline 184 & $\# 7$ & 09:30 & $14 / 06 / 2017$ & Coleta & 5,76 & 8,7022 & 0,0000 & 0 & 100,9024 & 0,0000 & 1274 & 21,9 & 7,3 & 268,80 & 101,00 \\
\hline 185 & $\# 7$ & $10: 30$ & $14 / 06 / 2017$ & Coleta & 5,76 & 8,6776 & 0,1329 & 3,9154 & 55,8301 & 7,8537 & 1301 & 21,4 & 7,1 & 266,82 & 100 \\
\hline 186 & $\# 7$ & 11:30 & $14 / 06 / 2017$ & Coleta & 5,76 & 8,6353 & 0,1686 & 3,9489 & 53,5390 & 7,7905 & 1293 & 21,4 & 7,12 & 271,38 & 101,00 \\
\hline 187 & $\# 7$ & 12:30 & 14/06/2017 & Coleta & 5,76 & 8,6811 & 0,1589 & 3,9926 & 53,6877 & 7,9147 & 1292 & 21,3 & 7,12 & 266,82 & 100 \\
\hline 188 & $\# 7$ & 13:30 & $14 / 06 / 2017$ & Coleta & 5,76 & 8,7590 & 0,1577 & 3,8139 & 51,1497 & 7,9386 & 1286 & 21,3 & 7,2 & 265,88 & 101,00 \\
\hline 189 & $\# 7$ & $14: 40$ & 14/06/2017 & Coleta & 5,76 & 8,7776 & 0,1347 & 3,8427 & 51,2695 & 8,0269 & 1267 & 21,3 & 7,18 & 259,20 & 102,00 \\
\hline 190 & $\# 7$ & - & $14 / 06 / 2017$ & Coleta & 5,76 & 8,7508 & 0,1633 & 3,8423 & 45,5908 & 7,5523 & - & - & - & - & 100 \\
\hline 191 & $\# 7$ & - & $14 / 06 / 2017$ & Catodo entrada & 5,76 & 6,5551 & 0,0000 & 11,6824 & 67,8343 & 9,7536 & - & - & - & - & - \\
\hline 192 & $\# 7$ & - & $14 / 06 / 2017$ & Anodo reator & 5,76 & 9,6153 & 0,1214 & 2,9521 & 82,9605 & 6,9256 & - & - & - & - & - \\
\hline 193 & $\# 7$ & - & $19 / 06 / 2017$ & Branco & 5,76 & 0,0000 & 0,0000 & 0,6560 & 0,0000 & 0,0000 & - & - & - & - & - \\
\hline 194 & $\# 7$ & 13:00 & 19/06/2017 & Coleta & 5,76 & 8,8555 & 0,0000 & 0 & 100,4767 & 0,0000 & 1323 & 21,6 & 7,23 & 292,65 & 102 \\
\hline 195 & $\# 7$ & $14: 00$ & 19/06/2017 & Coleta & 5,76 & 8,6692 & 0,2136 & 3,8359 & 105,9221 & 6,0053 & 1263 & 21,4 & 7,25 & 277,96 & 101 \\
\hline 196 & $\# 7$ & $15: 00$ & $19 / 06 / 2017$ & Coleta & 5,76 & 9,0751 & 0,0983 & 2,2421 & 53,5068 & 7,1433 & 1286 & 21,5 & 7,28 & 278,07 & 101 \\
\hline 197 & $\# 7$ & 16:00 & 19/06/2017 & Coleta & 5,76 & 0,0000 & 0,0875 & 2,6116 & 52,8652 & 7,4683 & 1294 & 21,4 & 7,31 & 278,07 & 102 \\
\hline 198 & $\# 7$ & $17: 00$ & 19/06/2017 & Coleta & 5,76 & 8,5050 & 0,0977 & 2,0622 & 53,4909 & 7,4473 & 1293 & 21,3 & 7,29 & 274,91 & 100 \\
\hline 199 & $\# 7$ & 18:00 & $19 / 06 / 2017$ & Coleta & 5,76 & 8,6403 & 0,1017 & 2,6114 & 51,0055 & 7,4942 & 1282 & 21,2 & 7,29 & 274,09 & 100 \\
\hline 200 & $\# 7$ & 19:00 & 19/06/2017 & Coleta & 5,76 & 8,9885 & 0,0988 & 2,5741 & 48,9109 & 7,5967 & 1285 & 21,5 & 7,28 & 276,61 & 102 \\
\hline 201 & $\# 7$ & $20: 00$ & 19/06/2017 & Coleta & 5,76 & 8,9530 & 0,1433 & 2,6622 & 50,1343 & 7,8485 & 1286 & 21,4 & 7,28 & 274,27 & 102 \\
\hline 202 & $\# 7$ & 18:00 & $19 / 06 / 2017$ & Catodo entrada & 5,76 & 7,4751 & 0,0536 & 11,2659 & 63,8234 & 8,3355 & 1415 & 21,4 & 7,35 & 276,00 & - \\
\hline 203 & $\# 7$ & 18:00 & 19/06/2017 & Anodo entrada & 5,76 & 10,8335 & 0,0000 & 0,0000 & 73,6154 & 7,1216 & 1147 & 21,3 & 7,29 & 239,68 & - \\
\hline
\end{tabular}




\begin{tabular}{|c|c|c|c|c|c|c|c|c|c|c|c|c|c|c|c|}
\hline \multicolumn{5}{|c|}{ Analises } & \multirow{2}{*}{$\begin{array}{l}\text { L/dia } \\
\text { Taxa de aplicação }\end{array}$} & \multirow{2}{*}{\begin{tabular}{l|}
$\mathrm{mg} / \mathrm{L}$ \\
Cloreto
\end{tabular}} & \multirow{2}{*}{\begin{tabular}{|l|}
$\mathrm{mg} / \mathrm{L}$ \\
Nitrito-N
\end{tabular}} & \multirow{2}{*}{\begin{tabular}{|l|}
$\mathrm{mg} / \mathrm{L}$ \\
Nitrato-N \\
\end{tabular}} & \multirow{2}{*}{\begin{tabular}{|l|}
$\mathrm{mg} / \mathrm{L}$ \\
Fosfato-P
\end{tabular}} & \multirow{2}{*}{\begin{tabular}{|l|}
$\mathrm{mg} / \mathrm{L}$ \\
Sulfato
\end{tabular}} & \multirow{2}{*}{\begin{tabular}{l|}
$\mu \mathrm{S} / \mathrm{cm}$ \\
Condutividade
\end{tabular}} & \multirow{2}{*}{\begin{tabular}{|l|}
${ }^{\circ} \mathrm{C}$ \\
temperatura
\end{tabular}} & \multirow{2}{*}{$\begin{array}{l}- \\
\mathrm{pH}\end{array}$} & \multirow{2}{*}{\begin{tabular}{|l|}
$\mathrm{mg} \mathrm{CaCO} / \mathrm{L}$ \\
Alcalinidade
\end{tabular}} & \multirow{2}{*}{$\begin{array}{l}\mathrm{mA} \\
\text { Corrente }\end{array}$} \\
\hline & Teste & Hora & Data Coleta & Tipo & & & & & & & & & & & \\
\hline 204 & $\# 7$ & $18: 00$ & 19/06/2017 & Anodo reator & 5,76 & 9,2648 & 0,0000 & 0,0000 & 46,4211 & 6,3688 & 1265 & 21,4 & 7,43 & 274,91 & - \\
\hline 205 & $\# 8$ & - & 23/06/2017 & Catodo entrada & 5,76 & 6,8329 & 0,0000 & 12,5192 & 78,9991 & 11,3958 & - & - & - & - & - \\
\hline 206 & $\# 8$ & - & 23/06/2017 & Branco & 5,76 & 1,3413 & 0,0000 & 0,0000 & 0,6387 & 0,0000 & - & - & - & - & - \\
\hline 207 & $\# 8$ & - & $23 / 06 / 2017$ & Catodo entrada & 5,76 & 6,7938 & 0,0000 & 12,2661 & 63,5084 & 8,3160 & - & - & - & - & - \\
\hline 208 & $\# 8$ & 09:00 & 23/06/2017 & Coleta & 5,76 & 10,4472 & 0,0623 & 0,4452 & 73,6793 & 5,1836 & 1175 & 21,2 & 7,53 & 268,80 & - \\
\hline 209 & $\# 8$ & $10: 00$ & $23 / 06 / 2017$ & Coleta & 5,76 & 9,9882 & 0,1294 & 1,3252 & 37,0424 & 5,6144 & 1210 & 21,1 & 7,28 & 272,16 & - \\
\hline 210 & $\# 8$ & $12: 00$ & $23 / 06 / 2017$ & Coleta & 5,76 & 9,1286 & 0,3000 & 3,4461 & 50,4035 & 7,9039 & 1299 & 21,1 & 7,24 & 260,13 & - \\
\hline 211 & $\# 8$ & $13: 00$ & $23 / 06 / 2017$ & Coleta & 5,76 & 9,2824 & 0,2552 & 4,2412 & 53,3754 & 8,0832 & 1342 & 21,1 & 7,51 & 252,00 & - \\
\hline 212 & $\# 8$ & $14: 00$ & $23 / 06 / 2017$ & Coleta & 5,76 & 8,8242 & 0,1711 & 4,9872 & 53,5671 & 8,0577 & 1340 & 21 & 7,37 & 248,64 & - \\
\hline 213 & $\# 8$ & $15: 00$ & $23 / 06 / 2017$ & Coleta & 5,76 & 8,8038 & 0,1570 & 5,0423 & 52,3336 & 8,1230 & 1351 & 21,2 & 7,43 & 248,64 & - \\
\hline 214 & $\# 8$ & - & $23 / 06 / 2017$ & Anodo reator & 5,76 & 9,4898 & 0,1847 & 2,7188 & 43,9354 & 7,7882 & - & - & - & - & - \\
\hline 215 & $\# 8$ & - & $24 / 06 / 2017$ & Catodo entrada & 5,76 & 6,6477 & 0,0000 & 23,8732 & 76,1752 & 11,2605 & 1680 & 21,6 & 7,31 & 257,21 & - \\
\hline 216 & $\# 8$ & $12: 00$ & $24 / 06 / 2017$ & Coleta & 5,76 & 8,8039 & 0,1602 & 7,4399 & 50,2801 & 8,2334 & 1383 & 21,5 & 7,59 & 262,08 & 210 \\
\hline 217 & $\# 8$ & 13:00 & $24 / 06 / 2017$ & Coleta & 5,76 & 8,7004 & 0,2012 & 8,5438 & 48,3441 & 8,1820 & 1395 & 21,5 & 7,42 & 285,60 & 215 \\
\hline 218 & $\# 8$ & $14: 00$ & $24 / 06 / 2017$ & Coleta & 5,76 & 8,6600 & 0,1564 & 8,8022 & 48,8854 & 8,2366 & 1404 & 22 & 7,4 & 261,33 & 207 \\
\hline 219 & $\# 8$ & $15: 00$ & $24 / 06 / 2017$ & Coleta & 5,76 & 8,6317 & 0,1587 & 10,0821 & 49,4096 & 8,4096 & 1417 & 21,9 & 7,39 & 257,21 & 210 \\
\hline 220 & $\# 8$ & $16: 00$ & $24 / 06 / 2017$ & Coleta & 5,76 & 8,8241 & 0,1743 & 9,5756 & 50,2099 & 8,3361 & 1406 & 22,6 & 7,49 & 255,36 & 223 \\
\hline 221 & $\# 8$ & $17: 00$ & $24 / 06 / 2017$ & Coleta & 5,76 & 8,8392 & 0,1813 & 9,5862 & 49,2064 & 8,2019 & 1402 & 22,9 & 7,46 & 253,63 & 225 \\
\hline 222 & $\# 8$ & $15: 00$ & $24 / 06 / 2017$ & Anodo reator & 5,76 & 9,6581 & 0,2611 & 4,8206 & 92,6398 & 7,9612 & 1312 & 21,9 & 7,32 & 247,80 & - \\
\hline 223 & $\# 8$ & $16: 00$ & $24 / 06 / 2017$ & Catodo entrada & 5,76 & 6,7055 & 0,0000 & 23,7017 & 68,2820 & 11,2318 & 1680 & 21,6 & 7,31 & 257,21 & - \\
\hline 224 & $\# 8$ & $15: 00$ & $24 / 06 / 2017$ & Anodo entrada & 5,76 & 10,8216 & 0,0000 & 0,0000 & 74,9187 & 6,1128 & 1156 & 21,8 & 7,51 & 252,00 & - \\
\hline 225 & $\# 8$ & - & $24 / 06 / 2017$ & Coleta & 5,76 & 9,5191 & 0,1583 & 8,9885 & 50,8191 & 8,6457 & - & - & - & - & - \\
\hline 226 & $\# 8$ & - & 26/06/2017 & Branco & 5,76 & 1,2019 & 0,0000 & 0,0000 & 0,0000 & 0,9261 & - & - & - & - & - \\
\hline 227 & $\# 8$ & - & $26 / 06 / 2017$ & Catodo entrada & 5,76 & 6,9548 & 0,0000 & 24,2565 & 70,9500 & 8,2898 & 1680 & 21,2 & 7,15 & 281,65 & - \\
\hline 228 & $\# 8$ & - & $26 / 06 / 2017$ & Anodo entrada & 5,76 & 9,5499 & 0,0000 & 0,0000 & 65,8117 & 6,0237 & 1119 & 20,9 & 7,25 & 204,75 & - \\
\hline 229 & $\# 8$ & - & 26/06/2017 & Anodo reator & 5,76 & 7,9273 & 0,8523 & 5,5597 & 49,5799 & 8,6547 & 1413 & 21,3 & 7,51 & 282,89 & - \\
\hline 230 & $\# 8$ & $11: 00$ & 26/06/2017 & Coleta & 5,76 & 7,6992 & 0,6589 & 5,8988 & 49,6077 & 8,8980 & 1386 & 21,3 & 7,52 & 288,96 & 201 \\
\hline 231 & $\# 8$ & $12: 00$ & $26 / 06 / 2017$ & Coleta & 5,76 & 7,7286 & 0,5327 & 5,4142 & 48,8484 & 8,8514 & 1371 & 21,2 & 7,4 & 268,80 & 200 \\
\hline 232 & $\# 8$ & $13: 00$ & 26/06/2017 & Coleta & 5,76 & 7,7068 & 0,6703 & 5,5684 & 49,5111 & 8,7340 & 1383 & 21,3 & 7,43 & 270,33 & 201 \\
\hline
\end{tabular}




\begin{tabular}{|c|c|c|c|c|c|c|c|c|c|c|c|c|c|c|c|}
\hline \multicolumn{5}{|c|}{ Analises } & \multirow{2}{*}{\begin{tabular}{|l|} 
L/dia \\
Taxa de aplicação
\end{tabular}} & \multirow{2}{*}{\begin{tabular}{|l|}
$\mathrm{mg} / \mathrm{L}$ \\
Cloreto \\
\end{tabular}} & \multirow{2}{*}{\begin{tabular}{|l|}
$\mathrm{mg} / \mathrm{L}$ \\
Nitrito-N \\
\end{tabular}} & \multirow{2}{*}{\begin{tabular}{|l|}
$\mathrm{mg} / \mathrm{L}$ \\
Nitrato-N \\
\end{tabular}} & \multirow{2}{*}{\begin{tabular}{|l|}
$\mathrm{mg} / \mathrm{L}$ \\
Fosfato-P
\end{tabular}} & \multirow{2}{*}{\begin{tabular}{|l|}
$\mathrm{mg} / \mathrm{L}$ \\
Sulfato \\
\end{tabular}} & \multirow{2}{*}{\begin{tabular}{|l|}
$\mu \mathrm{S} / \mathrm{cm}$ \\
Condutividade \\
\end{tabular}} & \multirow{2}{*}{\begin{tabular}{|l|}
${ }^{\circ} \mathrm{C}$ \\
temperatura
\end{tabular}} & \multirow{2}{*}{$\begin{array}{l}- \\
\mathrm{pH}\end{array}$} & \multirow{2}{*}{\begin{tabular}{|c|}
$\mathrm{mg} \mathrm{CaCO} / \mathrm{L}$ \\
Alcalinidade \\
\end{tabular}} & \multirow{2}{*}{\begin{tabular}{|l|}
$\mathrm{mA}$ \\
Corrente
\end{tabular}} \\
\hline & Teste & Hora & Data Coleta & Tipo & & & & & & & & & & & \\
\hline 233 & $\# 8$ & $14: 00$ & $26 / 06 / 2017$ & Coleta & 5,76 & 7,7382 & 0,6115 & 6,3445 & 50,6707 & 8,7490 & 1385 & 21,2 & 7,35 & 268,80 & 201 \\
\hline 234 & $\# 8$ & $15: 00$ & $26 / 06 / 2017$ & Coleta & 5,76 & 8,0435 & 0,5701 & 6,6397 & 49,2694 & 8,4640 & 1385 & 21,4 & 7,33 & 265,44 & 201 \\
\hline 235 & $\# 8$ & $16: 00$ & 26/06/2017 & Coleta & 5,76 & 7,7695 & 0,5131 & 7,2981 & 50,7322 & 8,1898 & 1373 & 21,4 & 7,32 & 262,08 & 201 \\
\hline 236 & $\# 8$ & $17: 00$ & $26 / 06 / 2017$ & Coleta & 5,76 & 7,7224 & 0,5202 & 7,2584 & 49,0090 & 8,8053 & 1414 & 22,5 & 7,43 & 273,22 & 200 \\
\hline 237 & $\# 8$ & 18:00 & $26 / 06 / 2017$ & Coleta & 5,76 & 7,7782 & 0,5328 & 6,7256 & 51,0199 & 8,9054 & 1418 & 22,9 & 7,5 & 267,64 & 247 \\
\hline 238 & $\# 8$ & - & $27 / 06 / 2017$ & Catodo entrada & 5,76 & 6,4364 & 0,0000 & 24,6818 & 80,8334 & 11,2641 & 1718 & 21,3 & 7,3 & 271,85 & - \\
\hline 239 & $\# 8$ & 10:00 & $27 / 06 / 2017$ & Coleta & 5,76 & 7,7963 & 0,5633 & 6,5638 & 50,4205 & 8,3565 & 1416 & 21,2 & 7,51 & 278,88 & 201 \\
\hline 240 & $\# 8$ & $11: 00$ & $27 / 06 / 2017$ & Coleta & 5,76 & 7,8102 & 0,6046 & 6,8050 & 50,5119 & 7,1675 & 1354 & 21,3 & 7,18 & 265,44 & 200 \\
\hline 241 & $\# 8$ & $13: 00$ & $27 / 06 / 2017$ & Coleta & 5,76 & 7,6748 & 0,6383 & 5,5364 & 49,4791 & 8,7020 & 1340 & 21,4 & 7,19 & 255,36 & 200 \\
\hline 242 & $\# 8$ & $14: 00$ & $27 / 06 / 2017$ & Coleta & 5,76 & 7,7062 & 0,5795 & 6,3125 & 50,6387 & 8,7170 & 1341 & 21,4 & 7,22 & 262,08 & 200 \\
\hline 243 & $\# 8$ & $15: 00$ & $27 / 06 / 2017$ & Coleta & 5,76 & 8,0115 & 0,5381 & 6,6077 & 49,2374 & 8,4320 & 1339 & 21,4 & 7,27 & 262,08 & 200 \\
\hline 244 & $\# 8$ & 16:00 & $27 / 06 / 2017$ & Coleta & 5,76 & 7,7375 & 0,4811 & 7,2661 & 50,7002 & 8,1578 & 1343 & 21,3 & 7,22 & 252,00 & - \\
\hline 245 & $\# 8$ & $17: 00$ & $27 / 06 / 2017$ & Coleta & 5,76 & 7,6904 & 0,4882 & 7,2264 & 48,9770 & 8,7733 & 1357 & 21,9 & 7,36 & 274,59 & 201 \\
\hline 246 & $\# 8$ & $18: 00$ & $27 / 06 / 2017$ & Coleta & 5,76 & 7,7462 & 0,5008 & 6,6936 & 50,9879 & 8,8734 & 1338 & 22,5 & 7,35 & 262,08 & 187 \\
\hline 247 & $\# 8$ & $17: 00$ & $27 / 06 / 2017$ & Catodo entrada & 5,76 & 6,5751 & 0,0000 & 24,7858 & 80,8534 & 11,2841 & 1718 & 21,3 & 7,3 & 271,85 & - \\
\hline 248 & $\# 8$ & $17: 00$ & $27 / 06 / 2017$ & Anodo entrada & 5,76 & 9,5489 & 0,0000 & 0,0000 & 65,8197 & 6,0337 & 1008 & 21,2 & 7,3 & 204,96 & - \\
\hline 249 & $\# 8$ & $17: 00$ & $27 / 06 / 2017$ & Anodo reator & 5,76 & 7,9274 & 0,8525 & 5,5567 & 49,5899 & 8,6537 & 1379 & 21,4 & 7,31 & 286,14 & - \\
\hline
\end{tabular}

